UNIVERSIDADE DE SÃO PAULO

Escola de Comunicações e Artes - ECA

JULIANA MONTEIRO

DOCUMENTAÇÃO EM MUSEUS E OBJETO-DOCUMENTO:

SOBRE NOÇÕES E PRÁTICAS

São Paulo

2014 


\author{
UNIVERSIDADE DE SÃO PAULO \\ Escola de Comunicações e Artes - ECA \\ Programa de Pós Graduação em Ciência da Informação
}

JULIANA MONTEIRO

\title{
DOCUMENTAÇÃO EM MUSEUS E OBJETO-DOCUMENTO: SOBRE NOÇÕES E PRÁTICAS
}
Dissertação para obtenção do título de mestre, apresentada ao Programa de Pós-Graduação em Ciência da Informação da Escola de Comunicações e Artes, da Universidade de São Paulo. Área de Concentração: Cultura e Informação. Linha de Pesquisa: Organização da Informação e do Conhecimento.

Orientadora: Profa. Dra. Marilda Lopes Ginez de Lara.

(Versão corrigida. O original se encontra disponível na biblioteca da ECA-USP)

São Paulo 
Autorizo a reprodução e divulgação total ou parcial deste trabalho, por qualquer meio convencional ou eletrônico, para fins de estudo e pesquisa, desde que citada a fonte.

Catalogação na Publicação Serviço de Biblioteca e Documentação

Escola de Comunicações e Artes da Universidade de São Paulo Dados fornecidos pelo(a) autor(a)

Monteiro, Juliana

Documentação em museus e objeto documento: sobre noções e práticas / Juliana Monteiro. -- São Paulo: J. Monteiro, 2014 .

177 p.: il.

Dissertação (Mestrado) - Programa de Pós-Graduação em Ciência da Informação - Escola de Comunicações e Artes / Universidade de São Paulo.

Orientadora: Marilda Lopes Ginez de Lara

Bibliografia

1. Documentação em museus 2. Objeto-documento 3. Ciência da Informação 4. Museologia 5. Documentação I. Lara, Marilda Lopes Ginez de II. Título.

CDD 21.ed. - o20 
Nome da autora: Juliana Monteiro.

Título: Documentação em museus e objeto-documento: sobre noções e práticas.

Dissertação para obtenção do título de mestre, apresentada ao Programa de Pós-Graduação em Ciência da Informação da Escola de Comunicações e Artes, da Universidade de São Paulo. Área de Concentração: Cultura e Informação. Linha de Pesquisa: Organização da Informação e do Conhecimento.

Aprovada em: de de 2014.

Presidente da banca:

\section{Banca Examinadora}

Profa. Dra. Marilda de Lopes Ginez de Lara Instituição: ECA-USP Julgamento:

Assinatura:

Profa. Dra. Maria de Fátima Gonçalves Tálamo Instituição: ECA-USP Julgamento: Assinatura: 
Para o Fabio, meu companheiro, meu par, minha luz, simplesmente por tudo.

E para minha mãe, Regina, por sua incansável fé na vida. 


\section{AGRADECIMENTOS}

À Profa. Marilda Lopes Ginez de Lara, pela orientação e pelas trocas, que muito colaboraram para abrir novos horizontes para a pesquisa.

Às Profas. Maria de Fátima Gonçalves Tálamo e Suely Moraes Ceravolo, da Banca de Qualificação, pelos comentários que foram muito importantes para o aprofundamento deste trabalho.

Aos meus amigos e colegas de profissão Cecília Machado e Gabriel Moore Forell Bevilacqua, por terem me mostrado o universo vibrante e complexo da documentação em museus. $E$ às minhas amigas Juliana Rodrigues Alves, Marcia Mattos e Raquel Jacob por terem me dado muito apoio para a conclusão desta dissertação.

À equipe da Unidade de Preservação do Patrimônio Museológico da Secretaria de Estado da Cultura de São Paulo, em particular nas pessoas de Claudinéli Moreira Ramos, Renata Vieira da Motta e Cristiane Batista Santana por sua grande generosidade, incentivo e compreensão para comigo e com este trabalho.

Aos meus colegas dos museus da Secretaria de Estado da Cultura de São Paulo, por terem sempre contribuído para a reflexão teórica e prática sobre o cotidiano, muitas vezes complexo, da gestão de acervos de museus.

Aos meus alunos do curso técnico de Museologia da ETEC Parque da Juventude/Centro Paula Souza, que sempre me colocaram questões novas e desafios práticos sobre o universo documentário dos museus.

À Ana Lucia Canton, por toda a atenção, apoio e lucidez na reta final deste trabalho.

Ao Francisley da Silva Dias, pelo trabalho de revisão. E à Carolina Vázquez, pelo apoio na redação do resumo em inglês.

À minha família, pelo carinho e estímulo.

E aos amigos queridos Paulo José Nascimento Lima e Luzia Gomes Ferreira, por nossas longas conversas sobre a Museologia e seus desafios, desde o tempo de São Lázaro. 


\section{RESUMO}

A presente pesquisa teve por objetivo geral analisar os usos dos termos documentação, documento e objeto no contexto da área de museus. Tal contexto foi caracterizado em dois universos: o teórico, da literatura selecionada de caráter teórico da Documentação, Ciência da Informação e a Museologia, e o prático, composto por duas normas da área de museus. Os objetivos de trabalhar com estes dois universos foram mapear, caracterizar e problematizar ideias, tensões e aproximações entre os universos da teoria e da prática, sem a pretensão de se chegar a uma definição unívoca dos mesmos. Para alcançar tais objetivos, optou-se por uma metodologia exploratória, descritiva, comparativa e que se valeu de elementos de pesquisa histórica. No que se refere aos procedimentos, se realizou essencialmente levantamento bibliográfico e uso de ficha de coleta terminológica para o termo documentação - apenas para sistematizar significados e não para propor uma definição unívoca. A comparação entre os usos dos termos estudados apresentam polissemia e certa ambiguidade e, no que se refere particularmente ao termo documentação, ainda há um discurso que reitera a ideia de sua vinculação com a questão do controle das coleções. Os resultados desta investigação reforçam que a diversidade de significados influencia fortemente o que se realiza na prática profissional. Além disso, os usos consolidam diferentes tradições e formas de se conceber documentação e objetos-documentos nos museus - o que deve ser cada vez mais pesquisado para reforçar laços e rever conceitos e procedimentos. Por último, vale destacar que o propósito deste trabalho foi de explorar as diferenças terminológicas, tão inerentes ao universo dos museus, e colocar questões de como operar com elas e a partir delas.

Palavras-chave: Documentação em museus. Normas para documentação em museus. Administração de coleções em museus. Acervos museológicos. 


\begin{abstract}
The present study aimed to analyze the general uses of the terms documentation, document and object within the context of the museums field. This context was characterized in two universes: the theoretical, represented by selected bibliography taken from Documentation, Information Science and Museology, and practical, consisting of two standards of museums area. The objectives of working with these two universes were to map, characterize and discuss ideas, approaches and tensions between the worlds of theory and practice, without the intention of getting any unique definition. In order to get those objectives, an exploratory, descriptive, comparative methodology was chosen, that also drew upon elements of historical research. As regards procedures, bibliographic record and use of terminological data collection form for the term documentation were used, and this last one was only to systematize meanings and not to elaborate a unified definition. The comparison between the uses of the terms being studied point out their polysemy and ambiguity and, in the case of term documentation, the idea of its connection with the control of the collections still remains. Results of this study also reinforce this diversity of meanings strongly influences what is done in professional practice. Furthermore, it consolidates different traditions and ways of conceiving documentation and objects-documents in museums - which should be increasingly researched to reinforce ties and review concepts and procedures. Finally, it is worth noting that the purpose of this study was to explore the terminological differences, so inherent to the universe of museums, and raise the issue of how to deal with them and from them.
\end{abstract}

Key-words: Museum documentation. Museum documentation standards. Museums collections management. Museological collections. 


\section{LISTA DE QUADROS}

Quadro 1 - Ocorrências do termo documentação na literatura da Museologia e da área de museus na Europa, Estados Unidos e Brasil, entre as décadas de 1950 e 2000

Quadro 2 - Grupos de informação da SPECTRUM com referências aos eixos de política de acervo 135

Quadro 3 - Grupos de informação CIDOC e suas finalidades 145 


\section{SUMÁRIO}

1. INTRODUÇÃO

2. A DOCUMENTAÇÃO: BASE CONCEITUAL DA CI E RELAÇÕES COM A MUSEOLOGIA

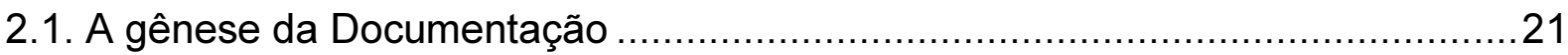

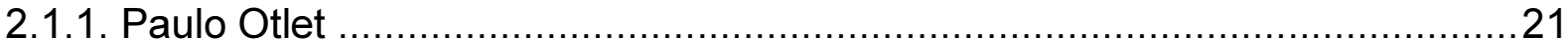

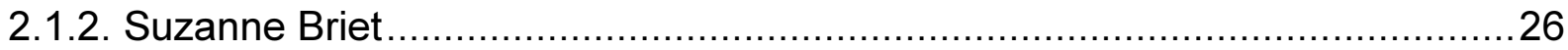

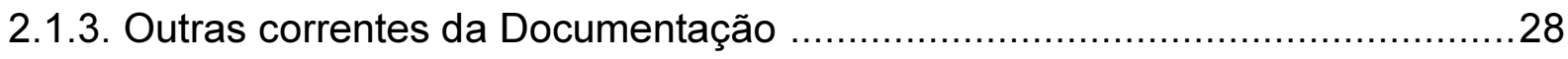

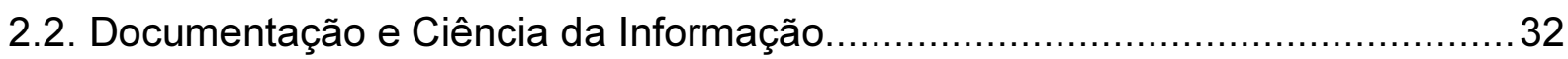

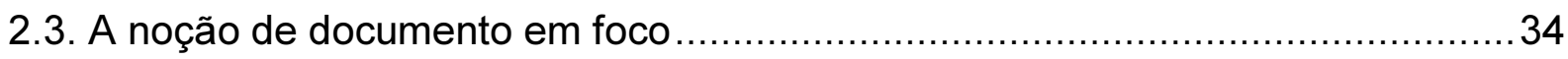

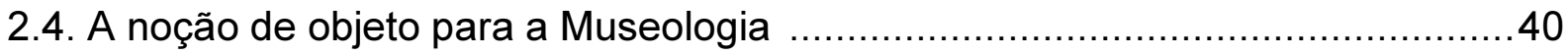

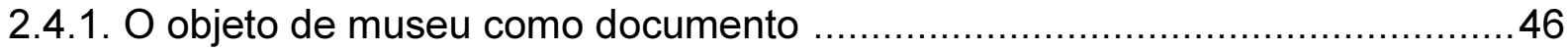

3. O TERMO DOCUMENTAÇÃO NO CONTEXTO DOS MUSEUS: POLISSEMIA E

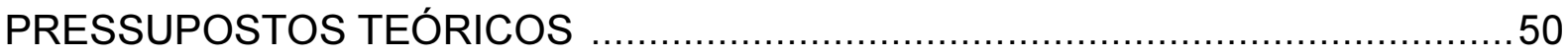

3.1. Apontamentos históricos sobre a documentação em museus ……...................53

3.1.1. Europa, século XVI ao XIX: do colecionismo privado ao surgimento dos

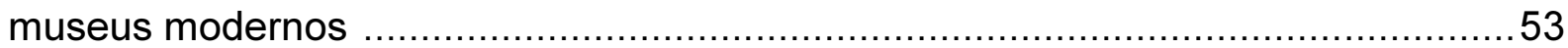

3.1.2. Século XX: surgimento das primeiras iniciativas internacionais ...................57

3.1.3. Europa: as experiências do Reino Unido e Espanha ...................................60

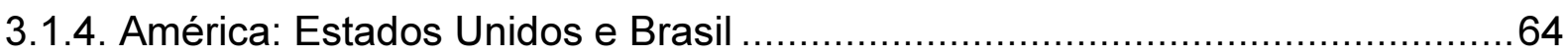

3.1.5. Considerações preliminares a partir dos apontamentos históricos .................71

3.2. Variações em torno do termo documentação no contexto dos museus ..............73

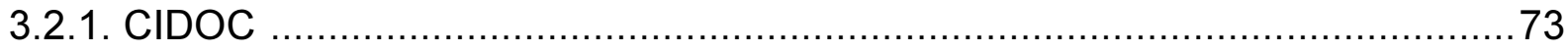

3.2.2. Reino Unido

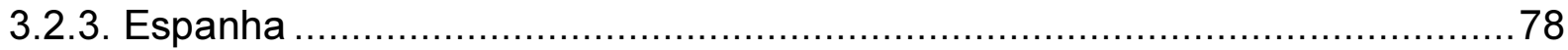

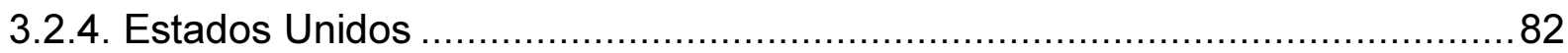

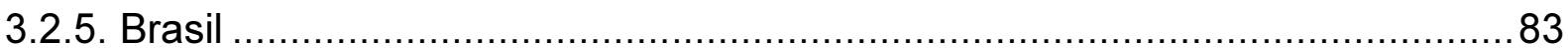

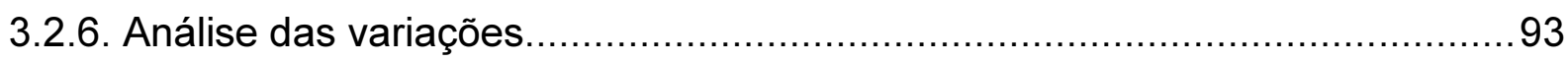


4. O OBJETO EMPÍRICO: ANÁLISE SOBRE USOS DOS TERMOS DOCUMENTAÇÃO E DOCUMENTO NA SPECTRUM E NAS INTERNATIONAL GUIDELINES OBJECT INFORMATION: THE CIDOC INFORMATION CATEGORIES

4.1. SPECTRUM - Standard Procedures for Collections Recording Used in Museums / The UK Museum Collections Management Standard (1994). 103

4.2. Apontamentos sobre a criação das International Guidelines Object Informations:

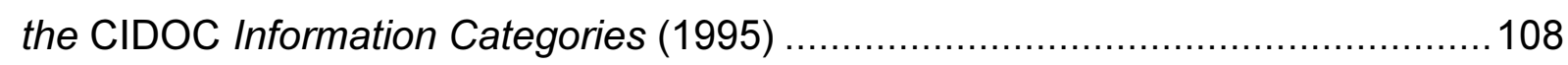

4.3. Análise das Diretrizes do CIDOC e da SPECTRUM ......................................112

4.3.1. Detalhamento de estrutura textual e de definições presentes na SPECTRUM 4.0 119

4.3.2. Detalhamento de estrutura textual e de definições presentes nas Diretrizes do CIDOC 139

4.4. Análise da SPECTRUM e das Diretrizes do CIDOC frente às discussões sobre objeto de museu como documento e documentação em museus 149

5. CONCLUSÕES 152

6. REFERÊNCIAS BIBLIOGRÁFICAS 159

ANEXO A - Ficha de coleta terminológica 169 


\section{INTRODUÇÃO}

O objetivo geral da pesquisa foi o de analisar os usos dos termos documentação e objeto-documento no contexto da área de museus em referências teóricas existentes sobre o tema e normas oriundas do universo da prática profissional, como desdobramento do objeto de pesquisa. A partir disso, um objetivo específico foi mapear o emprego de tais termos em dois contextos: o primeiro, composto pela literatura selecionada para pesquisa; o outro, prático, com o mapeamento dos usos dos termos nas International Guidelines Object Information: the CIDOC Information Categories, lançada pelo Comitê Internacional de Documentação do Conselho Internacional de Museus - CIDOC / ICOM - em 1995, e na norma SPECTRUM - Standard Procedures for Collections Recording Used in Museums / The UK Museum Collections Management Standard, lançada pela entidade britânica Collections Trust desde 1994. Devido às especificidades da norma, foi selecionado para o mapeamento especificamente seu Object Information Group.

O último objetivo específico foi um desdobramento do anterior: comparar os usos dos termos documentação e objeto-documento no contexto do ambientemuseu a partir dos elementos da teoria e da prática analisados, para identificar e extrair considerações sobre possíveis tendências e desdobramentos sobre o assunto. Sendo assim, a pesquisa pretendeu identificar os diferentes traços que caracterizam a aplicação dos termos citados, particularmente do termo documentação. Para isso, foram consideradas as variáveis de tempo e espaço na produção dos autores das referências teóricas e das normas, sem a pretensão de propor uma definição unívoca de documentação em museus ou de objetodocumento. A investigação abordou esse assunto a partir de uma perspectiva teórica interdisciplinar entre a Documentação, a Ciência da Informação e a Museologia, o que contribui para explorá-lo de forma mais ampla.

A inquietação em torno do que significa falar em documentação e objetodocumento em museus adveio de minha experiência profissional como museóloga da Unidade de Preservação do Patrimônio Museológico da Secretaria de Estado da Cultura de São Paulo. Em meu cotidiano de trabalho diário, estive e estou envolvida com as responsabilidades de lidar especificamente com as questões técnicas 
ligadas à gestão dos acervos de seus museus. A documentação foi, portanto, um desafio profissional desde o início, tendo em vista a diversidade de tipos de objetos, abordagens curatoriais e formas e níveis diferenciados de interpretação do ato de documentar, com as quais tive e tenho que conviver.

As dúvidas surgidas no âmbito profissional, levaram-me a buscar na teoria aquilo que a prática já referendava como algo estabelecido, ou a testar na prática o que a teoria recomendava. Nesses momentos, com o olhar de gestora, busquei entender as origens de determinadas abordagens para pensar em novas estratégias, ou simplesmente para esclarecer questões eminentemente práticas que permaneciam pouco claras.

Quando já no Programa de Pós-Graduação em Ciência da Informação da ECA-USP, a procura pela literatura levou as indagações naturalmente para um universo de autores não somente da Museologia - área da qual provenho - mas também de disciplinas da Documentação e Ciência da Informação, revelando novas facetas sobre o tema. Compreendeu-se, assim, que os termos documentação, objeto e documento são polissêmicos por natureza, não sendo seus usos restritos à área de museus. Entendi também que discutir os meandros dos usos das palavras documentação e objeto-documento na área de museus é adentrar um caminho que possui mais dúvidas do que certezas.

A partir desse ponto, o projeto de pesquisa de mestrado passou a ter contornos mais precisos. Deixou em segundo plano uma preocupação inicialmente focada em questões sobre descrição de objetos, para a necessidade de compreender as nuances de caráter terminológico em torno do que significa falar em documentação e objeto nos ambientes-museu nas relações entre a teoria e a prática.

Com a revisão do escopo da pesquisa, a partir principalmente das disciplinas cursadas, o trabalho foi redimensionado. A pesquisa não objetiva mais propor algo, mas antes analisar comparativamente as questões teóricas relativas ao que constitui o fazer documental nos museus. A redefinição do foco se deu por conta da necessidade de delimitar a pesquisa de forma a inseri-la adequadamente nos quadros referenciais teóricos da Ciência da Informação, da Documentação e da Museologia.

Dentre as dificuldades encontradas, a principal foi a adequação da presente pesquisa no âmbito das discussões teóricas da Ciência da Informação, tendo em 
vista que a atividade de documentação em museus não possui forte expressividade em termos de estudos preponderantes da área. Parte da literatura da Ciência da Informação que discute os museus não aprofunda as especificidades do trabalho de tratamento e organização da informação com acervos de natureza museológica, que são heterogêneos por princípio. Mesmo que vários autores admitam os museus e os objetos, quase sempre no sentido de objetos tridimensionais, como alvo da área, as discussões encontradas na literatura pouco avançam em proposição de metodologias, conceitos ou técnicas. O foco maior da Ciência da Informação, portanto, ainda é o texto, seja ele virtual ou impresso, ou a informação que se atrela à produção escrita.

Pelo lado da Museologia, a discussão também é lacunar, pois embora vários autores admitam a importância da documentação e considerem os objetos como documentos, não há proposições teóricas consolidadas em torno do tema. Além disso, nem sempre a articulação com os pressupostos da Ciência da Informação e a Documentação se faz presente. Verifica-se, também, carência de sistematização de noções basilares da Ciência da Informação e da Museologia, tendo em vista os próprios caminhos de estabelecimento dos campos nocionais de ambas, o que se mostra como uma dificuldade constante para o desenvolvimento da pesquisa.

Mais um fator a ser comentado é a localização e o acesso às fontes bibliográficas. Muita da produção existente sobre a discussão teórica em torno da documentação no contexto dos museus e do conceito de objeto museológico encontra-se dispersa. Às vezes, ainda que se encontre a referência de uma obra importante, a mesma não está disponível para consulta. É o caso da obra seminal de Yvonne Oddon, Elements de documentation museographique, lançada em 1968: localiza-se apenas versão preliminar, disponível para download, publicada na revista Museum da UNESCO, no mesmo ano. É o caso também do Traité de Documentation de Paul Otlet, cuja versão traduzida para o espanhol só possui um exemplar na biblioteca da ECA-USP, tornando a consulta bastante difícil.

Vários artigos citados pelos autores consultados nos capítulos segundo e terceiro, os quais poderiam colaborar com outras visões sobre o tema, também não puderam ser encontrados para consulta on-line, tendo em vista que muitas vezes as revistas onde foram publicados não os disponibilizam gratuitamente para todos os interessados ,ou ainda não possuem todas as suas edições digitalizadas. 
Em termos de base teórica, o trabalho se apoiou em três pressupostos teóricos centrais para o trabalho: o primeiro advindo da Museologia é a própria definição de objeto como testemunho, que possui faceta documental criada a partir do trabalho de musealização, que envolve também o fazer documental; o segundo, que se relaciona imediatamente ao primeiro, é a noção de documento conforme estabelecido pela Documentação, noção esta importante porque a Documentação, conforme concebida por Paul Otlet e Henri La Fontaine, entre o final do século XIX e início do $\mathrm{XX}$, estabelece que os objetos de um museu podem ser compreendidos também como documentos, em uma concepção alargada do mesmo. Tal entendimento, apesar de incorporado ao referencial teórico da Museologia, por ela ainda não foi plenamente desenvolvido. O terceiro pressuposto central desta dissertação procede da área da Ciência da Informação e pode ser considerado como herança das discussões realizadas no âmbito direto da Documentação. Resume-se à compreensão do documento como algo que se constrói e reconstrói a depender dos contextos informacionais, sociais, tecnológicos, institucionais e culturais envolvidos. Sendo assim, as práticas documentárias institucionalizadas, ou o fazer documental, possuem papel fundamental nesse processo de definição do potencial informativo que caracteriza o documento, logo, na definição do que é um documento em dado contexto.

Tal compreensão é particularmente pertinente para estabelecer uma crítica ao contexto dos museus, em que as operações de documentação, e consequentemente os atores por trás das mesmas, nem sempre são problematizados como fatores de influências determinantes para a significação e difusão dos acervos junto ao público de uma instituição. Apesar disso, ainda é lacunar a abordagem que a Ciência da Informação realiza dos processos informativos e documentais que ocorrem dentro dos museus, o que reforça a pertinência da abordagem interdisciplinar do problema de pesquisa. Sendo assim, a comparação e análise dos usos dos termos documentação e objeto-documento na área de museus justificam-se pela importância de se reconhecer, detalhar e interpretar as singularidades de cada uso dentro de seus contextos. Diz-se isso tendo em vista a possibilidade que um estudo dessa natureza oferece para auxiliar o reconhecimento de características, lacunas e limites sobre o ato de conceber os objetos de museu e documentação em museus, e fazer documentação com esses objetos-documentos. 
Diante do exposto, o problema da pesquisa pode ser resumido às seguintes questões: o que significa, afinal, tantas diferenças em torno das ideias de documentação e objeto-documento no contexto dos museus? O que um autor norteamericano denomina como registration, por exemplo, será o mesmo que um autor brasileiro denomina como documentação museológica? Estão os autores falando sobre os mesmos conceitos e a mesma prática profissional? E quais aproximações ou distanciamentos existem na relação entre teoria e prática sobre objeto de museu e documentação em museus, quando abordadas a partir da Documentação, Ciência da Informação e Museologia?

Para a realização dos objetivos estabelecidos e perante a justificativa para a pesquisa, a metodologia adotada foi exploratória, descritiva e comparativa, se valendo de elementos de pesquisa histórica. Adotou-se também uma metodologia mista, interdisciplinar e combinatória, a fim de que o objeto de estudo fosse compreendido em suas nuances, tal como se realizam contemporaneamente as abordagens no âmbito das Ciências Sociais e Humanas. Essa abordagem também permite que a crítica feita seja interna ao seu contexto histórico de produção, de modo a identificar possíveis tendências, conceitos, aproximações e tensões com os referenciais teóricos das áreas da Museologia, Ciência da Informação e Documentação.

Em termos procedimentais, a pesquisa se valeu de levantamento bibliográfico, a partir de critérios pré-determinados para a caracterização da literatura selecionada, e que compôs o aspecto teórico da pesquisa. A partir de tais critérios, foi possível escolher autores vinculados a organismos de caráter internacional como o CIDOC, ou oriundos do Reino Unido, Espanha, Estados Unidos e Brasil, que produziram textos ou livros de referência sobre o assunto entre 1950 e 2000. Para análise particular do uso do termo documentação de tais autores, foi utilizada uma ficha de coleta terminológica, usada exclusivamente para efeito de sistematização. $O$ foco no termo citado se deu porque o mesmo, quando ocorre nos textos, geralmente traz consigo os termos objeto e documento, permitindo também a análise subsequente de seus usos.

As normas do CIDOC e do Collections Trust foram analisadas a partir de uma série de categorias que permitem criar pontos de comparabilidade entre elas. Os termos objeto, documento e documentação, quando existentes nas normas, também foram incorporados à ficha de coleta terminológica citada. É importante ressaltar que 
os modelos pesquisados foram selecionados seguindo os seguintes critérios: a) suas criações por instituições que lidam por sua própria natureza com diferentes museus e acervos ao mesmo tempo, como órgãos internacionais, de representação profissional, ou órgãos públicos da área de museus; b) suas estruturas construídas para serem aplicadas em diferentes contextos e c) seus reconhecidos usos por vários museus e entidades da área ao redor do mundo.

A pertinência de focar normas e diretrizes está no fato de que elas são, em sua maioria, propostas validadas pela comunidade profissional e amplamente usadas em vários contextos institucionais. Suas estruturações e conceitos, ou definições, presumem um nível mínimo de reflexão por parte de seus autores, o que permite analisar suas conexões com a produção teórica sobre o assunto. Elas demonstram, tanto quanto a produção literária sobre o tema documentação em museus, que o mesmo se encontra cada vez mais em evidência, reforçando a necessidade da construção de novas abordagens, metodologias e pressupostos a seu respeito.

Para parametrizar tal discussão, o tema é debatido nesta dissertação em três capítulos. Após essa introdução, o capítulo 2 aborda a discussão da Documentação enquanto disciplina, examinando a noção de documento gerada no âmbito dessa disciplina e de sua compreensão como base para a Ciência da Informação e para o debate da Museologia sobre os objetos-documentos. O objetivo é circunscrever a Documentação para demarcar as similaridades e tensões com o que se convencionou chamar de documentação no contexto dos museus. Para abordar tais problemáticas, nesse capítulo são referenciados autores que discutem a Documentação como disciplina de base para a Ciência da Informação e suas interfaces possíveis com a Museologia. Para caracterização da área de Documentação, descrevemos sua história e sua noção de documento. Nesse contexto, a noção de documento é considerada uma das principais definições legadas para a Ciência da Informação, com potencialidade de contribuir para a revisão da definição de objeto como documento para a Museologia. Para essa revisão são utilizados textos de Briet (2006), Frohmann (2008), Ortega (2009), Rayward (1997), Tálamo e Smit (2007). Do mesmo modo, examinamos as contribuições de autores da Ciência da Informação que se dedicam a abordagens críticas da noção de documento, ou realizam revisões históricas sobre o termo, como Buckland (1997), Lara e Ortega (2009, 2011), Lund (2009) e Smit (2008). Tal 
análise também demanda contribuições de autores que discutem o conceito de objeto de museu, como Castro (2009), Ceravolo (2009), Desvallés e Mairresse (2010), Guarnieri (1990), Meneses (1994) e Mensch (1992), entre outros.

O capítulo 3 trata da documentação no contexto dos museus. Nele, é realizada uma contextualização do desenvolvimento da atividade documental no universo dos museus, a qual tem como base a comparação entre as variações encontradas na produção acadêmica de autores que se dedicam ao assunto, originários das áreas da Documentação, Ciência da Informação e, majoritariamente, da Museologia. Como já dito, a comparação possui dois objetivos: identificar traços das diferentes definições de documentação no contexto dos museus e verificar as leituras possíveis a partir dos traços identificados, tendo em vista o quadro referencial teórico do capítulo 2.

Devido à necessidade de delimitação da variável espacial para a comparação, foram selecionados autores que produzem no âmago de uma perspectiva internacionalizante como a do CIDOC, Reino Unido, Espanha, Estados Unidos e Brasil. No caso do CIDOC, ele foi selecionado por ser a primeira iniciativa internacional sobre o assunto documentação na área de museus a ganhar maior projeção e sistematização, ainda que em seus primeiros anos fosse mais restrito ao universo europeu. Os países da Europa citados e Estados Unidos foram selecionados por serem centros de produção sobre o assunto, particularmente o Reino Unido, que é o contexto espacial de um das referências da prática profissional analisados neste trabalho. No caso do Brasil, o mesmo foi selecionado por ser o contexto de origem da presente pesquisa, o que permite fazer contrapontos teóricos importantes e necessários com os outros.

A abordagem teórica da noção de documentação em museus baseia-se primeiramente em autores que procuram definir o que é documentação no contexto dessas instituições. Entre eles estão Marín Torres (2002), para quem a documentação de museus é herdeira das atividades pensadas por Paul Otlet ao iniciar o movimento da Documentação, localizando o início do uso do termo na área museológica a partir da década de 1950, com a criação do CIDOC. Para avanço da compreensão sobre os contextos de desenvolvimento da documentação de acervos de museus, utilizamos também textos de autores como Novaes (2000), Oddon (1968), Olcina (1970) e Riviére (1993). Para compreensão das variantes semânticas e das perspectivas teóricas e metodológicas a elas subjacentes, foram utilizados 
textos fundamentalmente de Bakhtin (2004), Ceravolo (1998, 2000, 2004, 2012) e, novamente, Marín Torres (2002). Para detalhamento sobre as características fundamentais da documentação realizada nos museus, foram utilizados autores como Bottallo (2000), Ferrez (1991) e Gutiérrez Usillos (2010). Objetivou-se que tal revisão das variações levasse, consequentemente, à configuração de um panorama inicial de discussão sobre o que é documentação no contexto dos museus e quais são os seus traços fundamentais.

O capítulo 4 é dedicado ao estudo do objeto empírico da pesquisa, a saber: as International Guidelines Object Information: the CIDOC Information Categories (1995) e o Object Information Group da SPECTRUM - Standard Procedures for Collections Recording Used in Museums - The UK Museum Collections Management Standard, versão 4.0 (2011b). A proposta é contextualizar brevemente a produção de cada um dos modelos indicados, a fim de caracterizar seus discursos, conceitos e formas subjacentes, ou não, de abordagem sobre a documentação em museus e os objetos de museu. Nesse capítulo, realiza-se um breve histórico dos dois modelos de referência escolhidos, e, na sequência, cada modelo é detalhado na sua estrutura, a fim de verificar suas respectivas definições de documentação e objeto. Objetiva-se conhecer as estruturas e conceitos que subsidiam os elementos do objeto empírico, de modo a realizar sua análise a partir do cenário teórico construído nos dois capítulos anteriores. A análise comparativa entre as categorias de informação indicadas nos dois modelos é feita a partir do quadro referencial teórico construído pelos dois capítulos anteriores.

Como são modelos utilizados por diferentes museus, nas conclusões procuramos propor uma visão sobre como tais propostas podem contribuir, ou não, para uma nova abordagem e operacionalização da documentação em museus. Procura-se nesse ponto do trabalho também pontuar e analisar comparativamente os contrastes e convergências entre prática e teoria no que se refere ao tema documentação em museus, a partir das principais questões conceituais levantadas nos capítulos anteriores.

Por último, vale ressaltar que o enquadramento desta pesquisa no Programa de Pós-Graduação em Ciência da Informação da ECA-USP, na Linha de Pesquisa Organização da Informação e do Conhecimento, se dá justamente pelo objetivo de realizar uma abordagem comparativa e histórica sobre questões terminológicas relacionadas à documentação para museus, com a finalidade de identificar 
estruturas conceituais, tendências e formas de relacionamento com práticas institucionais.

Diante dos desafios do relacionamento entre teoria e prática nas questões relativas à documentação em museus e aos objetos-documentos de museu, esperamos que esta dissertação contribua para o aprofundamento do conhecimento teórico sobre o tema, de suas lacunas e necessidades de avanço metodológico. Do mesmo modo, que também colabore na aproximação entre as áreas da Museologia, Ciência da Informação e Documentação, a partir de um diálogo que se julga imprescindível para o aprofundamento teórico-metodológico da documentação em museus, com suas tensões, sobreposições e consensos possíveis entre diferentes disciplinas envolvidas, tal como se mostra a natureza da linguagem. 


\section{A DOCUMENTAÇÃO: BASE CONCEITUAL DA CI E RELAÇÕES COM A MUSEOLOGIA}

O foco deste segundo capítulo é analisar a Documentação enquanto disciplina fundada no final do século XIX, estabelecida no início do século XX na Europa, influenciando o que hoje se denomina Ciência da Informação. Considera-se que sua contribuição para esta pesquisa esteja na noção central de documento, estabelecendo-se como um elemento para a construção de interfaces com a Museologia.

A preocupação com a caracterização da Documentação no contexto deste trabalho é derivada da necessidade de compreender seus pressupostos, enfoques e conceitos, a fim de verificar as aproximações e tensões com o que se entende no contexto dos museus e da Museologia como documentação. Tais referências também fornecem um ponto de partida para observação de como pressupostos centrais da Documentação - a exemplo da ampliação do conceito de documento, que passou a considerar inclusive objetos de museu - foram desenvolvidos pela Ciência da Informação (Cl) e pela Museologia, principalmente na sua dimensão prática.

Para efeito de distinção entre os termos homógrafos, quando a referência do termo for ao movimento concebido por Paul Otlet e Henri La Fontaine no final do século XIX e que teve entre seus discípulos Suzanne Briet, será mantida a grafia 'Documentação', como já convencionado na bibliografia. Por outro lado, quando a referência for o conjunto de atividades de caráter documentário realizado nos museus para tratar suas coleções, a grafia mantida será 'documentação'.

A primeira parte deste capítulo é dedicada ao maior detalhamento da disciplina Documentação, a fim de apresentar o pensamento de seus fundadores Paul Otlet e Henri La Fontaine, e de sua discípula principal, Suzanne Briet. Também serão abordados outros autores que representam as etapas posteriores de desenvolvimento da Documentação para caracterização das tendências ou correntes. Será caracterizada a noção de documento, tida como central para a Documentação e para a própria Ciência da Informação. Na segunda parte, a partir da caracterização da noção central de documento para a Documentação, será abordada a noção de objeto museológico. Quais são as características possíveis 
que esse termo encerra? E o que implica essa qualificação? Essas são perguntas que nortearão a primeira parte da revisão bibliográfica, focada no repertório teórico da Museologia. Posteriormente, será realizada uma crítica à ideia de objeto museológico como documento, a partir das semelhanças e diferenças que as duas noções possuem entre si. Desse modo, pretende-se subsidiar a discussão que acontecerá no terceiro capítulo, relativa à apropriação do termo "documentação" quando aplicado no contexto dos museus e da Museologia.

\subsection{A Gênese da documentação}

\subsubsection{Paul Otlet}

A Documentação teve como fundadores dois advogados belgas, Paul Otlet $\mathrm{e}$ Henri La Fontaine. Sua constituição como disciplina data do final do século XIX (TÁLAMO; SMIT, 2007), quando ambos iniciaram sua atuação profissional na organização do que era então julgado como a explosão informacional do conhecimento humano registrado em diferentes formatos, não mais restritos ao livro. Vale destacar que a preocupação, particularmente de Paul Otlet, em torno da criação de normativas que permitissem o acesso universal ao conteúdo informativo recai em um espírito pacifista, característico do pós Primeira Guerra Mundial, período no qual as principais obras do advogado são lançadas.

Outro aspecto acerca da natureza da concepção otletiana da Documentação também merece atenção, a fim de se entender melhor os pressupostos e definições por ela difundidos. A produção de Otlet pode ser interpretada como sui generis porque se insere, ao mesmo tempo, entre dois polos: de um lado, o desejo de disponibilização universal de informação, de modo a facilitar o diálogo entre as pessoas e as nações; de outro, a firme percepção racional e enciclopédica do mundo, tendo em vista o entendimento de que apenas um único padrão de classificação e organização da informação seria a saída para o acesso pleno à informação, como se todas as pessoas pudessem ter uma única forma de apreensão da informação (TÁLAMO; SMIT, 2007).

Conforme explicam Tálamo e Smit (2007, p. 46-47): 


\begin{abstract}
A Documentação aproxima-se da matriz do pensamento da modernidade pelo rigor e critérios metodológicos, mas dela se distancia pelo valor dado ao conhecimento, o que em certa medida justifica a qualificação de visionário atribuída a Otlet (RAYWARD, 1997; RIEUSSET-LEMARIÉ, 1997 apud TÁLAMO; SMIT, 2007, p.46-47).
\end{abstract}

Rayward (1997) também considera que as ideias de Paul Otlet podem ser consideradas precursoras de várias iniciativas que caracterizam os problemas centrais da $\mathrm{Cl}$ na contemporaneidade, como a preocupação com o uso da tecnologia, da linguagem na recuperação da informação, da existência dos hipertextos, da própria internet e das estruturas sociais que existem em torno da organização do conhecimento e da informação. Otlet anteviu também a incorporação das práticas de organização de acervos de arquivos, bibliotecas, museus e instituições semelhantes a uma área maior, a Documentação. Porém, o mesmo autor chama a atenção para que não sejam imputados à Otlet conceitos e ideias estranhos à sua produção, ou ao seu contexto histórico. Nesse sentido, destaca que é preciso reconhecer o aspecto positivista do raciocínio de Otlet, que seria posteriormente rebatido pelos autores responsáveis pelo desenvolvimento da própria Documentação e da $\mathrm{Cl}$, como será apresentado a seguir. Qualquer análise feita sobre suas contribuições para áreas como a Ciência da Informação e até para a documentação em museus deve, portanto, levar essa questão em consideração.

Sobre a definição do que é a Documentação, Ortega (2009) explica que Otlet passou a utilizar o termo em 1905, ao publicar seu artigo L'organisation rationalle de l'information et de la documentation en matière economique. Para a autora, esse teria sido o primeiro momento de uso das palavras informação e documentação na obra de Otlet. Vale ressaltar que, conforme destaca a mesma autora, o próprio Otlet não manteve uma aplicação unívoca do termo, sendo possível identificar contradições ou ambiguidades a esse respeito na sua produção literária.

Em sequência, 1905 e 1917, Otlet abandonou o uso da palavra bibliografia para usar cada vez mais as palavras documentação e informação, muito embora as considerasse equivalentes e usasse umas pelas outras (ORTEGA, 2009). No caso da obra mais conhecida de Otlet, o Traité de Documentation - ou Tratado de Documentação -, publicado em 1934, Ortega (2009) destaca o emprego da palavra "Documentologia" para identificar uma nova área de conhecimento, que ultrapassaria as técnicas pouco adequadas da bibliografia, biblioteconomia e da própria documentação. Otlet entende que a Documentologia seria a área que 
estabeleceria novas formas de prover acesso a toda massa de informação incoerente que vinha sendo produzida por diversas fontes.

Tálamo e Smit (2007) destacam que é no Traitè que Otlet estabelece os oito princípios da Documentação. Na opinião das autoras, esses oito princípios são os principais elementos do pensamento otletiano, os quais rompem com a modernidade ao enfatizar a importância do acesso à informação em detrimento à sua utilidade ${ }^{1}$. A Documentação partia do pressuposto de prover acesso às informações documentadas sobre quaisquer coisas que existissem, e deveriam ser:

1. Universais quanto ao seu objeto;

2. Confiáveis e verdadeiras;

3. Completas;

4. Rápidas;

5. Atualizadas;

6. Fáceis de obter;

7. Anteriormente reunidas e prontas para serem comunicadas;

8. Colocadas à disposição do maior número de pessoas.

Para alcançar todas essas características da informação oferecida, Paul Otlet (1934) entreviu a execução de métodos, códigos de classificação e técnicas específicas. Em conjunto com Henri La Fontaine, propôs, entre outras ações, a criação do Repertório Bibliográfico Universal - RBU -, com objetivo de repertoriar todas as obras publicadas desde o início da imprensa, através da cooperação entre

\footnotetext{
${ }^{1}$ A esse respeito, vale ressaltar a explicação de Oliveira (2001) acerca do pensamento moderno, calcado na consolidação do método científico. A história da criação do método científico remonta aos séculos XVI e XVII, e aos diferentes movimentos políticos, econômicos e sociais que levaram à desestabilização da forma de conhecimento contemplativa, ou teocêntrica, característica da idade medieval. Nesses períodos que culminaram na criação do positivismo no século XIX, o cientista, o homem do conhecimento, era entendido como propulsor de uma ciência de intervenção, que propunha a decomposição do real em partes para delas extrair conhecimentos precisos, utilitários, objetivos e com natureza de leis universais. Esse atrelamento da questão do método aos projetos de interferência ou modificação social é, segundo o autor, possível de ser entendido como parte de um contexto onde um projeto europeu, burguês e capitalista de sociedade se estabeleceu como parâmetro para as ciências. Contudo, no esteio do desenvolvimento do discurso científico positivista do século XIX já surgiriam vozes que chamariam a atenção para o fato de que o ser humano é, nos estudos sociais, sujeito e objeto de conhecimento, cujos comportamentos, reações e relações não são estáticas e nem passíveis de serem totalmente padronizadas a partir de uma perspectiva empírica. Aqui, Oliveira (2001) destaca que, ao se pensar nas ciências humanas como um todo, não se trata de destituir o olhar crítico do pesquisador, mas ter a certeza de que o real não é algo que pode ser unilateralmente interpretado e representado.
} 
os países. O objetivo do RBU era criar um catálogo universal com classificação sistemática de toda produção bibliográfica universal.

Outro desses elementos, e cuja concepção também antecede o próprio Traité, é a Classificação Decimal Universal -CDU -, derivada da revisão da Classificação Decimal de Dewey efetuada pelos advogados belgas no contexto do amplo projeto do Repertório Bibliográfico Universal (RAYWARD, 1997). A Classificação foi estruturada por Otlet e La Fontaine com a finalidade de relacionar as publicações, de modo a associar a organização física dos documentos com acesso ao conteúdo dos mesmos, através da atribuição de notações específicas. O objetivo era, por meio de uma classificação cuja ênfase residia na síntese de características comuns dos assuntos e sua codificação em números, facilitar e tornar mais ágil a identificação e o acesso aos documentos.

Outro elemento fundamental da concepção otletiana sobre a Documentação é o princípio monográfico, que consistia na operação de extrair unidades de informação dos documentos originais e inseri-las em cartões específicos para consulta. O RBU, a CDU e o princípio monográfico foram desenvolvidos por Otlet e La Fontaine para operacionalizar as atividades do Instituto Internacional de Bibliografia / Federação Internacional para Informação e Documentação, criado no final do século XIX, na Bélgica. Tratava-se de uma operação de redução de complexidade de um documento aos seus elementos básicos, ou, no dizer de Rayward (1997), de dissecação ou decomposição de conteúdo dos documentos. Posteriormente, esses cartões poderiam ser reintegrados a outros repertórios, em uma dialética enciclopédica de interpretação. Nessa perspectiva, Otlet atribuía o foco da ação à identificação da ideia por trás do conteúdo da informação, se esquecendo das particularidades da criação autoral da mesma (RAYWARD, 1997).

Desse modo, é possível dizer que Paul Otlet concebeu a Documentação como a técnica adequada para tratar racionalmente os documentos de maneira a disponibilizar informações para quaisquer pessoas, em qualquer lugar do mundo (OTLET, 1937). Para ele, a organização do conhecimento humano já não mais podia ficar restrita às normativas da 'antiga Biblioteconomia' (OTLET, 1934). Para ele, essa era uma disciplina mais focada na gestão de acervos bibliográficos e menos no provimento de acesso, enquanto a Documentação viria justamente para ser um contraponto a ela. 
Três anos depois da publicação do Traité, em texto preparado para abertura dos trabalhos da Conferência Universal de Documentação, Otlet volta a utilizar novamente o termo Documentação e apresenta uma descrição da mesma como uma técnica marcada por uma organização em sistema, que:

é constituída por uma série de operações distribuídas, hoje, entre pessoas e
organismos diferentes. O autor, o copista, o impressor, o editor, o livreiro, o
bibliotecário, o documentador, o bibliógrafo, o crítico, o analista, o
compilador, o leitor, o pesquisador, o trabalhador intelectual. A
Documentação acompanha o documento desde o instante em que ele surge
da pena do autor até o momento em que impressiona o cérebro do leitor.
(OTLET, 1937, s/p)

Com essa descrição, Otlet introduz a ideia de fluxo documentário - com diversas etapas e agentes sociais envolvidos na produção e disponibilização da informação. Tal concepção seria posteriormente desenvolvida por seus seguidores (ORTEGA, 2009) e pode ser considerada como uma das mais importantes contribuições do pensamento otletiano para a Ciência da Informação. Ressalta-se esse aspecto do trabalho de Otlet, devido ao fato dele colocar em primeiro plano a importância dos profissionais na organização da informação e o seu impacto na recuperação da informação pelos leitores.

Rayward (1996, 1997) ainda destaca que o entendimento de Otlet sobre a Documentação foi, inclusive, muito mais abrangente que o de muitos profissionais que se denominavam documentalistas apresentados em períodos antes e pós Segunda Guerra Mundial. Um dos principais destaques do pensamento otletiano era justamente a concepção ampla a respeito da noção de documento, que poderia ser qualquer coisa que possuísse significado - incluindo livros, jornais, filmes, fotografias, mapas e objetos de museu. Incluem-se nessa concepção os textos impressos, imagens, gráficos, representações esquemáticas, e mesmo objetos de museu (RAYWARD, 1996). Desse modo, Otlet ultrapassou a tradicional convenção que tinha apenas o livro como sinônimo de documento e as bibliotecas como lugares de conhecimento e informação. Sua preocupação central residia na organização das fontes de conhecimento, independente de seu suporte - muito embora seja necessário reconhecer, como também destaca Rayward (1997), a forte orientação de Otlet e seus seguidos posteriores para o tratamento somente de documentos textuais. 
Após a morte de Paul Otlet, a Documentação ganhou novos adeptos e críticos fervorosos. Ortega (2009) destaca que devido à ambiguidade da palavra, o desenvolvimento posterior da área conheceu diversas experiências de interpretação dos enunciados de Paul Otlet. A esse respeito, a autora destaca as discussões em torno do assunto em países como a França, que teve amplo protagonismo no desenvolvimento da Documentação, e também Espanha, Portugal, Estados Unidos e Brasil. Nesses países é possível observar a existência de compreensões diferentes acerca da definição de Documentação e do seu papel em relação à Ciência da Informação, como será apresentado na sequência.

\subsubsection{Suzanne Briet}

Uma das discípulas diretas de Otlet foi a documentalista francesa Suzanne Briet. Vale salientar que ao mesmo tempo em que é reconhecida como tal, Briet se afasta dos ideais pacifistas de Otlet, ao considerar a informação como insumo, algo que deve ter uma utilidade que a justifique, e que por isso se torna primordial para o avanço das relações de produção econômica (DAY, 2006). Para Ortega (2009), isso insere Briet entre a utopia de Paul Otlet e a cibernética emergente nos Estados Unidos, cuja corrida armamentista e científica com a União Soviética marca o contexto global do pós Segunda Guerra Mundial.

Para Briet (2006), apesar de a Documentação ter se estabelecido inicialmente no âmbito da pesquisa científica, ela se renova dentro de intervalos curtos de tempo. Conforme destaca a autora, a Documentação é um fator de produtividade. Aqui se observa a forte vinculação das técnicas indicadas para organização do conhecimento e da informação com a indústria, o que é também ressaltado por Saracevic (1997).

Em sua obra seminal, Qu'est-ce que la documentation?, publicada em 1951, o documento é todo signo concreto ou simbólico, registrado e preservado, de reconstituição ou de prova de um fenômeno físico ou intelectual. Briet também chamou a atenção para a existência de outro tipo de documento, aquele criado por meio das práticas documentárias, a partir das quais poderiam ser gerados novos documentos; documentos secundários, para representar o documento original, facilitando sua difusão. 
Para Briet (2006), a Documentação é uma técnica cultural necessária para organizar a informação científica. Para ela, a Documentação é composta por procedimentos de seleção, análise, descrição e tradução de conteúdos, com a finalidade primeira de elaborar produtos documentários - catálogos, índices, etc. Tais produtos, ou documentos secundários, gerados a partir da atividade documentária, devem ser conservados e sua utilização será determinada por algumas técnicas as quais Briet (2006) considera possíveis de serem aplicadas a quaisquer outros documentos. A Documentação ganha, assim, um caráter fortemente mediador entre a massa de informações em expansão e os usuários especialistas que necessitam acessá-la. Ao traçar o perfil profissional do documentalista, Briet (2006) esclarece que ele deve sempre estar nas fronteiras das áreas de base das instituições onde atuam, e ter como alvo de sua atuação a comunidade científica. Cabe a esse profissional a prospecção constante das novas informações e avanços da área de expertise na qual trabalha, acrescentando outro sentido para a preservação.

De maneira semelhante a Paul Otlet, Briet (2006) também aponta para a necessidade do documentalista agregar funções e saberes de profissionais anteriores, como a de bibliotecário, arquivista e curador de museu. Mas alerta para o fato de que tais profissões e suas técnicas correspondentes, isoladamente, já não dão mais suporte para a realidade informacional vivida naquele período, o que consolida o caráter inovador e particular da profissão de documentalista. É responsabilidade desse profissional, segundo a autora, manter-se atualizado com as novas técnicas, teorias e paradigmas das áreas, a fim de poder realizar as diversas atividades de processamento da informação e prover o acesso àqueles que realizam pesquisas científicas. Dessa forma, o documentalista não se subordina ao pesquisador científico, mas se encontra pareado e interligado a ele, embora em universos distintos de atuação.

É possível destacar na produção de Briet o reconhecimento de que a transformação de algo em documento é o que poderia justamente levar um objeto que não foi produzido com a finalidade de ser suporte de uma mensagem. Para ela, a informação sobre o objeto se constrói a partir de um novo olhar, o olhar de quem o usa como documento e não somente de quem o produziu. Um novo sentido para o documento pode ser dado a cada nova leitura, atribuição ou uso que se dá para ele. 
A função de informar do documento pode mudar ao longo dos anos e dos sujeitos que o utilizam.

\subsubsection{Outras correntes da Documentação}

Conforme explicam Ortega (2009), Lara e Ortega (2011) e Lund (2009), os autores que se sucederam a Suzanne Briet eram de países onde a Documentação se consolidou como disciplina dominante para estudos das questões da informação, tais como França e Espanha. Eles fizeram acréscimos importantes a essa discussão, focando muitas vezes suas pesquisas em torno da noção de documento e do estabelecimento de procedimentos e metodologias para sua recuperação.

Segundo Ortega (2009), a Documentação surgiu com força nos Estados Unidos nos anos de 1950, embora rapidamente tenha sido substituída pela Biblioteconomia Especializada e, na sequência, pela Ciência da Informação. A autora cita Estivals (apud LÓPEZ YEPES, 1995, p. 77) para explicar que a obra de Paul Otlet seria praticamente esquecida nesse país entre 1945 e 1965, contrariamente ao que ocorreu na Europa no mesmo período.

Segundo Lara e Ortega (2011) e Lund (2009), a questão da definição do que seria um documento - ou o que tornaria algo em documento - ganhou vulto na década de 1970, apesar de ainda bastante centrada na questão do texto/documento impresso. Para Ortega (2009), na França, a palavra Documentação ficou mais conhecida como sinônimo de um conjunto de métodos e técnicas, que se diferencia da Ciência da Informação, mais focada em resolver questões ligadas ao estudo das mídias e aos estudos culturais. Na Espanha, Ortega (2009, p. 13) explica que:

\footnotetext{
Ainda que o termo Documentación seja o mais amplamente utilizado e reconhecido para denominar a pesquisa, o ensino e a prática profissional, a expressão Ciencias de la Documentación é usada desde os anos 1970 (LÓPEZ YEPES, 1978) e início dos anos 1980 (CURRÁS, 1982) no sentido do conjunto das disciplinas documentárias que estudam e executam os diversos aspectos do processo documentário (LÓPEZ YEPES, 1995, p. 321 apud ORTEGA, 2009, p.13).
}

Apesar da variação em torno da apreensão do que é Documentação, Ortega (2009) explica ainda que na Espanha o desenvolvimento histórico da disciplina se deu a partir da profunda influência da obra de Paul Otlet. Mas nem por isso os autores que participaram de tal desenvolvimento deixaram de adotar uma 
interpretação própria dos enunciados otletianos e criar uma abordagem específica sobre a Documentação. Para a autora, o desenvolvimento espanhol do que se convencionou chamar como Ciencias de la Información é atrelado a uma grande área que abarca disciplinas como a Documentação e outras dedicadas à Comunicação, como o Jornalismo e a Publicidade. Contudo, essa ampliação conceitual também encontrou resistência no que se convencionou como Ciência da Informação em outros países, por não reconhecerem a conexão direta dos estudos realizados em seu âmbito com o avanço proposto pela área da Documentação.

Tal divergência ocorre, segundo Tálamo e Smit (2007), pelo fato de que, no contexto anglo-saxão, e onde as ideias francófonas tiveram menor penetração, o marco inicial dado para a Ciência da Informação ocorreu nos anos 1950, no pós Segunda Guerra Mundial. Nesse sentido, a Ciência da Informação teria nascido em um ambiente claramente influenciado pela corrida tecnológica que se deu ao término do conflito mundial, devido ao começo da Guerra Fria entre as duas potências econômicas do período, Estados Unidos da América e a União Soviética - URSS. A informação, ou melhor, o controle, recuperação e acesso a ela, foi tida como elemento estratégico em operações de caráter desenvolvimentista, gerando uma série de estudos e pesquisas a partir desta característica. Conforme destacam as autoras, nesse contexto:

A aproximação cada vez maior da Documentação ao modelo de cientificidade moderna tem sua origem, provavelmente, na importância do conhecimento já produzido na geração de um conhecimento científico cada vez mais especializado e objetivo, com capacidade ampla de manipulação da realidade. A documentação especializada, desenvolvida em ambiente privado, apropria-se cada vez mais dos conteúdos sob uma única ótica, a da sua utilidade. $O$ avanço tecnológico, dependente cada vez mais do conhecimento científico, exige, de início, uma estratégia para enfrentar o acúmulo quantitativo de informações. Simplifica-se a documentação, transformando-a em técnica de tratamento da quantidade de documentos, um serviço descomprometido, alienado dos princípios propostos por Otlet. (TÁLAMO E SMIT, 2007, p. 46-47)

A esse respeito, é possível citar a explicação de Ortega (2009), com base em López Yepes, que diz que o conceito otletiano se pulverizou e se fragmentou devido, em grande parte, à polêmica existente entre Biblioteconomia e Documentação, principalmente no que se refere às delimitações dos campos de atuações profissionais, sem que isso implicasse o avanço das disciplinas. Ela explica também 
que a preponderância da abordagem anglo-saxônica, mais propriamente estadunidense, sobre as questões informativas é notória.

A corrente estadunidense, desenvolvida a partir da década de 1950 no pós Segunda Guerra Mundial teve pouca influência da Documentação, conforme sua concepção por Paul Otlet. Nesse país houve um deslocamento semântico do termo Documentação que aponta para dois sentidos: o da Documentação enquanto prática distinta da Biblioteconomia - ocorrida na década de 1950, auge do movimento dos Estados Unidos - e, posteriormente, como área sinônima de Information Retrieval ou Information Storage Retrieval (ORTEGA, 2009). Embora sem uma tradução exata para o português, a expressão Information Retrieval contempla os "estudos e atividades de armazenamento e recuperação da informação por meio de computadores, e se configura como uma das principais origens da Ciência da Informação nos Estados Unidos nos anos 1960" (ORTEGA, 2009, p. 15). Elementos dessa abordagem são visualizados já no artigo de Vannevar Bush intitulado "As we may think", publicado em 1945.

Ortega (2009) também destaca a existência de traços de elementos da Documentação com base em Otlet nas correntes soviéticas que, todavia, tiveram forte ênfase no estudo das propriedades da informação científica e nas leis que regem a atividade científica e informativa, e não exatamente em seu conteúdo. Nesse sentido, os estudiosos soviéticos preferiram adotar outra denominação para essa disciplina específica que não Documentação, considerada extremamente genérica e polissêmica. Essa denominação alternativa foi Informatika.

No caso brasileiro, Ortega (2009) ressalta que os princípios documentários em geral e a obra de Paul Otlet são mais conhecidos devido à ampla aplicação da CDU pelas bibliotecas, e por compor o conteúdo de vários cursos de graduação em Biblioteconomia existentes no país. Segundo a autora, a história da Documentação no Brasil é marcada por três períodos: o primeiro no início do século $X X$, devido ao projeto do International Institute of Bibliography; o segundo na década de 1940, com o movimento criado no país, que culminou com o surgimento do Instituto Brasileiro de Bibliografia e Documentação em 1954; e o terceiro marcado pela introdução da corrente norte-americana, assinalada pelo uso da expressão Ciência da Informação. Mais tarde, na década de 1980, a criação do Grupo TEMMA $^{2}$ na Escola de

\footnotetext{
${ }^{2}$ Segundo informação constante na página do diretório de grupos de pesquisa no Brasil do CNPq, o Grupo TEMMA atua na construção de conhecimentos relacionados à organização da informação.
} 
Comunicações e Artes da Universidade de São Paulo também trouxe novas contribuições, embora não periódicas, para a Ciência da Informação, devido à introdução de discussões fortemente centradas nas questões da Linguística Documentária e Análise Documentária.

\subsection{Documentação e Ciência da Informação}

Ao traçar um panorama sobre o uso da denominação Documentação, Ortega (2009) conclui que nos Estados Unidos houve forte ênfase às questões do processamento mecânico da informação. Comparativamente, as abordagens soviéticas e de outros países da Europa tendem a ser mais abrangentes e mais baseadas em princípios documentários de base otletiana. Já no Brasil, apesar da baixa representatividade e clareza absoluta em torno do que é Ciência da Informação, é perceptível a predominância da corrente estadunidense, particularmente visível nos cursos existentes de formação.

Em razão dessa preponderância e das suas consequências, não só no Brasil, há uma dispersão profissional que muito pouco tem colaborado para o avanço da área de $\mathrm{Cl}$, considerada por Ortega e outros autores, tais quais Lara (2012) e Smit (2008), como tributária da Documentação. Por isso, a própria falta de identidade da $\mathrm{Cl}$ enquanto disciplina, o que só reitera a necessidade da reintegração com os pressupostos da Documentação de base otletiana e da melhor delimitação disciplinar entre elas.

Muitos autores atribuem o surgimento da $\mathrm{Cl}$ à explosão do papel atribuído à informação no ambiente pós Segunda Guerra Mundial. Tálamo e Smit (2007) destacam a esse respeito que, em virtude de tal entendimento, muitos também são

\footnotetext{
Inicialmente, o grupo concentrou seus esforços nas reflexões teóricas e práticas da Análise Documentária, enfatizando os procedimentos que subjazem à atividade da "representação do conteúdo". A elaboração de diferentes pesquisas permitiu diferenciar claramente, na temática do grupo, três eixos de ação: a) o processo da análise documentária, principalmente a indexação enquanto procedimento de representação da informação contida em documentos, e a elaboração de resumos; b) a função comunicacional dos produtos gerados pela análise documentária, resumos e índices; c) a construção de linguagens de organização e transferência de informação. O Grupo TEMMA é reconhecido nacionalmente como o único grupo formalmente voltado para as pesquisas relacionadas à organização da informação: seus pesquisadores orientam na pós-graduação e atuam na graduação em temáticas relacionadas aos objetivos do Grupo. Sua produção bibliográfica constitui bibliografia básica para os cursos de graduação e pós-graduação brasileiros e espanhóis. Segundo dados da mesma página, datados de março de 2012, as líderes do grupo são a Profa. Dra. Marilda Lopes Ginez de Lara e a Profa. Dra. Johanna Smit, da ECA-USP. Disponível em: $<$ http://dgp.cnpq.br/buscaoperacional/detalhegrupo.jsp?grupo=0067607UVP2I76>. Acesso em: 16 jun. 2013.
} 
os autores que vinculam o nascimento da $\mathrm{Cl}$ à figura de Vannevar Bush, cientista do Massachusetts Institute of Technology - MIT - que escreveu o já citado artigo intitulado As we may think, publicado em 1945. Tal artigo é tido como uma das primeiras manifestações em prol de uma área específica para o estudo da informação, mas com forte ênfase nas questões de automação da informação. $\mathrm{Na}$ abordagem proposta por Bush, segundo Saracevic (1997), o desenvolvimento da indústria da informação teve papel central no que denominou como explosão informacional e que acarretou, em governos e empresas privadas, a necessidade de controlar a informação. Desse modo, a perspectiva adotada nos Estados Unidos foi bastante específica em relação ao que se desenvolvia na Europa e marca fortemente, até os dias atuais, o que se entende por Ciência da Informação.

Segundo Saraceviv (1996), a Cl é uma ciência mutante que, enquanto campo, engloba tanto a pesquisa científica, quanto a prática profissional, bem como os problemas e métodos que escolheu ao longo do tempo. O autor ainda indica três características específicas da Ciência da Informação: possui natureza interdisciplinar; está ligada diretamente à tecnologia da informação; e, por último, é "uma participante ativa e deliberada da evolução da sociedade da informação" (SARACEVIC, 1996, p. 42). Nesse sentido, Tálamo e Smit (2007) destacam que esse caráter de análise teórica, aliado a propostas específicas de intervenção na realidade, constituem a disciplinaridade da $\mathrm{Cl}$, localizando-a, deste modo, no âmbito das ciências sociais aplicadas. O mesmo autor também destaca que, apesar de problemas ligados à informação serem tão antigos, o fato da dimensão informacional da realidade ter ganhado tal proporção fez com que a percepção em torno de tais problemas se modificasse com o passar dos anos. Esse seria um dos principais motivos para o surgimento da Cl, que teria, segundo Saracevic (1997), conhecido um desenvolvimento histórico de tal modo a acompanhar as alterações das percepções em torno do papel da informação. O autor defende ainda que os conceitos comuns, ou básicos, da $\mathrm{Cl}$ teriam conhecido uma uniformização global com o decorrer dos anos, sendo possível falar que "o despertar da $\mathrm{Cl}$ foi o mesmo em todo o mundo" (SARACEVIC, 1997, p. 43).

Contudo, Tálamo e Smit (2007) discordam, assim como Ortega (2009), de que a $\mathrm{Cl}$ conheça tal uniformidade de conceitos. Para as autoras, a $\mathrm{Cl}$ vivencia hoje uma crise em torno da sua especificidade enquanto área de conhecimento. $O$ fato da interdisciplinaridade ser entendida como uma característica definidora da $\mathrm{Cl}$ 
demonstra antes a manutenção de uma circularidade acadêmica que não promove o seu avanço enquanto disciplina. Ortega (2009), por sua vez, esclarece que o presente momento de crise identitária da $\mathrm{Cl}$ se deve em grande parte pela ausência da recuperação das origens históricas da mesma no movimento da Documentação. Tal perspectiva é compartilhada por Buckland (1991), que é tido como autor contemporâneo responsável por recuperar as contribuições dos fundadores da Documentação, Paul Otlet e Henri La Fontaine, e de sua principal discípula, Suzanne Briet, frente às discussões contemporâneas sobre a $\mathrm{Cl}$.

Para Ortega, adotar a Documentação como corrente principal para fundamentar a $\mathrm{Cl}$, torna possível "superar as abordagens restritivas atribuídas à Biblioteconomia e os contínuos e circulares embates sobre o objeto da Ciência da Informação" (2009, p. 30). Para a autora, ao contrário da Cl, a Documentação conquistou sólidas contribuições na literatura e na prática, apresentando foco e densidade ao longo do tempo. Por esses motivos, segundo ela, a incorporação do corpus teórico da Documentação como base da $\mathrm{Cl}$ ainda permite ir além dos discursos que reiteram a fragilidade e a ausência de consenso da $\mathrm{Cl}$, e avançar na delimitação identitária do campo.

Em resumo, a Documentação em suas diferentes fases também se dedicou a compreender e ampliar sua definição de documento e, consequentemente, também de informação. Muito embora tenha nascido sob a perspectiva universalista de Otlet, e com pouca atenção à questão das diversas variantes que influenciam a análise dos documentos e de produção da informação, as novas correntes que surgiram posteriormente vieram justamente propor novas reflexões em torno desse aspecto. Reconhece-se, portanto, a necessidade da apresentação em detalhe das abordagens da Documentação sobre essa noção de documento, as quais preveem que quaisquer elementos existentes na realidade social são passíveis de serem considerados como informativos e, logo, documentos. Considera-se que a $\mathrm{Cl}$ pode se valer dos pressupostos da Documentação para avançar em novas propostas e olhares sobre os diferentes processos pelos quais a informação se cria, estrutura e difunde, em termos sociais, culturais, tecnológicos e individuais - o que constitui o seu foco enquanto disciplina.

No que tange à Museologia, conforme será apresentado a seguir, incorporar a noção de documento no corpus da Documentação, e seus desdobramentos na própria $\mathrm{Cl}$, é um dos caminhos para aprofundar o entendimento próprio da noção de 
objeto como documento e estruturar teoricamente novas formas de organização e tratamento de acervos de museu - dois aspectos que são lacunares em seu corpus teórico.

\subsection{A noção de documento em foco}

O termo documento é um conceito central para a Documentação. Como foi possível entrever na breve exposição acerca do movimento surgido no final do século $\mathrm{XIX}$ e que se desenvolveu na primeira metade do século $X X$, assim como 0 próprio termo Documentação, o termo documento possui diferentes concepções. É possível afirmar que as variações de significado do termo, muito mais do que uma possível ausência de sistematização conceitual, são representativas de seus diferentes contextos de uso, conforme destaca Lund (2009).

O foco sobre a discussão da Documentação em torno do termo é válido por ser considerado central também para a reflexão sobre a noção de documento adotada pela própria Ciência da Informação (LARA; ORTEGA, 2011). Nesse sentido, Lara e Ortega (2011) iniciam a revisão do termo documento, estipulando como pressuposto inicial que aquilo que o define é a sua capacidade informativa. Portanto, não há nenhum documento possível de ser considerado como tal, como se isso fosse uma característica imanente. A sua construção enquanto tal demanda que seja apreendido como informativo.

De acordo com Lara e Ortega (2009), e Tálamo e Smit (2007), no Traité Otlet especifica que o documento não é só o livro em seu formato convencional, ao apresentar uma noção de documento bastante abrangente: livros, discos, folhetos, cartas, revistas, objetos da natureza, objetos criados com finalidade estética ou artística. Bibliotecas, arquivos e museus são entendidos como instituições dedicadas à Documentação. O documento, apesar da existência da preponderância do registro textual, é definido não mais por causa de sua materialidade, mas por sua função de expressar o conhecimento humano (SMIT, 2008). De acordo com essa perspectiva, Smit (2008) ressalta que o documento pode ser usado como referência para estudo, ou argumento para autoridade. É o que a autora denomina de abordagem funcionalista do documento.

Já no caso de Briet, Buckland (1997) chama a atenção para o fato de que, apesar da autora não deixar claro quais seriam as regras, por exemplo, para que um 
objeto torne-se um documento, é possível inferir algumas características do processo, entre elas: materialidade; intencionalidade, há intenção de que o objeto seja tratado como documento; processamento, os objetos têm que ser transformados em documentos; e posicionamento fenomenológico, o objeto deve ser percebido como documento. Essa versão clássica da noção de documento, que se estabelece como uma abordagem ampla sobre os tipos de registro que podem ser criados pelo ser humano, e que podem vir a se tornar documentos, ganhou desdobramentos em solo francês. Entre vários autores franceses citados por Lara e Ortega (2011), é possível destacar a contribuição de Meyriat, que define documento como um objeto que "dá suporte à informação, que serve para comunicar e é durável" (LARA; ORTEGA, 2011, p. 21).

De acordo com as autoras, uma preocupação central de Meyriat é o modo pelo qual um objeto se torna documento. Para ele, para entender algo como documento, seria preciso antes compreender a mensagem que o mesmo tem a função de transmitir. Conforme destacam Lara e Ortega (2011), entra em cena, aqui, a noção de atribuição, já existente na obra de Briet, como destacado por Buckland (1997), mas problematizada no contexto da relação entre emissor e sujeito interessado em se informar. E é justamente no momento da busca de um documento que o próprio se constitui enquanto tal - totalmente atrelado a uma necessidade ou desejo de informação, seja ela de ordem pragmática ou estética. Nesse sentido, conforme indicam as autoras, Meyriat estabelece as noções de documento por intenção, aqueles criados conscientemente para informar, e documentos por atribuição, aqueles que não foram criados com essa intenção, mas que podem ser transformados em informativos. Conforme resumo das contribuições do autor feito por Lara e Ortega (2011, p. 21-22), é possível estabelecer a compreensão de que um documento nem sempre é usado como tal e que, por outro lado, um documento por atribuição também pode deixar de sê-lo a depender das mudanças nas necessidades ou desejos de informação.

Ao analisar o uso da noção de documento em contexto espanhol, as autoras ressaltam que a influência otletiana também é preponderante. Desantes Guanter é um dos autores citados por Lara e Ortega (2011) como um dos principais autores dessa corrente espanhola. Para ele, a noção de documento e informação caminham juntas. Desse modo, na perspectiva do autor, a documentação só faz sentido se for informada, tornando-se mais potente e consolidada. Em outras palavras, a 
documentação que não é considerada como informação se constitui como uma contradição conceitual (LARA; ORTEGA, 2011). Para outros autores espanhóis, como Sagredo Férnandez e Izquierdo Arroyo, o documento só pode ser considerado como tal se for utilizado como documento, reforçando uma característica já percebida entre os seguidores das ideias de Otlet em solo francês. López Yepez destaca, nesse sentido, o papel do documentalista na transformação de algo em objeto, pois é ele que modifica a mensagem original em mensagem documentária, e a torna fonte seletiva de informação.

Segundo Lara e Ortega (2011), no contexto anglo-saxão, a noção de documento ganha outras abordagens. Buckland, um dos autores representantes desse contexto, retoma a noção clássica de documento proposta por Otlet e pelos primeiros documentalistas, com destaque para a:

necessidade de definição de documento e documentação que inclua objetos
naturais, artefatos, objetos apontando pistas de atividades humanas,
objetos tais como modelos designados para representar ideias, e obras de
artes, assim como textos. [Buckland] Comenta que o termo documento (ou
unidade documentária) foi usado no sentido especializado como um termo
genérico para denotar objetos físicos informativos. (LARA; ORTEGA, 2009,
p. 131).

Buckland (1997) ainda pondera que o conceito de documento, de acordo com as discussões realizadas por documentalistas e bibliógrafos da Documentação, pode ser dividido em três categorias: artefatos que foram feitos para constituir discurso, como livros; artefatos que não foram feitos com esta intenção, como barcos; e objetos que não são artefatos, como antílopes. Ele também define que os registros de eventos, seguindo essa perspectiva, também podem ser considerados como objetos informativos, e não o evento em si.

Lara e Ortega (2009) destacam a contribuição de Frohmann, que ressalta a importância do movimento documentalista do final do século XIX e início do XX. Para esse autor, é a informatividade que define um documento. Para um objeto ser informativo, será necessário verificar sua materialidade, seus lugares institucionais, os modos pelos quais é socialmente disciplinado e sua contingência histórica. Frohmann relaciona fortemente as noções de informação e documento, caracterizando-o como "materialidade da informação" (LARA; ORTEGA, 2009, p. 132). 
Frohmann (2008) também se baseia em Foucault para discorrer sobre a materialização da informação, deste modo, introduz a crítica de Foucault à noção de documento, para quem o mesmo se constrói no âmago das práticas e relações sociais, no âmbito das quais se realizam disputas de poder e influência. Segundo Frohmann, para Foucault o estudo da documentação - a materialização da informação como um todo - permite a compreensão dos processos de escrita disciplinar que se dá através das instituições e confere à informação peso, inércia e estabilidade, podendo marcar profundamente a vida social. Em outras palavras, o que é considerado como "documento" e "informativo" será influenciado em grande parte pelas instituições disciplinares, como os órgãos de justiça, as escolhas e os hospitais.

Na opinião de Lara e Ortega (2011) as teorias semânticas também são importantes para a discussão do termo, pois ressaltam outros aspectos dos processos de produção e uso dos documentos, da mesma forma que o jogo interpretativo como parte fundamental da comunicação.

Ao adotar os pressupostos da Semiótica no processo de comunicação, o documento, particularmente se entendido na perspectiva da Documentação e do documento secundário de Briet, é produto de uma relação que envolve emissor, interlocutor e contexto. Outro aspecto que Lara e Ortega (2011) salientam é que, na abordagem semiótica, a atividade de representação dos documentos, que por si só são construções, é marcada por escolhas e elementos ideológicos. Sendo assim, ao categorizarem os documentos, as representações documentárias priorizam determinados aspectos dos documentos em detrimento de outros, o que tem implicações diretas em sua significação.

Segundo as autoras, entender o documento como signo implica correlacionar uma forma significante e um significado que é independente do objeto ao qual pode ser referido. Isto se dá porque a apreensão do signo é sempre incompleta, parte do processo de significação não se refere só a si mesmo, é dependente de contextos culturais onde se insere o intérprete. Com sua independência do objeto físico, o signo sempre é dinâmico, representando apenas temporária e parcialmente esse mesmo objeto. São essas as características que permitem confirmar que o documento, entendido como tal, é uma construção, uma possibilidade de interpretação do real dentro de determinado contexto. Neste ponto, as autoras introduzem a ideia de signo documentário, que possui determinadas restrições em 
relação ao signo de um modo geral, porque seu "significado é produto das relações lógico-semânticas que compõem a linguagem documentária, sua fonte de referência" (LARA; ORTEGA, 2011, p. 34). É produto também das referências que caracterizam as condições de sua produção, como autor, título, editor, etc. Essas condições também compõem índices e auxiliam nas representações do documento nas operações de busca pela informação, tanto quanto as linguagens documentárias ${ }^{3}$.

Por último, as autoras ressaltam que, apesar das características do documento-signo documentário colocarem em primeiro plano sua significação, não é possível, do ponto de vista pragmático das instituições, que esta significação seja referenciada apenas pelas subjetividades dos interessados que buscam pelos documentos, tendo em vista que são aleatórias. Nesse sentido, é possível interpretar o signo documentário como uma oferta de sentido - mensagem -, tal como sugere Luhmann (1987, apud CAPURRO, 2003), que é viabilizada pelos sistemas documentários, através de referenciais como a linguagem documentária e as regras de descrição formal. Mas, conforme ressaltam Lara e Ortega (2011) essas ofertas de sentidos são a representação de apenas um ponto de vista, e não o único possível.

Para se garantir que a comunicação entre instituições e públicos aconteça de modo a tornar a busca pela informação mais precisa para ambos os lados, Lara e Ortega (2011) destacam que é preciso que a instituição estruture linguagens documentárias com base: na observação do que interessa, em termos conceituais, aos sujeitos de uma comunidade discursiva e que provavelmente terá influência no seu entendimento do que é documento ou não; e na confirmação, no que se refere às regras de descrição formal do documento, de que se esgotaram todos os aspectos que permitem uma representação consensual do mesmo. Em outras palavras, a instituição deve privilegiar a descrição de atributos ou propriedades dos documentos, de acordo com o que observa simultaneamente a produção e recepção da informação.

O documento pode ser entendido também como algo que é socialmente e culturalmente construído, sendo seu status de documento algo transitório. Torna-se

\footnotetext{
${ }^{3}$ Conforme explica Lund (2009), existem três tipos de signo presentes na teoria dos signos de Charles S. Pierce: o primeiro, os signos-ícone, que não possuem nenhuma relação dinâmica com o objeto que representam e cujas qualidades simplesmente se assemelham àquele objeto, provocando sensações análogas; em segundo, há as indicações ou índices, que mostram algo sobre alguma coisa devido ao fato de estarem conectados fisicamente; e, por último, os signos-símbolo ou signos gerais, que se tornaram associados com seus significados devido ao seu uso.
} 
possível, a partir dos pressupostos apresentados da Documentação até o momento, entender que, de fato, qualquer elemento existente na realidade pode ser algo construído como um documento, incluindo os objetos de museus. Porém, essa aproximação demanda que sejam detalhados os desdobramentos dessa afirmação, que serão abordados no próximo tópico.

A partir desse panorama histórico apresentado pelas autoras, é possível considerar as contribuições de Otlet, dos demais autores por ele influenciados e também de teorias de outras áreas como a Semiótica, fundamentais para a compreensão da noção de documento. Para o âmbito específico da Ciência da Informação, o documento se constitui enquanto tal, a partir do uso informacional que dele se faz, tendo os profissionais da informação e suas práticas um papel fundamental no tratamento de objetos e sua posterior apropriação pelas comunidades potencialmente usuárias da informação.

\subsection{A noção de objeto para a Museologia}

Objeto é um termo presente em grande parte da bibliografia da área da Museologia, particularmente a que se refere aos conceitos chave da área (MENSCH, 1992; CERAVOLO, 2009; DESVALLÉS; MAIRESSE, 2010). Conforme os levantamentos feitos por Mensch (1992) e Ceravolo (2009) sobre a produção bibliográfica do Comitê Internacional para a Museologia - ICOFOM - do Conselho Internacional de Museus - ICOM -, que desde sua criação em 1977 se constitui como um dos principais fóruns de discussão teórica da área, é possível verificar proposições diversas em torno do termo e seu significado durante toda década de 1980 e início da de 1990.

Mensch (1992) destaca que tal discussão é composta preponderantemente por autores europeus, em que há o protagonismo de autores como Zybnek Z. Stránský e Klaus Schreiner, compreendendo que apenas os artefatos, enquanto elementos produzidos pelo engenho humano, deveriam ser considerados como objetos, devendo o museu se preocupar unicamente com a preservação dessa forma de memória humana. Outros autores, como Ivo Mavoeric e o próprio Peter Van Mensch, também participantes das discussões promovidas pelo ICOFOM, já são partidários de noções mais amplas de objeto e museu, em que qualquer elemento existente da realidade concreta do ser humano poderia ser considerado 
como objeto, sendo o museu apenas um dos espaços destinados à sua preservação.

Para Mensch (1992), esse entendimento abrangente do objeto museológico corresponde a uma abordagem mais ampla da própria Museologia, na qual o museu seria apenas uma das possibilidades onde a musealização poderia ocorrer e os objetos de museu seriam apenas parte do que poderia ser considerado como patrimônio musealizado. Segundo o autor, a musealização poderia ocorrer em quaisquer instituições dedicadas à preservação da memória, como bibliotecas e arquivos. O objeto museológico, esteja no museu ou não, se constituiria em uma fonte ilimitada de informação e que demanda uma abordagem multidisciplinar para sua interpretação. Sobre Mensch (1994) ainda é válido ressaltar que ele fez parte de uma linha de autores que defenderam a autonomia disciplinar da Museologia como ciência, embora reconhecendo a ausência de delimitação do objeto de estudo. $O$ autor destaca a diversidade de abordagens sobre o que seria Museologia, o que para ele impediu a consolidação de um pensamento único sobre seu significado.

Em 1986, o ICOFOM - Comitê Internacional para a Museologia do Conselho Internacional de Museus - procurou fazer, por meio de um de seus eventos, uma discussão sistemática em torno do significado da palavra Museologia, procurando identificar a existência de um corpo teórico e prático válido para todo o mundo. Segundo Mensch (1994), os participantes do evento concordaram que, a partir desse exercício de elaboração a respeito do que seria a Museologia, no nível mais alto de abstração, foi possível inferir a existência de uma única Museologia, ou um objeto de estudo específico. Mas, ao ser confrontada com a realidade, essa Museologia deixava de ser uma para ser marcada pelas profundas diferenças entre as abordagens, a depender dos contextos de origem de cada uma. Desse modo, a proposta do ICOFOM de propor a discussão sobre o assunto só reforçou a profunda multiplicidade de olhares, fragmentários, sobre a Museologia, e não chegou a consolidar um objeto de estudo da área. Tal interpretação sobre o encaminhamento dado às discussões ocorridas na década de 1980 no âmbito do ICOFOM também está presente em Ceravolo (2004).

Para Mensch, tais diferenças entre os olhares seriam decorrentes das condições socioculturais e econômicas de desenvolvimento da Museologia em cada um dos contextos de origem representados naquela reunião do ICOFOM. Ao ampliar seu escopo de análise, Mensch (1994) explica que a partir da literatura existente 
sobre o tema à época, foi possível para ele identificar a existência de seis tendências sobre a Museologia, a saber: a Museologia como ciência dos museus; como estudo de atividades relativas ao museu e à preservação da herança cultural; como estudo de objetos de museu; área dedicada ao estudo da musealidade; até chegar à concepção da Museologia como estudo da relação específica do homem com a realidade. Neste último caso, a relação específica do homem com a realidade se expressa na seleção e preservação de objetos em uma nova realidade, que podem ser utilizados conforme a necessidade. Nessa abordagem, o museu convencionado pelo modelo estabelecido desde o século XIX é apenas uma das possibilidades de manifestação dessa relação, pois a Museologia pode englobar outras formas de museu bastante distintas. A esse respeito, Mensch (1994) ressalta que essa abordagem poderia ser considerada como um consenso final possível para a discussão.

O autor destaca que essa tendência foi seguida particularmente pela autora brasileira Waldisa Russio Guarnieri, que desenvolveu o conceito de fato museal como a relação processual do homem com o objeto em um cenário, particularmente, aquele institucionalizado pelo museu. Nesse sentido, a Museologia seria a ciência que estudaria o fato museal, sendo o objeto museológico uma fonte ilimitada de informação. Ou, em outras palavras, para Guarnieri (1990), qualquer testemunho do homem e do seu meio físico ou natural ou transfromado poderia ser musealizado, desde que tivesse significação - estabelecida pelo próprio fato museológico em si.A esse respeito, Cândido (2008) também ressalta que esse conceito, conforme definido por Waldisa Russio, pode ser considerado uma das principais contribuições brasileiras para a discussão epistemológica sobre a Museologia, e que foi justamente pela forte atuação dessa autora que a tendência em questão foi a que mais se difundiu no Brasil.

Com estrutura semelhante ao texto de Mensch (1994), Cândido (2008) procura sistematizar as contribuições teóricas sobre a Museologia no Brasil e realizar uma análise sobre elas. Para essa autora, o Brasil, por ser um país diverso social e culturalmente, possui potencial para o desenvolvimento de modelos de aplicação da Museologia distintos. A diversidade de olhares, no entanto, é entendida por ela como resultantes da adaptação, mas também da criação de procedimentos metodológicos adequados aos contextos de implantação das ações museológica. A teoria da Museologia, nesse sentido, deve ser confrontada com a realidade, e a 
partir deste enfrentamento é que se definem os modelos a serem seguidos. Deste modo, diferentemente do que indica o texto de Mensch (1994), a existência de várias abordagens não é considerada inviabilizadora de um objeto de estudo da disciplina, e permite que a Museologia renove suas práticas de modo adequado aos contextos de aplicação. A revisão bibliográfica feita por Cândido (2008) demonstra ainda que as variações dos modelos partem, na origem, de um conjunto de pressupostos teóricos comuns, ou seja, a abordagem da Museologia como o estudo do fato museal. Para um terceiro grupo de autores, como Cury (2005), a discussão sobre a cientificidade da Museologia ainda encontra-se em consolidação.

Atualmente, no âmbito internacional, há autores como Deloche (apud Desvallées; Mairesse, 2009), que já definem a Museologia como uma disciplina ontológica, de natureza filosófica, que se dedica a estudar todo o campo museal. Para esse autor, ela se preocupa com um tipo específico de relação do homem com a realidade, a qual é expressa através da documentação daquilo que é real e pode ser apreendido através de contato sensorial direto. Nessa compreensão, que deixa de discutir se a Museologia é uma ciência ou não, são consideradas todas as formas e tipos de museu, dos mais tradicionais aos cibermuseus e, consequentemente, de objetos, aquilo que é real, que deles fazem parte.

Um ponto a ser destacado na discussão sobre Museologia é que ela se distingue da área de museus, embora dela possa fazer parte, e vice-versa. Faz-se a separação entre área de museus e Museologia, pois se entende a Museologia como uma disciplina que não é afeita somente ao universo dos museus, mas tem como propósito de estudo os processos e relações entre os seres humanos e sua memória materializada, em um determinado espaço. Por último, vale ressaltar que parte-se do pressuposto que o ponto de encontro entre a área de museus e a Museologia se dê, particularmente, na Museografia. Desvallées e Mairesse (2009) definem Museografia como:

o aspecto prático ou aplicado da museologia, ou seja as técnicas que foram desenvolvidas para dar conta das operações museais, em particular no que se refere ao planejamento e ao alcance às premissas de um museu, conservação, restauração, segurança e exibição. Em contraste com a Museologia, a palavra Museografia já é utilizada há muito tempo para identificar as atividades práticas associadas aos museus. (DESVALLÉES; MAIRESSE, 2009, p. 52. Tradução da autora) 
A esse respeito, Loureiro (2008) diverge da tradicional e, para ele, falsa dicotomia entre Museografia, dimensão técnica e operacional da prática dos museus, e a Museologia, teoria, por entender que ambas compõem um único ente disciplinar responsável por pensar e propor estratégias de musealização. Segundo esse autor, a museografia é um conjunto de ações que envolve teorias e práticas destinadas aos fins estabelecidos pelos espaços musealizados, e que é totalmente alicerçado na disciplina Museologia. E esse espaço não necessariamente se refere apenas aos museus. Por outro lado, a área de museus engloba uma série de conhecimentos diversos, que podem ter influência direta das disciplinas de base dos museus - Arqueologia, Artes, Biologia, Física, etc. Nesse sentido, é possível ter a opinião de autores que, apesar de não serem museólogos ou oriundos da Museologia, escrevem sobre museus e suas funções.

Como se pode observar, a discussão em torno do objeto de estudo da Museologia, do lugar que a noção de objeto, de museu, ocupa nesse âmbito e da sua cientificidade não é recente e tão pouco consensual (CERAVOLO, 2004). primeiro ponto a ser destacado entre os autores que se dedicaram ou se dedicam ao tema é o fato de buscarem, muitas vezes a partir de pontos de vista divergentes, a estruturação de tendências epistemológicas e uma melhor relação entre a consolidação de uma teoria museológica e a prática.

Apesar das distinções entre as abordagens, algo é comum a todas: a ressalva à função documental que o objeto passa a desempenhar quando inserido no contexto do museu. Independentemente de serem artefatos em um sentido restrito, ou serem elementos imateriais, ou do meio ambiente físico, os objetos adquirem novos significados ao serem adquiridos e trabalhados pelo museu. Portanto, vale ressaltar a importância de se compreender preliminarmente o que implica a transformação de um objeto comum em objeto de museu e, por consequência, em um documento.

Um pressuposto inicial para a discussão é a compreensão de que o objeto pode ser entendido como qualquer elemento que se materializa, ainda que de forma temporária ${ }^{4}$ na realidade social, que possui sentido para os sujeitos que com ele se relacionam. Nessa relação cotidiana, muitas vezes quase inconsciente e pautada

\footnotetext{
${ }^{4}$ Como no caso dos saberes e fazeres, como danças, músicas, conhecimentos culinários e medicinais, e mesmo os ofícios que apesar de intangíveis se materializam, momentânea ou permanentemente, em coisas físicas para serem operacionalizados, sendo dependentes da ação de sujeitos (FONSECA, 2003).
} 
pela funcionalidade, os objetos "são não apenas produtos, mas vetores de relações sociais" (MENESES, 1994, p. 12). Trata-se, na perspectiva do autor, de uma superação da dicotomia entre cultura material e não material, ou de fenômenos sociais materiais e não materiais. Castro (2009) ainda ressalta, a esse respeito, que os objetos possuem a característica da permanência, devido ao seu status diferenciado das coisas. A autora pondera que "o objeto seria como uma configuração mutante, episódica, ligada a estruturas sociais e sistemas mentais, o que lhes vêm confirmar a permanência" (CASTRO, 2009, p. 69). Para viabilizar sua permanência, a autora ressalta que o objeto é reconduzido para se transformar em relato, sendo acrescido da instância de documento de uma história. E é com esta categoria de elementos da realidade, cujo status ontológico foi modificado devido à sua mobilização para ser um objeto, que operam os museus. Compreende-se, dessa forma, que quando selecionados para integrar a coleção de uma instituição - e assim transformados em museológicos - os objetos se estabelecem não somente como evidências de si mesmos, mas também de redes de relações socioculturais, de códigos e contextos históricos dos quais são provenientes.

Em uma linha semelhante a Meneses (1994), Mensch (1992) salienta que o objeto pode ser entendido como a menor parte da cultura material que possui em si mesmo, uma identidade reconhecível e reconhecida. Novamente se identificam as características da natureza ontológica do objeto: sua presença física, ainda que temporária, deve ser conhecida dentro de um determinado contexto e esta precisa ser reconhecida como tal pelos sujeitos que com ele se relacionam. $\mathrm{O}$ autor, citando James Deetz, define cultura material como a parte do meio ambiente físico modificada através do comportamento humano culturalmente determinado, e que é resultante dos pensamentos humanos. A interpretação de cultura material proposta por Deetz não se limita, na visão de Mensch, somente aos artefatos tangíveis e móveis, mas inclui todos os tipos de artefatos, desde os mais simples, como um alfinete, até os mais complexos, como os veículos interplanetários. Também engloba paisagens naturais e animais, dando o exemplo de campos de arado e criações de cavalo como parte da cultura material, pois as criações científicas de animais são culturalmente condicionadas. O 'material', nessa abordagem, é apenas parte do foco de análise, pois o que importa é o universo da cultura onde se inserem os elementos. 
Transpondo a discussão para o contexto do museu, Mensch (1992) ressalta que, a partir dessa compreensão e citando Ivo Mavoeric, qualquer elemento existente na realidade social com o qual o ser humano estabelece uma relação de sentido pode ser passível de ser transformado em objeto museológico. Sendo assim, toda e qualquer coisa, artefato ou paisagem, material ou imaterial, poderia ser selecionada para passar pelo processo de musealização, processo de seleção de objetos e seu processamento no contexto do museu, e se transformar em fonte de informação.

Para Meneses (1994), o papel do museu é justamente o de permitir que outros olhares sejam construídos sobre os elementos do cotidiano, de modo a explorar os fenômenos com os quais os artefatos se relacionam para que sejam interpretados de maneira mais ampla. Para ele, "no museu nos defrontamos com objetos enquanto objetos, em suas múltiplas significações e funções, ao contrário, por exemplo, do que ocorre num supermercado" (MENESES, 1994, p. 12). Consequentemente, ser um objeto de museu implica que um objeto adquira um novo significado e um novo status, diferente de sua vida como objeto do cotidiano, mas que a ela faz referência direta.

De forma a sintetizar todas as contribuições, é possível compreender que o objeto pode ser qualquer elemento materializado existente na realidade social e que possui um determinado significado para os seres humanos que com ele se relacionam. Os objetos integram, portanto, o universo da cultura. Podem ser desde esculturas, pinturas, equipamentos de trabalho até danças, músicas, vídeos, saberes e fazeres que, devido a uma primeira situação de significação, tornam-se objetos e deixam de ser coisas.

O objeto, ao ser transformado em museológico, passa por uma segunda operação de significação. Por causa de seu status como objeto - vetor de relações sociais e de formas de comunicação de valores, funções e símbolos culturais sendo justamente selecionado para compor um acervo de museu. Mas ao passar por esse processo, deixa de operar enquanto um objeto que é do cotidiano para ser mobilizado institucionalmente, enquanto uma referência de um determinado contexto social, histórico e cultural. O significado do objeto museológico é diferente, portanto, do objeto comum. Esse significado diferenciado agrega o significado primeiro do objeto, mas o expande por meio do trabalho do museu: o objeto passa a ser interpretado, então, como um documento. 
Mas, se por um lado é possível compreender o objeto museológico como uma fonte de informação, quais implicações essa constatação teria mediante a discussão da própria noção de documento? É esta reflexão que será abordada a seguir.

\subsubsection{O objeto de museu como documento}

Conforme visto anteriormente, a própria noção clássica de documento apresentada pela Documentação e seu desenvolvimento até os dias atuais pela Ciência da Informação demonstram que todo e qualquer objeto produzido pelo homem, ou mesmo pela natureza, pode ser uma coisa passível de se transformar em documento - o que é coerente com a noção apresentada de objeto. Desse modo, é possível compreender que ser um objeto e ser um documento são dois estados ontológicos possíveis de serem atribuídos a algo que existe na realidade, sendo que no caso dos objetos que foram musealizados, essas duas condições parecem se sobrepor.

Diante do exposto, é possível dizer que a abordagem semiótica do documento contribui especificamente para a compreensão do objeto de museu-documento, pelas razões já expostas anteriormente por Lara e Ortega $(2009,2011)$. O processo de qualificação - a musealização - de um objeto como de museu permite a sua construção como signo documentário, instituindo-lhe um caráter de referência informacional, em testemunho ou registro de eventos, ou fenômenos sócioculturais.

A musealização é o meio pelo qual se dá a construção de um objeto como sendo de museu e sua transformação em documento, algo que se torna informativo diante de uma perspectiva que envolve, ou assim deveria, uma política institucional. A musealização também inscreve o objeto na lógica contemporânea do museu, que não corresponde à lógica da sua produção, ou a de seu uso (MENESES, 1994; MENSCH, 1992). Ele transforma-se em indício de um contexto, fenômeno ou evento, que será reunido a outros objetos e com eles, a partir da contextualização produzida pelas práticas documentárias, conformará uma nova realidade - a do museu, marcada por seus esquemas classificatórios, formas e espaços de exibição.

Para Cury (2005), a musealização começa com a seleção do objeto, mas se estende a outras atividades posteriores de institucionalização. Desse modo, a autora entende a musealização como uma ação de natureza fundamentalmente conceitual, que se inicia com os critérios atribuídos pela instituição para realizar a seleção, mas 
que depois se operacionaliza por meio do trabalho cotidiano do museu, incluindo-se a documentação.

Aqui, da mesma maneira como ressaltado por autores como López Yepes, o papel dos profissionais é crucial na construção do documento. Torna-se, então, fundamental que o museu, ainda que não seja uma instituição exclusivamente dedicada à atividade documentária, mas que tem nela uma base fundamental (MENESES, 1994), realize um duplo movimento: institua uma política de formação de acervo que seja calcada na missão institucional e realize um processamento da informação sobre o acervo, tendo por base teórica as noções de objeto de museu e documento e, por base empírica, a sua própria missão e objetivos.

Sobre o primeiro movimento, como bem ressaltaram Meneses (1994) e também Bittencourt (2005), é possível dizer que um museu que não assume um papel ativo na formação de acervos fica refém de coleções constituídas de maneira reativa, baseadas em doações espontâneas de particulares. Meneses (1994) ressalta ainda que muitas dessas doações são representantes da autoimagem dos doadores, permitindo um uso praticamente nulo dos objetos como documentos, pois seu significado escapa ao objetivo maior do museu.

A postura reativa do museu também pode ser entendida, no dizer de Bittencourt (2005) citando Burcaw e Stránsky, como sinônimo de um simples aceite dos objetos por parte da instituição, sem nenhuma reflexão sobre o que adquire e sem o tratamento e produção de informações inerentes à musealização. Trata-se, portanto, de uma situação em que os objetos vão sendo acumulados pelas instituições, tornando-se apenas objetos em um museu e prejudicados em sua função enquanto documentos. Identificam-se, nesse caso, as consequências da desconsideração do que significa o ato de musealizar objetos e transformá-los em fontes com função documental, o que acarreta a museificação do objeto.

Em relação ao segundo movimento, parte-se do pressuposto que o processamento da informação de acervos e a produção de informações documentárias é uma etapa específica da musealização que possui impacto direto na construção do objeto como documento. A coleta, organização, tratamento, recuperação e difusão da informação sobre os objetos que compõem um acervo de museu devem ser, portanto, direcionadas também pela missão institucional, mas, sobretudo, devem buscar representar o objeto na sua complexidade. 
Nesse sentido, retomando a ressalva feita por Lara e Ortega (2011) sobre a questão da apropriação, o museu deve se preocupar não só com a descrição dos atributos físicos dos objetos; deve construir linguagens documentárias que se aproximem das comunidades de interesse e estruturar padrões de representação que deem conta das informações produzidas no contexto do museu. Dessa forma, o museu maximiza as possibilidades de diálogo do público com o acervo.

Isso não implica que o museu adote uma perspectiva comunicacional unilateral com seu público e, sim, que as formas de exibição e representação dos objetos encontrem os consensos possíveis, ampliando as possibilidades de leitura do mundo que se apresenta no espaço institucional. Os objetos museológicos devem ser trabalhados, enquanto documentos, como ofertas de sentido no âmbito dos horizontes do museu, sua missão, objetivos, tipologia, etc. Mas essas ofertas devem ser realizadas de uma forma dialógica e dinâmica com seus usuários, pois provavelmente não serão as únicas possíveis para o público.

Por último, cabe ressaltar que a consideração do objeto de museu como documento também leva ao entendimento de que sua atribuição, musealização, como tal é passível de revisão posterior, tendo em vista as características do signo documentário. Sem querer aprofundar esse tópico em específico, tendo em vista fugir do escopo do presente trabalho, em alguns casos, esta revisão pode ser encarada como parte de uma política de desvinculação de partes do acervo, que implica em reposicionamentos de peças em outras instituições, ou dentro da própria instituição. Trata-se de uma atualização das ofertas de sentido, que deve ser feita seguindo parâmetros éticos e legais existentes na área, e critérios fundamentados e amplamente difundidos.

Enfim, a partir do exposto, é possível dizer que as noções de objeto e documento são estruturantes, respectivamente, para a Museologia e a Ciência da Informação. A revisão de ambas, à luz de perspectivas históricas e epistemológicas, permite entrever as possibilidades de aproximação entre os diferentes quadros referenciais teóricos e também das tensões que essas aproximações podem trazer.

Portanto, compreender o objeto de museu enquanto documento, conforme a noção introduzida pelos primeiros documentalistas do movimento da Documentação e depois desenvolvida pela Ciência da Informação, implica em entendê-lo como algo construído, fruto de um exercício de seleção. Esse entendimento reforça particularmente o papel das práticas documentárias, ou da documentação entendida 
como um fazer, no processo de musealização e a importância da aproximação entre as áreas da Museologia e da Ciência da Informação nesse debate. É essa discussão em torno do que é documentação no contexto dos museus que será abordada na sequência. 


\section{O TERMO DOCUMENTAÇÃO NO CONTEXTO DOS MUSEUS: POLISSEMIA E PRESSUPOSTOS TEÓRICOS}

O foco deste terceiro capítulo é o termo documentação no contexto da literatura da Documentação, da Ciência da Informação e, majoritariamente, da Museologia. O objetivo é identificar como cada uma das áreas, no âmbito de seus contextos teóricos, usa o termo documentação e o relaciona ao universo dos museus. Subjacente a esse objetivo está novamente o interesse em compreender os traços e características que distinguem ou aproximam a aplicação do termo em cada uma dessas áreas citadas, a fim de compreender as diferentes nuances e quadraturas inerentes ao assunto.

Os procedimentos metodológicos utilizados para alcançar o objetivo envolveram levantamento bibliográfico, contextualização histórica e análise qualitativa do termo e suas variações, conforme os contextos correspondentes. $O$ levantamento ocorreu nas bases de dados do Sistema Integrado de Bibliotecas da USP - SIBi-USP -, do sistema de bibliotecas da UNESP, do SciELO-BR, da revista Museum/UNESCO e nos repositórios de dados dos sites do Conselho Internacional de Museus - ICOM - e do Comitê Internacional para Documentação - CIDOC. Um primeiro recorte para a busca foi a delimitação do idioma: a literatura possível de ser levantada foi produzida em português, inglês e espanhol. Vale ressaltar que há autores em diferentes línguas que dissertam sobre o assunto em pauta. Porém, embora identificados, não foram analisados textos em outros idiomas durante 0 período de levantamento bibliográfico.

As palavras-chave utilizadas para as operações de busca foram: documentação museológica, documentação museográfica, documentação de museus, sistema de documentação museológica; documentación museológica, documentación museográfica, documentación de museos, sistema de documentación; museum documentation, museum documentation system e collection management, gerando resultados diferentes em termos qualitativos e quantitativos. Após os resultados das buscas, foram priorizados os autores que: a) discutem especificamente a questão da documentação em museus, provenientes das áreas da Documentação, Ciência da Informação ou Museologia e b) possuem, 
em sua maioria, textos de referência, ou seja, que acabam tendo alto índice de citação em trabalhos uns dos outros.

A delimitação temporal da pesquisa usou, como datas limite, as décadas de 1950 - ano de fundação do CIDOC, considerado um marco fundamental na história da documentação em museus - e a década de 2000, de modo a contemplar aproximadamente o momento atual do trabalho. Assim, foi possível perfazer um arco no tempo considerado amplo o suficiente para levantar características históricas, linguísticas, conceituais - associadas ao uso do termo "documentação" no contexto dos museus. Um último recorte, decorrente diretamente dos dois anteriores, foi o contexto de origem dos autores: contexto internacional, marcado pela produção relacionada ao CIDOC; europeu, predominantemente Reino Unido e Espanha, estadunidense e brasileiro.

Cumpre ressaltar também que durante o levantamento bibliográfico observouse que os autores que atendiam aos critérios de seleção, em alguns casos, apresentaram outros aspectos importantes para a presente pesquisa, além da questão terminológica em torno da documentação. $O$ aspecto que será ressaltado aqui é o relacionado ao histórico da documentação no contexto dos museus construído por esses autores - o que foi fundamental para a primeira parte deste capítulo, por exemplo. Desse modo, é possível destacar a organização dos autores selecionados em dois grandes grupos: aqueles cuja produção é base para a contextualização histórica sobre documentação em museus, e aqueles - que podem incluir membros do primeiro grupo - que foram utilizados para fornecer maiores exemplos a respeito das apropriações do termo documentação em cada contexto tratando, assim, da questão terminológica.

A análise do termo documentação no contexto dos museus é apresentada em três subseções. A primeira buscou delinear apontamentos históricos sobre a atividade de documentação e sua relação com o universo dos museus, na forma de um panorama - e se vale das contribuições do primeiro grupo de autores mencionado. Tal panorama foi importante, pois se compreende que entender a historicidade da documentação é uma etapa que colabora na construção dos quadros teóricos, tendo como base os usos do termo na literatura levantada.

Vale salientar também que a contextualização auxilia a compreensão de características sociais, culturais e linguísticas de um determinado tempo e espaço que podem influenciar a apropriação do termo documentação pelos autores. Tal 
premissa baseia-se no entendimento da natureza da palavra, que é flexível no sentido de que seu significado é associado ao seu uso, podendo ser interpretado de diferentes formas a depender do contexto (BAKHTIN, 2004). Assim sendo, considera-se que um autor, ao propor uma definição sobre documentação, não a propõe sozinho, mas com toda a sua bagagem cultural, histórica, intelectual, etc., a partir das referências da sociedade onde vive.

Desse modo, o panorama apresenta, de forma introdutória, os modos de configuração e consolidação da atividade da documentação como um "fazer" de museu, inserindo-a na história no espectro maior dessa instituição. Tal história inicia-se nos gabinetes de curiosidades europeus - as raízes dos museus - dos séculos $\mathrm{XV}$ e $\mathrm{XVI}$, até a consolidação do modelo moderno de museu durante os séculos XVIII e XIX. O panorama acompanha também a expansão da instituição para a América, particularmente nos Estados Unidos e Brasil, focando as críticas ao modelo "europeu" de museu - e, consequentemente, ao modo de se fazer documentação em museus - no século XX. Muitas dessas críticas decorreram de movimentos sociais, artísticos e políticos ocorridos na região, e que tinham por objetivo maior o questionamento ou a luta contra uma ordem social e política estabelecida e suas instituições, marcada pela presença de ditaduras militares. Contudo, o mesmo não adentra, ainda, nas especificidades do significado do termo em cada contexto, o que é alvo da subseção seguinte.

A segunda subseção analisa especificamente as definições extraídas diretamente do segundo grupo de autores selecionados de acordo. Para tal verificação, realizou-se um levantamento, organizado como um inventário, do termo documentação com uso de uma ficha de coleta terminológica. O uso da ficha restringiu-se a sistematizar a coleta dos termos para análise qualitativa dos possíveis traços distintos ou convergentes entre os universos teóricos estudados, sem a intenção de propor novas definições. Em seguida, foram realizadas análise e sistematização, com vistas a verificar em que medida tendências, perspectivas ou abordagens teóricas e metodológicas surgiram no âmbito do CIDOC, da Europa, com preponderância do Reino Unido e Espanha, Estados Unidos e Brasil, entre as décadas de 1950 e 2000. Nesta subseção também foi incorporado um quadro comparativo entre as disciplinas dos cursos de graduação e pós-graduação em Museologia, atualmente em funcionamento no Brasil, que possuem o termo documentação em seus títulos, complementando a análise sobre as variadas 
apropriações do mesmo dentro do próprio Brasil, o que dá outros subsídios para a pesquisa.

O terceiro tópico do capítulo busca apurar as informações apresentadas nas outras duas partes, e tecer considerações preliminares a respeito do que pode ser chamado de documentação no contexto dos museus, tendo em vista o discutido no presente capítulo. A análise também envereda pela problematização entre o que foi consolidado nesta seção e a discussão em torno do objeto de museu como documento. Nesse ponto, foram levantados os desafios que ainda persistem para 0 desenvolvimento da documentação no contexto dos museus e quais as lacunas e as possibilidades de aproximação entre a Documentação, a Ciência da Informação e a Museologia.

\subsection{Apontamentos históricos sobre a documentação em museus}

A documentação é uma atividade realizada pelos museus desde os princípios de sua história moderna, com diferentes objetivos, métodos e formas (MARÍN TORRES, 2002; OLCINA, 1970). Marín Torres (2002) chama a atenção para o fato de que a realização da documentação de coleções possui raízes antes do surgimento dos museus tal como são conhecidos desde a modernidade. Em outras palavras, para estudar as práticas documentárias e os significados de cada conceito a elas associados, desde a década de 1950 até a década de 2000 na Europa, Estados Unidos e Brasil, é ponto fundamental entender a sua história - que está imbricada, necessariamente, com a história institucional dos museus. Essa história vai desde os gabinetes de curiosidades até os museus na contemporaneidade com sua complexa definição enquanto conceito e como instituição, conforme apresentado no segundo capítulo.

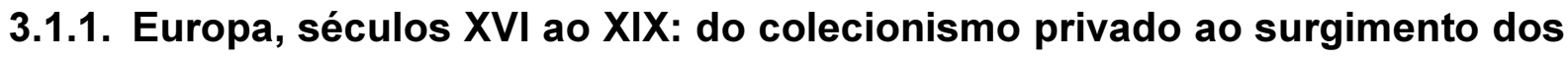 museus modernos}

Marín Torres (2002) explica que a necessidade de registro para organização da informação de coleções é uma ação que remonta aos templos da Grécia Antiga, quando os sacerdotes precisavam realizar controle das oferendas feitas aos deuses pelos civis. Desse modo, ela é uma atividade cuja origem se encontra no 
colecionismo de ordem privada, feita para fins de controle físico dos bens. Além dessa característica, para a autora, essa organização de caráter documental, que poderia se traduzir principalmente na confecção de inventários, era uma ação feita de acordo com os critérios particulares dos colecionadores, refletindo, assim, sua lógica ou visão de mundo. Vale salientar que durante períodos tão remotos, não se tratava ainda de uma discussão propriamente dita em torno da noção de documentação, mas sim de fazê-la seguindo um propósito específico.

Durante o século XVI, na Europa, um determinado tipo de instrumento de registro tornou-se bastante popular entre colecionadores privados: os catálogos. Em sua maioria, eram resultantes de extensos trabalhos de inventário e orientados, em parte dos casos, para demonstrar o poder dos donos, ou para fins comerciais. Marín Torres (2002) salienta que nesse período os catálogos começaram a ser feitos de modo a incorporar ilustrações, o que só se tornaria uma prática amplamente usada no século XVII. A ampliação do uso de ilustrações deu um caráter menos erudito e mais didático aos catálogos e foi decorrência direta de abertura à visitação de coleções de nobres e da realeza.

No século XVIII, inventários, catálogos e até mesmo guias de visitação ainda persistiram como elementos da documentação de coleções, principalmente aquelas de perfil artístico. Acerca desses tipos de documentos, Marín Torres (2002) aponta a confusão existente entre eles, sobretudo no que se refere ao formato, finalidade e tipo de informação disponibilizada. Apesar da confusão, ela salienta que os processos ou procedimentos de registro utilizados nesses documentos ainda são basicamente os mesmos realizados pelas instituições museológicas na contemporaneidade: aquisição, tratamento e difusão da informação. Pode-se supor que esse seja o maior indício de que o século XVIII é o principal marco para a consolidação da ideia de documentação dentro do universo da prática dos museus tal como se conhece hoje.

No final desse mesmo século, com o processo de mudanças social, política e econômica decorrentes da Revolução Francesa, a Europa ganhou impulso no que se refere à estruturação de uma área de patrimônio, incluindo-se os museus. Houve o surgimento, no âmbito dos grupos revolucionários, da ideia de apropriação e proteção dos monumentos e bens - que haviam escapado da destruição - como forma de instrumentalizar e valorizar um "projeto de nação". Nesse caso, a preservação dos bens resultaria em sua consagração como monumentos nacionais 
(CHOAY, 2001), exercendo ao mesmo tempo o caráter de troféu de conquista (LARA FILHO, 2013).

Nesse espírito que o Museu do Louvre foi aberto à visitação em 1793 para concentrar todas as coleções e bens da realeza deposta, consagrando a derrota desta e o discurso legitimador do novo regime. O objetivo era expor os bens como elementos de orgulho nacional e vocacionar o museu como espaço de educação do povo a respeito da identidade francesa. É válido destacar que, apesar disso, o entendimento de "abertura ao público" não implicou no livre acesso de todos às obras, pois a instituição manteve horários restritos e regras de etiqueta comportamental para realização de visitas - reproduzindo, assim, posturas anteriores ao Louvre aberto ao público. Segundo Lara Filho (2013), a inovação principal do Louvre foi trazer outra forma de discussão e apresentação das obras do acervo, apresentando-as em escolas artísticas. Era o início de uma abordagem sobre a história da arte que enfocava seus aspectos visuais, e não apenas cronológicos, como até então fora privilegiado nos museus e galerias de arte existentes - o que o torna o principal exemplo da ideia moderna de museu. Segundo Alexander (1979), essa concepção dos museus como instrumentos para a glória nacional persistiu no imaginário dos europeus, sendo também parte da configuração da ideia contemporânea de museu.

Alexander (1979) também destaca que no século XVIII, com a descoberta das leis de funcionamento do universo e da humanidade, os museus passaram a ser vistos como os lugares de preservação dos espécimes naturais, assim como das criações humanas, artísticas ou científicas. Esse direcionamento, tal qual no caso de museus que se destinam a expor elementos históricos de uma nação, persegue os ideais de educação e iluminação da mente humana, relacionados ao racionalismo acadêmico do período. Isso é, além de funcionar como espaço de salvaguarda de uma identidade nacional, os museus também veiculavam ideias sobre o progresso da humanidade, não em uma perspectiva excludente, mas, sobretudo complementar.

Na Europa, ao final do século XIX, com a consolidação do museu como instituição aberta ao público, a documentação tornou-se uma atividade de extrema importância nos museus. A crescente profissionalização dessas instituições ocorrida no período gerou postos e cargos específicos para a salvaguarda das coleções, definidos pelo seu alto grau de especialização. É nesse contexto que surgiria a 
profissão de conservador de museus na França, e aconteceria a divisão mais precisa entre as atividades de natureza intelectual, inventário e catalogação, e de natureza manual, traslado e instalação das obras, junto às coleções.

Com o crescimento do número de museus e o aumento significativo das coleções, o contexto profissional europeu conheceu uma demanda significativa por maior controle e padronização dos registros das coleções. Foi o início do movimento da diluição das lógicas privadas de curadores e ex-colecionadores na documentação dos acervos dos museus, até então predominantes, e a introdução da lógica da racionalização de procedimentos e informações sobre as coleções, que surge com força no século XIX, ainda que com sucesso muito variado. Data desse período também a maior organização da área de museus nos países da Europa, em que se destacam o modelo de administração do universo anglo-saxão, profundamente marcado pela manutenção das instituições por associações profissionais, ou entidades locais, e o modelo de administração espanhol, fortemente marcado pelo vínculo com a estrutura burocrática e legislativa governamental (MARÍN TORRES, 2002).

Segundo Alexander (1979), a preocupação com os modos de exposição dos objetos foi algo característico no universo dos museus no século XIX, o que só reforça o argumento de que a atividade de documentação ganhou nova proporção no cotidiano dos museus, tendo em vista a necessidade de produzir legendas e catálogos. Inicialmente, as mostras eram organizadas de modo a beneficiar os especialistas - os estetas, os acadêmicos, o colecionador - e não o grande público, o que somente começou a mudar no período em questão. Segundo o autor, muitos museus passaram a organizar as salas por períodos ou halls que davam ao visitante a sensação de atravessar diferentes estágios da história nacional - abordagem que se mostrou bastante adequada ao novo estilo moderno de vida, marcado pela democratização crescente da informação.

A preocupação com a normalização dos registros das coleções, principalmente dos catálogos de obras de arte, e com as formas de classificação e indexação chegou a estar presente nas agendas inicias de discussão de associações profissionais da área de museus, muitas das quais surgiram no período, como a Associação Britânica de Museus (MARÍN TORRES, 2002). Os governos de alguns países - dentre eles, Espanha e França - passaram a discutir normas e regras específicas para preservação do patrimônio histórico e artístico. Tal 
preocupação envolvia também a especificação de parâmetros mínimos de identificação das peças nas legendas expositivas e catálogos, com vistas ao acesso dos visitantes às informações.

\subsubsection{Século $X X$ : surgimento das primeiras iniciativas internacionais}

Segundo Marín Torres (2002), seria necessário esperar o clima de cooperação internacional do pós Primeira Guerra Mundial para que surgisse a primeira iniciativa de caráter supranacional e integradora para a área de museus, a saber, a Oficina Internacional de Museus - OIM -, que funcionou de 1927 a 1945. A OIM nasceu na Europa, vinculada à Liga das Nações, também criada na Europa no pós Primeira Guerra Mundial com o objetivo de funcionar como organismo de intermediação entre os países, e evitar novos conflitos. Tinha por objetivo elaborar um padrão definitivo para a normalização dos catálogos das coleções, de modo a facilitar a movimentação de obras de arte entre os museus de vários lugares do mundo. Tal objetivo estabeleceu-se também como forma de proteger e, em alguns casos, recuperar coleções de museus na Europa que haviam sido desarticuladas ou removidas de suas instituições por causa da guerra.

Apesar do objetivo louvável, Marín Torres afirma que o projeto da OIM não logrou um consenso possível entre os museus europeus. A falha se deu, segundo a autora, porque diretores de algumas das maiores instituições da Europa foram contra o projeto, por julgarem que cada museu deveria estabelecer suas regras ou mesmo realizar inventários nacionais antes de se estabelecer uma normativa internacional para os acervos. Apesar da reação contrária, a iniciativa teve a vantagem de conseguir promover discussões entre diferentes profissionais de museus a respeito das práticas realizadas por suas instituições (MARÍN TORRES, 2002).

No entreguerras é válido destacar a consolidação das ideias de Paul Otlet e Henri La Fontaine, conforme apresentado no segundo capítulo. Para eles, a aplicação das técnicas documentárias auxiliaria os museus a organizarem o crescimento exponencial das coleções, permitindo a sua integração com outros tipos de documentos e principalmente, sua exposição. Ambos entreviam nos museus um organismo documental, tendo em vista o seu potencial enquanto instituição de 
educação e acesso à informação, e ao que denominavam de realidade objetiva da sociedade (OTLET, 1937).

Marín Torres (2002) ainda ressalta que o momento pós Segunda Guerra Mundial testemunharia o ressurgimento de projetos de natureza internacional, devido ao novo alento com o desenvolvimento de algumas tecnologias de comunicação. Nesse contexto histórico, a autora ressalta o nascimento da disciplina de documentação - ou, de acordo com o exposto no segundo capítulo, o seu desenvolvimento na Europa e Estados Unidos - como um marco importante. Aqui vale ressaltar que, apesar de a autora utilizar o termo documentação, compreendese, pelo contexto,que ela se refere, de fato, à disciplina Documentação. Por necessidade de respeitar o contexto original do texto, a grafia utilizada é mantida. Para ela, a disciplina foi responsável por suprir a necessidade das instituições de organizarem fontes de informação e subsidiarem o acesso de pesquisadores. $O$ mesmo se deu com os museus, tendo em vista o crescimento acelerado de suas coleções e a necessidade de controle sobre elas - como já havia entrevisto Paul Otlet em 1934, no Traité.

Em 1946 foi criado o Conselho Internacional de Museus - ICOM -, com sede em Paris, França, sendo herdeiro direto das discussões e projetos da OIM. Alguns anos depois, em 1950, foi instituído o seu Comitê Internacional para Documentação - CIDOC -, que se preocupou desde o início com as discussões sobre padronização de formas de registro e identificação das peças que pudessem ser utilizadas em nível internacional (CERAVOLO; TÁLAMO, 2007). Porém, muito embora o ICOM e o CIDOC tenham nascido como instâncias internacionais, a predominância de profissionais europeus em sua estruturação - nesse início, com maior destaque aos franceses - é algo que marcará não só esse primeiro momento de vida institucional de ambos, mas também as décadas seguintes.

É válido destacar a atuação, nos primeiros anos do CIDOC, da bibliotecária e documentalista francesa Yvonne Oddon. Ela coordenou durante longos anos as atividades iniciais do Centro de Documentação da UNESCO-ICOM, que tinha base em Paris, França. Por uma questão regulamentar do ICOM à época, a coordenação do Centro de Documentação da UNESCO-ICOM era indicada para secretariar o CIDOC (OLCINA, 1986). Devido a esse vínculo, ela foi responsável pela realização de cursos sobre documentação em museus e, durante sua longa atuação como secretária do CIDOC, criou modelos padronizados de fichas catalográficas e 
inventários. Apesar do esforço, a implantação de vários desses modelos também não foi possível devido às inúmeras variações de procedimentos existentes entre os museus participantes das atividades do CIDOC - sendo que alguns deles eram não europeus (OLCINA, 1986).

No término da década de 1960, o CIDOC já havia se consolidado como organismo de referência sobre documentação em museus. Nesse período, sua atuação passou a contar com a estruturação de diferentes grupos de trabalho para discussão de temas julgados essenciais para a documentação em museus: terminologia, bibliografia e documentação de coleções em museus. A composição de grupos de trabalho também viria na esteira da necessidade de tornar a participação dos profissionais mais engajada para conseguir internacionalizar, de fato, o CIDOC. Na década seguinte, o Comitê se dedicou a identificar as necessidades de informação de cada área ou disciplina de base dos museus, de modo a caracterizar um conjunto mínimo de dados para gerenciamento dos acervos (MARÍN TORRES, 2002; OLCINA, 1986).

Outro evento importante ocorrido durante o final da década de 1960, e ao longo das décadas de 1970 e 1980, foi o avanço da informática (CERAVOLO; TÁlAMO, 2007). Para Ceravolo e Tálamo (2007), os profissionais de museus dedicados a discutir sobre documentação de museus não se furtaram à crença de que a informática poderia resolver todas as questões de organização, tratamento, recuperação da informação e composição de catálogos. Apesar de a informática ter contribuído para automatizar os processos, com o passar dos anos ficaria claro que não seria ela sozinha capaz de resolver as questões de ordem conceitual e metodológica da documentação em museus. Desse modo, o uso das novas tecnologias acabou introduzindo novas discussões para a documentação, como o próprio questionamento acerca do papel de seu uso nos museus.

$\mathrm{Na}$ década de 1990, a iniciativa do CIDOC citada anteriormente seria concluída. Nessa década, um grupo de trabalho especial foi montado para se dedicar ao assunto, com membros de outros grupos de trabalho do CIDOC e de instituições como o então denominado Getty Information Institute ${ }^{5}$, dos Estados Unidos. Após anos de trabalho conjunto, as instituições conseguiram lançar, em junho de 1995, a publicação intitulada Internacional Guidelines for Museum Object

\footnotetext{
${ }^{5}$ Atual Getty Research Institute.
} 
Information: The CIDOC Information Categories (CIDOC-ICOM, 1995) ${ }^{6}$ - referência que constitui o objeto empírico desta pesquisa. Este documento apresentou os propósitos da documentação no contexto dos museus e propôs 22 categorias de informação que representam os grupos de dados que devem ser observados e descritos no momento do registro dos acervos. O detalhamento da história de atuação do CIDOC e da elaboração das Guidelines será feito no quarto capítulo da dissertação, dedicado à análise das referências que constituem o objeto empírico da pesquisa.

\subsubsection{Europa: as experiências do Reino Unido e Espanha}

Como destacado no tópico anterior, a Europa foi o espaço de surgimento e consolidação do modelo de museu moderno ao longo do século XIX, que influenciou toda uma geração de instituições ao redor do mundo, incluindo aqueles que seriam estabelecidos na América. A Europa também foi o berço de criação das primeiras iniciativas de caráter internacional pensadas no âmbito de uma área profissional de museus, como foi o caso da OIM e do seu herdeiro, o ICOM. Além disso, vale destacar duas experiências no contexto do cenário europeu: o Reino Unido e a Espanha. Outros países, como França e Itália, também possuem experiências importantes e de longa data, associadas a seus respectivos Ministérios da Cultura no que se refere à documentação em museus e do patrimônio em geral, mas que não serão comentadas aqui por não se incluírem nos recortes definidos para o presente trabalho.

No caso do Reino Unido, é possível destacar o pioneirismo de sua Associação Britânica de Museus e a sua diferenciação no que tange o modelo de administração dos museus como uma das bases para sua escolha (MARÍN TORRES, 2002), além da sua pertinência frente aos critérios de seleção de autores estabelecidos para este trabalho. Outro fator que destaca o Reino Unido é sua histórica preocupação com as questões relacionadas à documentação dos acervos dos museus, em grande parte pela necessidade cada vez maior de prestar contas à sociedade a respeito dos recursos gastos com as coleções e os profissionais dos museus (ROBERTS, 1985). Além disso, nos anos de 1970, foi criado o grupo

\footnotetext{
${ }^{6}$ Disponível em: <http://network.icom.museum/cidoc/resources/cidoc-standards-guidelines>. Acesso em: 12 abr. 2014.
} 
Information Retrieval Group of the Museum Association - IRGMA - pela Associação Britânica de Museus. Esse grupo, que tinha por finalidade estudar as formas de recuperar informações sobre os acervos dos museus, logo se transformaria em uma organização chamada Associação para Documentação de Museus - em inglês, Museum Documentation Association I MDA - (MARÍN TORRES, 2002). Em 2008, a MDA passaria por novo processo de reestruturação, passando a se chamar Collections Trust.

A experiência iniciada pelo IRGMA traz um papel de destaque para o Reino Unido na história da documentação em museus. O grupo pode ser considerado praticamente a primeira organização que produziria sistematicamente ao longo de vários anos uma série de normativas, encontros e seminários voltados para 0 assunto. Essa sistematização não encontraria precedentes em outras regiões da Europa tão brevemente, o que permitiu ao grupo, e depois à Associação, ter atuação semelhante ao próprio CIDOC em termos de articulação de profissionais, credibilidade na área e divulgação de parâmetros.

Durante a década de 1980 e início de 1990, a MDA realizou uma série de eventos sobre documentação em museus e publicou referências sobre padrões de catalogação para diferentes tipologias de objetos. Na década de 1990, a MDA passaria a se preocupar cada vez mais com a terminologia utilizada para tratamento da informação dos acervos, tendo em vista a necessidade de fornecer informações consolidadas e consistentes para públicos internos, órgãos fiscalizadores e sociedade em geral. Tal preocupação, segundo Ceravolo e Tálamo (2007), estava em convergência com as preocupações internacionais da área de museus que marcaram a década.

Em 1994, a MDA lançou uma norma denominada SPECTRUM - Standard Procedures for Collections Recording Used in Museums -, que consolidou uma série de recomendações sobre gestão de coleções lançadas nos anos anteriores. Atualmente, a norma se encontra em sua versão 4.0, publicada em 2011 (COLLECTIONS TRUST, 2011b). A norma também trouxe sua interpretação sobre os objetivos da documentação nos museus, tornando-se assim uma referência internacional tal como as CIDOC Guidelines. Vale salientar que o detalhamento da história da SPECTRUM será retomado no quarto capítulo, sendo aqui citada apenas para subsidiar a criação de um contexto mais amplo da situação europeia, no que se refere ao assunto documentação em museus. 
O destaque à Espanha é devido ao pioneirismo de seu governo na implantação de leis específicas para a área de museus, regulando particularmente a produção de inventários e registros documentais sobre as coleções (MARÍN TORRES, 2002). Segundo Marín Torres, os primeiros museus se estabeleceram tardiamente no país, mas desde o início houve preocupação com a estruturação de uma área profissional capacitada e integrada para atuar nas instituições particularmente no que se refere à documentação dos acervos. A autora exemplifica tal situação com a seguinte citação:

Toda evolução legislativa espanhola no século XIX vem a demonstrar a importância que os instrumentos documentais vão adquirindo dentro dos museus e a necessidade de uma maior uniformidade através de regulamentos que fossem aplicados por um corpo profissional cada vez melhor formado. (MARÍN TORRES, 2002, p. 218. Tradução da autora).

A esse respeito, destaca ainda que nem sempre a reverberação das orientações legislativas na prática e na formação profissional aconteceu de modo fácil, devido à dificuldade decorrente da ausência de normas e padrões - e da consequente demanda pela compatibilização de informações a partir disso. Ressalta ainda que os museus arqueológicos encabeçaram a aplicação das novas técnicas para administração das coleções, muito em parte pelo tamanho de suas coleções e a urgência em organizá-las de forma adequada.

Já no século XX, especificamente a partir da década de 1980, é válido destacar a atuação do Ministério da Cultura do país. É nesse período que nasce o projeto de Normalización Documental de Museos, que ganhou uma publicação no ano de 1998. O objetivo do projeto, e posteriormente da publicação, foi apresentar uma série de pressupostos legais, princípios e estruturas para a organização documental dos museus pertencentes ao Ministério. A publicação previu princípios para o desenvolvimento de uma base de dados e para os procedimentos de gestão das coleções. Nos últimos anos, esse projeto permitiu a criação de outras iniciativas de integração das coleções dos museus da Espanha pertencentes ao Estado, como a Colecciones en $\operatorname{Red}^{7}$, que disponibiliza a busca pelos catálogos dos acervos em uma plataforma única e com descritores padronizados indicados ao interessado.

Outro aspecto importante a ser destacado a respeito dos contextos anglosaxão e espanhol tem a ver com a organização dos cursos de formação para

\footnotetext{
${ }^{7}$ Disponível em: <http://ceres.mcu.es/pages/SimpleSearch?index=true>. Acesso em: 15 jan. 2014.
} 
profissionais de museus. Acredita-se que o entendimento teórico que tais cursos passam a dar para uma atividade oriunda do universo da prática dos museus - a documentação - é outro ponto central para a compreensão da relação entre as ideias e práticas existentes na atualidade em torno desse fazer. Cumpre apenas uma última ressalva sobre o assunto: os cursos que serão comentados surgem, em sua maioria, posteriormente à inserção da documentação como atividade cotidiana de museus. Ou seja, apesar da reciprocidade esperada e existente entre os universos da prática e da teoria, o diálogo da história da documentação, enquanto um fazer de museu, nem sempre será consensual com a história do conceito de documentação elaborado teoricamente pelos cursos de formação.

No contexto anglo-saxão, os cursos de formação se denominam Museum Studies e são, em sua maioria, de pós-graduação lato e stricto sensu ${ }^{8}$. Conforme explica Ceravolo (2004), surgiram na década de 1980 e tiveram forte influência do estruturalismo, tal como ocorreu com outros grupos europeus que surgiram no período. Salienta-se que a discussão sobre a documentação nesses cursos foi direcionada para o aprimoramento das questões práticas das instituições, cabendo às disciplinas como Antropologia, Arqueologia, Semiótica, Arte, entre outras, as discussões teóricas a respeito da significação dos acervos e a crítica ao fazer documental. Tais cursos não se interessavam, por exemplo, pela discussão da Museologia como disciplina científica ou como base teórica para a discussão sobre documentação, o que é um dado que será retomado posteriormente neste capítulo.

As exceções desse caso talvez sejam a Espanha e França, países onde a Museologia é compreendida como disciplina de estatuto independente. Particularmente na Espanha, é possível identificar que a documentação em museus é considerada uma atividade cuja base teórica provém da Museologia. Tais cursos são em sua maioria de pós-graduação, geralmente stricto sensu ${ }^{9}$. Em determinados casos, a Museologia é entendida como uma das ciências da documentação ${ }^{10}$, mas em outros, está ligada ao universo das Artes e da Arqueologia, o que leva ao entendimento de que a concepção de documentação em museus poderá ser

\footnotetext{
${ }^{8}$ Disponível em: <http://www.museumsassociation.org/careers/8326>. Acesso em: 15 jan. 2014.

${ }^{9}$ Disponível em: <http://www.mcu.es/museos/CE/RecProf/Formacion.html>. Acesso em: 15 jan.2014.

${ }^{10}$ Ver item 2.1.3 (p.28-33, Capítulo 2).
} 
igualmente diferente - o que também será possível verificar no inventário sobre a definição do termo que será apresentado mais adiante.

\subsubsection{América: Estados Unidos e Brasil}

O estabelecimento dos museus no continente americano remonta aos finais do século XVIII e todo o século XIX. A maioria desenvolveu-se a partir de coleções particulares ou de estudo científico, sendo essas últimas mantidas principalmente pelos impérios europeus que possuíam colônias na região (BUCK; GILMORE, 2010; LOPES, 2009). Da mesma forma que no caso da Europa, existem várias experiências importantes nesse contexto, no que se refere à história dos museus e da documentação já no século $X X$, como os casos do Canadá na América do Norte, e do Chile, Colômbia e Argentina na América do Sul, por exemplo.

No caso do Canadá, é possível citar a existência da Canadian Heritage Information Network, que existe desde 1972. É a principal instância de fomento ao intercâmbio de informações entre os museus canadenses, por meio do uso de tecnologias inovadoras ${ }^{11}$. Já nos países da América do Sul, é possível mencionar o projeto SUR - Sistema de Registro Integrado - desenvolvido desde 1995 pelo Centro de Documentación de Bienes Patrimoniales ${ }^{12}$, órgão vinculado à Subdirección Nacional de Museos da Dirección de Bibliotecas, Archivos e Museos do Governo do Chile. Do mesmo modo, é possível citar o trabalho da Dirección de Patrimonio do Ministerio de Cultura de la Republica de Colombia ${ }^{13}$, que possui diversas ações de normalização de inventário iniciadas no final da década de 1990. Na Argentina, há que se destacar o trabalho da Dirección Nacional de Patrimonio y Museos de la Secretaría de Cultura de la Nación, que com seu Servicio Nacional de Inventarios de Patrimonio - SENIP - se propõe a informatizar os dados das coleções museológicas e de documentos históricos. Os dados das coleções das instituições participantes já se encontram disponíveis pelo portal do SENIP ${ }^{14}$. Mas,

\footnotetext{
11 Disponível em: <http://www.rcip-chin.gc.ca/apropos-about/histoire-history/index-eng.jsp>. Acesso em: 16 mar. 2014.

${ }^{12}$ Disponível em: <http://www.cdbp.cl>. Acesso em: 05 jan. 2013.

${ }^{13}$ Disponível em: <http://www.mincultura.gov.co/>. Acesso em: 10 ago. 2011.

14 Disponível em: <http://www.cultura.gob.ar/acciones/servicio-nacional-de-inventarios-de-patrimoniosenip/>. Acesso em: 24 mar. 2013.
} 
para efeito deste trabalho, serão comentados, em maior detalhe, os casos dos Estados Unidos e Brasil.

Entre o final do século XIX e o início do XX, os museus estadunidenses se consolidaram como instituições destinadas à educação e ao esclarecimento do público. A esse respeito, Oroz (2002) discute o estabelecimento do American Compromise, paradigma fundamental para entender o movimento dos museus nos Estados Unidos entre 1850-1870 e o desenvolvimento posterior dessas instituições no país. Entre essas duas décadas, devido a fatores diversos - sendo a Guerra Civil entre 1861 e 1865 um dos mais marcantes - o American Compromise trouxe equilíbrio entre o desejo de parte da população por maior profissionalização do país e as intenções da parte que almejava os benefícios da educação popular. Segundo - mesmo autor, a educação popular era entendida como uma das principais estratégias para garantir a igualdade de chances entre as pessoas, de modo a estimular uma competição justa. Isso era algo defendido por muitos como um contraponto ao profissionalismo, ainda calcado em saberes especializados e conhecidos por poucos, tido como algo por vezes sem razão de ser frente a cenários de racionamento de suprimentos e guerra civil.

Durante esses anos, várias instituições norte-americanas de pesquisa acadêmica - como o Smithsonian Institute - viram-se diante da necessidade de justificar sua utilidade para uma sociedade fortemente convulsionada. Coube às Academias de Ciência, Ateneus e outras instituições afastarem sua imagem e suas práticas da ideia de elitismo, a partir da transformação de suas coleções em museus, com acesso ampliado ao público em geral.

Para Oroz (2002), com o fim da Guerra Civil, muitos cidadãos americanos começaram a se preocupar com a preservação da herança norte-americana dos tempos da Independência, cuja garantia de execução era ligada à educação popular. A vinda ou a organização de exposições internacionais nos Estados Unidos também popularizou o acesso a pessoas que nunca tinham visitado um museu antes, o que igualmente reforçou as pressões que culminaram na ampliação da abertura das coleções de vários museus ao público. Foi neste período, então, que se configurou o modo como os museus norte-americanos atuam, de forma a manter uma preocupação com os estudos profissionais, ao mesmo tempo em que valorizam fortemente a educação popular. 
Alexander (1979) ressalta que os museus norte-americanos continuam a destacar-se com seus programas educacionais, geralmente se referindo à educação como "interpretação", isto é, ensinar através do uso de objetos originais. Tal configuração se dá porque a interpretação, segundo a abordagem do autor, recai fortemente no pressuposto do uso da percepção sensorial para habilitar emocionalmente o visitante de museu a ter a experiência com os objetos. $O$ autor ressalta as relações muito próximas que os museus americanos desenvolveram com as escolas, o que dá a entender que o público escolar é priorizado no trabalho desenvolvido por essas instituições.

No que se refere à documentação em museus, é possível citar o trabalho desenvolvido pela Associação Americana de Museus ${ }^{15}$, fundada em 1906. Desde seus primeiros anos, a Associação se preocupou com a organização e padronização de cursos de formação específica para os profissionais de museus, incluindo aqueles dedicados à atividade de registro das coleções - registration. Com o passar dos anos, passou a se dedicar também ao estabelecimento de regras mínimas para a salvaguarda das coleções, que culminou com o lançamento em 1959 da primeira edição da publicação Museum Registration Methods. Tal publicação é um manual de boas práticas de trabalho de gestão de coleções amplamente difundido nos Estados Unidos, atualmente, encontra-se em $5^{\text {a }}$ edição, lançada em 2010.

Outro exemplo relativo à discussão sobre documentação é o trabalho do Getty Research Institute, intitulado Art and Architecture Thesaurus - AAT. O início do projeto do tesauro data dos anos 1970, transformado nos anos $1980^{16} \mathrm{em}$ um departamento específico para gerenciamento do programa dentro do Instituto. Nos anos 1990, o vocabulário foi publicado pela primeira vez. Desde então, a iniciativa é reconhecida como uma das maiores experiências exitosas em construção e difusão de vocabulário controlado para a área de museus.

Criado para atender as questões das áreas de artes e arquitetura, o AAT é passível de ser aplicado, em certo nível, ao patrimônio cultural como um todo. $O$ tesauro também apresenta uma estrutura multilíngue e classifica as manifestações artísticas de uma perspectiva multifacetada, não restringindo-as somente à

\footnotetext{
${ }^{15}$ Atualmente, sua designação é Aliança Americana de Museus - The American Alliance ofMuseums. Disponível em: <http://www.aam-us.org/about-us>. Acesso em: 16 jan. 2014.

${ }^{16}$ Disponível em: <http://www.getty.edu/research/tools/vocabularies/aat/about.html>. Acesso em: 11 fev. 2013.
} 
tradicional divisão por períodos ou técnicas. Além do AAT, o Getty Research Institute possui outros vocabulários estruturados, como o The Cultural Objects Names Authority - CONA -; The Getty Thesaurus of Geographic Names - TGN -; The Union List of Artist Names - ULAN. Há também um modelo amplamente difundido internacionalmente de catalogação de obras de arte chamado Categories for Description of Works of Art - CDWA - que começou também a ser produzido nos anos 1990.

Como já dito, a área de museus na América do Sul, da mesma forma que a do Norte, foi marcada nos primeiros anos pelo estabelecimento de relações dos museus com a pesquisa científica em história natural e etnologia (SUANO, 1986). Já as últimas décadas do século $\mathrm{XX}$ seriam marcadas por alterações significativas, com a participação ativa de países não só da América do Sul, mas da América Latina inteira, em movimentos que mudaram os rumos da atuação dos museus de diferentes temáticas na região - a exemplo da realização da Mesa Redonda de Santiago do Chile, organizada pelo ICOM em 1972.

Nesse evento, a principal pauta foi a crítica ao modelo europeu e tradicional de museu - uma instituição ainda muito vinculada à ciência e aos discursos ideológicos pouco representativos da realidade latino-americana. É importante dizer que esse questionamento existente em torno do museu e debatido durante a Mesa Redonda teve raízes em movimentos religiosos, sociais e políticos de contestação da ordem política estabelecida, marcada por ditaduras militares no governo de vários dos países participantes do evento, incluindo o Brasil. A Mesa Redonda culminou em uma declaração que se tornaria referência para os museus não só da região, mas de outros lugares do mundo, devido à proposição do conceito de "museu integral", em contraposição à ideia de museu em moldes europeus.

O museu integral seria aquele articulado à dinâmica social das comunidades onde se encontra, e com forte poder de liderança em processos de desenvolvimento social, particularmente necessário na América Latina. Em muitos lugares, as pequenas e médias instituições iniciaram a realização de trabalhos de base de preservação in situ do patrimônio das comunidades, envolvendo o desenvolvimento de programas de ação educacional (VARINE, 2000). Nesse sentido, é possível dizer que o museu integral, na medida em que propunha o afastamento dos ideais europeus, deveria se direcionar menos para atividades de conservação e 
documentação, procurando contrabalançá-las com as de maior cunho educacional e social.

Paralelamente, a partir da década de 1980, vários trabalhos e projetos relacionados à documentação de acervos apareceram na região, em especial no Brasil. A maioria apresenta como ponto forte da iniciativa a possibilidade de fornecer subsídios para o reconhecimento do patrimônio nacional/regional a favor de sua própria população, mas tem como fundamento inicial a urgência de identificar os bens culturais preservados e protegê-los de problemas como tráfico ilícito.

No Brasil, é possível citar o trabalho de consolidação de orientações para a documentação de acervos museológicos feito por Fernanda Camargo-Moro, Museu: documentação/aquisição, publicado em 1986. O livro vigora até hoje como uma das principais e poucas referências de maior fôlego produzidas e lançadas no país sobre o assunto. Em 1987, a extinta Fundação Pró-Memória do Ministério da Cultura publicou Thesaurus para acervos museológicos (FERREZ; BIANCHINI, 1987), que continua sendo uma referência muito utilizada até os dias de hoje e, embora careça de atualização, é o único vocabulário controlado existente no Brasil sobre objetos, feito exclusivamente para acervos de museus. Em 1995 foi lançado o Manual de catalogação: pintura, escultura, desenho e gravura (FERREZ; PEIXOTO, 1995) pelo Museu Nacional de Belas Artes, do Ministério da Cultura. A publicação, a exemplo das outras duas mencionadas, é uma das poucas referências publicadas no Brasil sobre parâmetros de descrição física de tipologias específicas de acervo.

Cumpre ressaltar, do mesmo modo, o trabalho de Inventário de Acervos Museológicos da Secretaria de Estado da Cultura de Minas Gerais, realizado através de sua Superintendência de Museus, relatado pela historiadora, à época superintendente de Documentação e Informação do IEPHA/MG, Maria Inês Cândido na publicação Caderno de Diretrizes Museológicas 1 (CADERNO DE DIRETRIZES, 2006). A publicação, lançada em 2006, foi uma parceria entre o Governo do Estado de Minas Gerais e o Departamento de Museus do Instituto do Patrimônio Histórico e Artístico Nacional.

Em 2009, o Departamento de Museus supracitado foi transformado em Instituto Brasileiro de Museus, iniciando uma nova fase na administração de políticas públicas para a área. Data do mesmo ano o lançamento do Estatuto Brasileiro de Museus (Lei Federal $n^{\circ}$. 11.904/2009), que busca estabelecer algumas diretrizes para a documentação dos acervos dos museus, e passa a falar na realização do 
Inventário Nacional de Bens Musealizados. O Estatuto foi recentemente regulamentado por meio do Decreto Federal $n^{\circ}$. 8.124/2013, sendo o Inventário uma de suas pautas e objeto de indicação de novas regulamentações futuras.

Por último, vale ressaltar o trabalho da Secretaria de Estado de Cultura de São Paulo, que realizou entre 2008 e 2010, por meio de sua Unidade de Preservação do Patrimônio Museológico, o Projeto de Documentação dos Acervos Museológicos. A metodologia e execução do projeto são relatados na publicação lançada em 2010, Documentação e Conservação de Acervos Museológicos: diretrizes (SEC/ACAM Portinari). Além deste, destaca-se na cidade de São Paulo o trabalho da Secretaria Municipal de Cultura de São Paulo, com o lançamento em novembro de 2012 do Portal de Acervos Artísticos e Culturais da Prefeitura Municipal de São Paulo ${ }^{17}$, que centraliza as buscas nas diferentes coleções pertencentes aos organismos culturais municipais.

No que se refere à formação profissional, nos Estados Unidos os cursos de formação foram fundados, em sua maioria, no início do século XX e funcionaram em seus primórdios dentro dos próprios museus, com apoio da Associação Americana de Museus (BUCK; GILMORE, 2010). Da mesma forma que no Reino Unido, a formação se dá basicamente pelos programas de pós-graduação em Museum Studies, embora seja necessário ressaltar que, no contexto estadunidense, a ênfase no desenvolvimento dos programas de Museum Studies foi dada à elaboração de boas práticas de gerenciamento das coleções, particularmente derivadas das discussões em torno da gestão de monumentos e sítios arqueológicos (CERAVOLO, 2004). Nesse país há, assim, um amplo espectro de possibilidades de profissionalização para os interessados em atuar na área de museus - desde cursos mais práticos, até os com maior abordagem teórica ${ }^{18}$. Porém, é necessário salientar a predominância do viés prático do entendimento sobre documentação de acervos em museus.

No caso brasileiro, o primeiro curso de formação profissionalizante para a área de museus foi fundado em 1932 no Museu Histórico Nacional, vinculado à administração pública federal (SIQUEIRA, 2009). Durante muitos anos, esse seria o

\footnotetext{
17 Disponivel em: <http://www.acervosdacidade.prefeitura.sp.gov.br/PORTALACERVOS/>. Acesso em: 15 fev. 2013. O lançamento oficial ocorreu em 01/11/2012, de acordo com o portal de notícias da Secretaria Municipal de Cultura de São Paulo.
}

18 Disponivel em: <http://www.aam-us.org/resources/careers/career-management/professionaleducation>. Acesso em: 16 jan. 2014. 
único curso profissionalizante oficial, só se modificando a partir do final da década de 1960, com a fundação do curso de graduação em Museologia da Universidade Federal da Bahia e da Universidade Estácio de Sá, no Rio de Janeiro. No final da década de 1970, o curso do Museu Histórico Nacional alcançaria o status de universitário e seria transformado em graduação de Museologia. Nessa época, ele deixa o Museu Histórico Nacional para funcionar nas instalações da Federação das Escolas Federais Isoladas do Rio de Janeiro, hoje Universidade Federal do Rio de Janeiro - Uni-RIO.

É possível dizer que a formação de profissionais para a área de museus no Brasil se deu primeiro em uma perspectiva técnica, não nascendo necessariamente sob a égide da discussão teórica a respeito da pertinência de uma disciplina independente para isso - muito embora, tenha evoluído nesse sentido posteriormente. Nas últimas décadas do século $\mathrm{XX}$ e início do $\mathrm{XXI}$, a perspectiva acadêmica predominante consolidou a Museologia como a disciplina responsável pela formação para a área de museus no Brasil. Inclui-se no âmago de tal consolidação o aumento no número de universidades que oferecem, atualmente, o curso de graduação em Museologia e também de pós-graduação, nos níveis de mestrado e doutorado. No total, com parâmetro de junho de 2013, são 14 os cursos de graduação e 2 os programas de pós-graduação, a saber:

\section{Cursos de graduação}

1. Uni-RIO - Universidade Federal do Rio de Janeiro;

2. UFBA - Universidade Federal da Bahia;

3. UFRB - Universidade Federal do Recôncavo Baiano;

4. UNIBAVE - Universidade Barriga Verde - SC (privada);

5. UFPE - Universidade Federal de Pernambuco;

6. UNb - Universidade de Brasília;

7. UFG - Universidade Federal de Goiás;

8. UFSC - Universidade Federal de Santa Catarina;

9. UFRGS - Universidade Federal do Rio Grande do Sul;

10. UFPEL - Universidade Federal de Pelotas-RS;

11. UFMG - Universidade Federal de Minas Gerais;

12. UFOP - Universidade Federal de Ouro Preto-MG;

13. UFS - Universidade Federal de Sergipe; 
14. UFPA - Universidade Federal do Pará.

\section{Programas de pós-graduação stricto sensu}

1. Uni-RIO - Programa de Pós-Graduação em Museologia e Patrimônio/Mestrado e Doutorado;

2. USP - Programa de Pós-Graduação Interunidades em Museologia/Mestrado.

Nesses cursos e programas, a documentação de acervos está presente nas disciplinas dos currículos, como será possível ratificar na subseção 3.2, que apresenta o inventário do termo documentação. É possível inferir que, no Brasil, a documentação de acervos de natureza museológica - estejam eles no museu, ou não - não só é legalmente reconhecida como tarefa do museólogo, mas também referendada pela formação acadêmica. Nesse sentido, vale ressaltar o texto da Lei Federal $n^{\circ}$. 7.287/1984 que regulamenta a profissão de museólogo e consolida o entendimento da proeminência da Museologia como base para a formação profissional direcionada à área de museus. Ela delimita que uma série de atividades dessas instituições, incluindo a documentaçãol, é de domínio imediato e exclusivo do profissional museólogo - que teria, assim, um papel preponderante dentro dos museus e, igualmente, no âmbito do ensino e das discussões teóricas sobre as mesmas.

\subsubsection{Considerações preliminares a partir dos apontamentos históricos}

O cenário apresentado sobre Europa e América traz apenas exemplos que demonstram que a atividade de documentação foi alvo de diferentes abordagens e enfoques desde o surgimento do museu enquanto instituição pública, no século XVIII. Um aspecto que vale ser comentado acerca da apresentação de tais cenários e momentos históricos é que não se parte da compreensão de que a passagem do tempo implicou uma evolução linear das práticas, tampouco dos significados do termo. Pelo contrário, os contextos apresentados demonstram uma complexidade crescente em torno do assunto, envolvendo áreas diferentes e discussões a respeito das formações profissionais. 
É possível relacionar essa crescente complexidade com a própria discussão sobre o papel e função dos museus nessa sociedade, colocando em pauta a crítica às suas atividades cotidianas, como a documentação. Como visto no segundo capítulo, definir um museu nos dias atuais não é tarefa simples, pois a complexidade inerente a essa instituição também é crescente. É possível salientar que os contextos históricos abordados nesse capítulo refletem que tal complexidade se estende também para a definição de documentação em museus, enquanto prática e possibilidade de definição teórica.

Pelo apresentado até o momento, compreende-se que existe uma variação de entendimento e apropriação que marca o uso do termo documentação no contexto dos museus. A variação pode ser entendida como decorrente das especificidades culturais, sociais e históricas, e tendências de pensamento sobre essa atividade em cada contexto abordado. Desse modo, a variação é uma manifestação dos fenômenos linguísticos, em que os significados dos termos se conformam e alteram, conforme as características locais - Reino Unido, Espanha, Estados Unidos e Brasil -, relativizando qualquer entendimento que vislumbre uma univocidade de uso e interpretação. O caso do CIDOC, enquanto primeira iniciativa de sucesso de caráter internacional sobre documentação em museus, mostra uma intenção primeira de padronizar procedimentos e criar normas, mais do que refletir ou definir o que é documentação - o que não o afasta, portanto, dos outros contextos nacionais.

Todavia, a abordagem que relativiza o significado de documentação em museus não impede que se investigue o assunto. A pesquisa sobre o significado de documentação no contexto dos museus não implica a pretensão de alcançar uma única definição possível para o termo, o que seria teoricamente contraditório, de acordo com os pressupostos adotados por esse trabalho. Trata-se, antes, de compreender as estruturas e formas de organização dos usos do termo em cada contexto situacional, e comparar as características similares e peculiares de cada um, enquanto esforço de sistematização. Várias são as questões que podem ser estudadas a partir disso, de ordem prática e teórica. As indagações que interessam particularmente ao presente trabalho são de ordem teórica e podem ser resumidas nas seguintes perguntas: quais são os traços distintivos do termo nos contextos selecionados para este trabalho? Quais são os detalhes da relação entre teoria e prática em cada espaço e tempo que influenciam a conformação de tais traços? E é sobre elas que versará o próximo tópico. 


\subsection{Variações em torno do termo documentação no contexto dos museus}

Esta subseção apresenta o inventário do termo documentação no contexto dos museus, realizado a partir do material sistematizado com o uso de uma ficha de coleta terminológica. Aqui são abordadas as escolhas terminológicas de diferentes autores, bem como as definições que propõem. Como já dito anteriormente, o material registrado nas fichas foi selecionado a partir do critério da língua na qual o texto foi escrito - antes para verificar sua origem - inglês, espanhol e português, da sua cronologia - terem sido produzidos entre as datas-limite de 1950 e 2000 - e pela origem dos autores - CIDOC, Reino Unido, Espanha, Estados Unidos e Brasil. Nem todos os contextos selecionados e comentados no capítulo possuem textos ilustrativos de todas as décadas previstas no intervalo de tempo mencionado. As datas-limite servem, unicamente, para estabelecer um recorte cronológico para a análise qualitativa a respeito do uso do termo documentação no tempo e no espaço, em diferentes locais.

Vale a ressalva de que o caso do CIDOC será apresentado apenas como exemplo do que foi concebido como documentação nos seus primeiros anos, que são o marco inicial da construção da cronologia do presente capítulo. Salienta-se ainda que a seleção dos textos também teve critérios complementares, tais como a presença de uma definição - ainda que não precisa - de documentação em museus e sua ocorrência enquanto citação sobre o assunto. Definições mais recentes sobre o termo apresentadas pelo Comitê serão mostradas e discutidas no quarto capítulo, dedicado ao objeto empírico da pesquisa.

\subsubsection{CIDOC}

Como primeira delimitação de recorte temporal para o uso da expressão documentação em ambientes de museus é possível relacionar a introdução do mesmo na área de museus à criação do CIDOC, em 1950 (MARÍN TORRES, 2002). Stránsky (1994) também reconhece que a incorporação do termo pela área de museus ocorreu somente a partir da segunda metade do século $\mathrm{XX}$, em profunda conexão com a Documentação e a Ciência da Informação, como resultado da computadorização das atividades de formação de coleções. O autor ainda indica que o movimento de informatização dos registros das coleções foi uma prática iniciada 
na antiga União Soviética e nos países satélites, devido a uma campanha originada para documentar a construção do socialismo (STRÁNSKY, 1994). Nesse período inicial de atuação, os autores ligados ao CIDOC convencionaram o uso do termo documentation museographique - documentação museográfica - nas referências que publicaram.

Apesar de não ser possível precisar, a partir da bibliografia consultada, a origem exata do termo, ele encontra-se associado à produção da bibliotecária e documentalista francesa Yvonne Oddon, em sua publicação Elements de documentation museographique / Elements of museum documentation (1968). Na publicação, Oddon (1968, p. 2) explica que cabe aos museus "coletar e registrar informação apurada sobre toda a sua coleção independente de sua natureza: objetos de arte, material etnográfico ou científico, documentos históricos ou espécimes de história natural, etc." Esclarece, ainda na mesma página, que "tal documentação pode ser mantida em livros de registro, fichas, listas e arquivos, fotografias ou slides, filmes ou registros sonoros, documentos impressos e livros".

Para ela, a função primeira da documentação é assegurar e preservar a identidade da coleção para facilitar a administração do museu, seguida da apresentação, interpretação e estudo do acervo. A autora entende a operacionalização da documentação do acervo em diferentes serviços, o que a aproxima de uma tendência organizacional característica da Biblioteconomia (CERAVOLO, 2000). Os serviços compreenderiam o registro ou inventário; o catálogo; a fototeca ou eventualmente a filmoteca ou fonoteca; além da biblioteca. Para Olcina (1986), a obra de Oddon (1968) não possui precedentes na área.

Essa compreensão a respeito do papel da documentação em museus também era compartilhada por um dos parceiros de trabalho mais constantes de Yvonne Oddon, o museólogo, etnólogo francês e um dos fundadores do ICOM, Georges Henri Rivière. Para Rivière (1993), o termo documentação, por sua polissemia, seria o mais adequado para definir o conjunto de atividades de investigação realizadas pelo museu. Para ele, a documentação é componente do processo de musealização do objeto ou, em outras palavras, do processo de seleção e transformação de um objeto comum em museológico, com status documental, introduzido em um novo contexto relacional e interpretativo.

Nessa perspectiva, a documentação ganha a responsabilidade de organizar racionalmente a informação coletada sobre os objetos, que são "testemunhos 
objetivos e [...] fonte de um número infinito de interpretações e de análises" (RIVIĖRE, 1993, p. 228. Tradução da autora), por meio da elaboração de instrumentos documentais adequados ao seu registro, inventário e classificação. Sendo assim, a atividade documental colabora na produção de subsídios para retroalimentar a atividade de pesquisa e exposição (RIVIÈRE, 1993).

Ressalta-se que ambos os autores, Oddon e Rivière, expressam preocupação eminente com os esquemas classificatórios dos acervos. Particularmente, Riviére faz questão de reforçar a necessidade de classificar os acervos de modo a garantir o caráter científico da interpretação individualizada das peças dos acervos (RIVIÈRE, 1993). Yvonne Oddon (1970) também reforça a importância da classificação, mas consciente da vinculação expressa da criação de esquemas classificatórios com a atividade de pesquisa e a disciplina de base dos museus. Ela também apresenta distinção maior entre a atividade de documentação e de pesquisa, diferentemente de Riviére, que praticamente iguala as duas atividades e deixa dúvidas a respeito dos limites entre uma e outra.

O que aproxima as concepções de ambos é o significado subjacente ao uso do termo documentação museográfica. Isso ocorre porque a presença do adjetivo museográfica circunscreve a atividade de documentar ao âmbito da Museografia que, conforme visto no segundo capítulo, é entendida como a prática de museus (DESVALLÉES; MAIRESSE, 2009). Contudo, destaca-se que, pelo contexto dos autores, o entendimento dessa vertente aplicada é aquele que, tradicionalmente, separa mais acentuadamente a prática da teoria da Museologia, conforme destaca Loureiro (2008).

Apesar do uso recorrente do termo na produção de ambos, Oddon e Rivière não propõem diretamente uma definição do que é documentação museográfica. Contudo, no caso de Yvonne Oddon é possível inferir que a documentação é o conjunto de registros criados pelo museu para controlar a coleção. A partir desse controle, de caráter administrativo predominante, a documentação gerada - livros de registro, fichas etc. - pode subsidiar outras atividades da instituição, principalmente a pesquisa, por meio de procedimentos racionalizados. O que se percebe na estruturação proposta pela autora é a utilização de técnicas da Biblioteconomia e de instrumentos que eram comumente usados para análise e síntese de textos na organização física do acervo de museus. 
A ênfase na organização de instrumentos documentários - denominação dada por Oddon aos documentos criados para registrar os documentos 'primários', os objetos propriamente ditos, no dizer de Georges Henri Rivière - é uma evidência que permite entrever a influência do movimento da Documentação na produção da autora. A divisão entre documentos primários e secundários sugere uma influência particular de Suzanne Briet, que também classifica documentos como primários - os atribuídos como documentos - e secundários - criados para referenciar os primários -, conforme visto no segundo capítulo dessa dissertação.

É possível ressaltar que, diferentemente do caso da Documentação, conforme concebida por Briet (2006), na documentação museográfica predomina o aspecto do controle das coleções como definidor do seu significado. Além disso, é preciso destacar que a atividade documental possui uma proeminente faceta prática, sem maior detalhamento a respeito da sua relação intelectual com a atividade de pesquisa, por exemplo. Outro ponto que pode ser indicado para ilustrar a diferenciação é que a discussão em torno do uso da linguagem para representar os acervos, no caso das propostas de Oddon e Rivière, fica restrita à indicação da necessidade de sistemas classificatórios. Não há maior discussão sobre metodologias específicas para construção de tais sistemas, ou de padrões de descrição e indexação, que auxiliariam o tratamento da informação sobre os acervos.

Necessário fazer a ressalva de que nem Oddon ou Rivière possuíam como objetivo primeiro de suas produções sobre documentação esclarecer tais questões. Todavia, é possível manter a pertinência dos comentários acima se considerar que a documentação museográfica, enquanto ato de documentar, possui foco claro nos objetos de diferentes naturezas e suportes - o que por si só demandaria outras técnicas de leitura, análise e síntese para produção e tratamento de informação. Em outras palavras, por mais que os autores não desejassem traçar um perfil claro para a documentação museográfica ou mesmo defini-la em termos mais precisos, isso não implica que a atividade prescinde de tal detalhamento ou crítica.

\subsubsection{Reino Unido}

Outro termo a ser comentado é museum documentation - em uma tradução livre, documentação de museu -, apresentado como a tradução em inglês de 
documentation museographique no título da obra de Oddon (1968). Apesar de presente em uma publicação que conheceu ampla difusão na área de museus na Europa e fora dela, o termo teve seus próprios caminhos de utilização e significado no contexto britânico. Cumpre salientar que, no Reino Unido, as publicações lançadas sobre o assunto estiveram predominantemente ligadas à Associação Britânica de Museus, especificamente à Associação para Documentação de Museus - a MDA.

Uma série de publicações lançadas pela MDA marca o uso da expressão, a qual se acrescentou posteriormente, na década de 1980, a palavra system - sistema -, ficando o termo museum documentation system - sistema de documentação de museu. Em termos de definição, para Light, Robert e Stewart (1986), museum documentation system pode ser entendido como "referente aos procedimentos usados pelos museus para gerenciar informação relativa às suas coleções ou de relevância para suas funções curatoriais" (LIGHT; ROBERTS; STEWART, 1986, p. 1. Tradução da autora). A ideia de controle da coleção é destacada pelos mesmos autores, na mesma referência, ao afirmarem que:

\footnotetext{
Os objetivos principais de tal sistema incluem auxiliar o controle e uso das coleções e assegurar a preservação de informação sobre o patrimônio cultural e ambiental. [...] Seu escopo pode englobar a documentação de coleções físicas (objetos, itens bibliográficos, material de arquivo e material audiovisual) e conjuntos de informações como detalhes de conservação e fotografias documentais, pessoas, lugares, eventos e atividades. (LIGHT; ROBERTS; STEWART, 1986, p. 1. Tradução da autora).
}

Dois aspectos interessantes a serem ressaltados na definição apresentada pelos autores são: sua conexão com o princípio da Documentação, conforme a concepção de Briet, ao estabelecerem o processamento integrado de vários tipos de documentos para uma melhor recuperação da informação; e a preocupação expressa com o gerenciamento da informação - o que será alvo de publicações específicas da MDA na década de 1990. Porém, novamente como no caso de Oddon e Rivière, o foco na questão do controle da coleção é dominante, o que é uma característica distinta daquela da Documentação, que se preocupou em estabelecer o acesso às informações e aos documentos processados como um de seus princípios, desde Otlet. 


\subsubsection{Espanha}

Na Espanha, o termo documentação de museus também aparece associado à palavra sistema, como é possível observar no título da publicação de Porta, Montserrat e Morral (1982) Sistema de Documentación para Museos. Nesta publicação, há uma preocupação expressa com a criação de um plano de classificação de objetos. O plano se estrutura inicialmente com a separação entre os objetos que foram feitos pelo homem e aqueles que não foram feitos pelo homem, e passa a agrupá-los de acordo com sua função original, entendido como atributo comum a qualquer um dos itens. Não há notas de aplicação ou explicação das classes, e o plano é apresentado na publicação como uma solução que, por inferência, compreende-se que deva ser adotada por todos os museus que seguirem a proposta do Departamento de Cultura da Catalunha.

O significado central atribuído à ideia de sistema de documentación para museos - sistema de documentação para museus - é de que a documentação se organiza como conjunto de atividades, em que todas as etapas de trabalho - registro de entrada, aquisição, numeração, marcação, incorporação ao inventário geral, alocação em reserva técnica, catalogação, empréstimo e exposição - são interligadas. A interligação pressupõe uma série de procedimentos interconectados para gerenciamento das coleções. O principal objetivo do sistema é gerenciar a circulação física das peças dentro dos museus, desde o momento de sua entrada até sua localização nas áreas de guarda ou nas áreas expositivas. Em outras palavras, para auxiliar o controle da coleção - o que é o objetivo primeiro da publicação catalã.

Tal como no caso da expressão inglesa museum documentation system, é perceptível a preponderância da associação de aspecto prático à ideia de documentar acervos em museus, sem maior aprofundamento teórico. Uma diferença entre os dois contextos é que no caso das publicações da MDA/Reino Unido, a concepção da ideia de sistema de documentação admite uma preocupação maior com as ações de organização da informação - relacionando eventos, datas, pessoas e lugares, às peças do acervo - e não somente com o estabelecimento de procedimentos de organização física da coleção, como é o caso da obra de Porta, Montserrat e Morral (1982). Novamente, é válido dizer que as publicações em questão possuíam objetivos distintos, mas do mesmo modo é pertinente salientar 
também que a ocorrência dos termos permite a comparação entre seus usos e respectivos conceitos.

Porém, a expressão sistema de documentación para museos não teve uso uniforme na Espanha. O arqueólogo e investigador científico do Conselho Superior de Investigações Científicas do Ministério da Ciência e Tecnologia da Espanha, Luis Caballero Zoreda, adota o termo documentación museológica - documentação museológica - em seu artigo intitulado Documentación Museológica, de 1988. O autor define a expressão como processo de tratamento dos dados existentes nos museus, sejam eles extraídos dos objetos ou de outras fontes de informação, e cita a publicação de Porta, Montserrat e Morral (1982) como uma de suas referências para o artigo.

No texto, Luis Caballero Zoreda se preocupa com a indicação das bases jurídicas que devem orientar os museus espanhóis sobre a divisão das etapas e procedimentos de trabalho. Além disso, se detém sobre as características dos instrumentos documentários - contratos de doação, inventários, fichas de registro e catálogos - e o tipo de informação que deve constar em cada um. Nesse sentido, embora não utilize a palavra sistema, sua descrição do trabalho documental se aproxima da concepção de Porta, Montserrat e Morral (1982).

Dez anos depois é lançado o Manual de Museología (1998), outra obra de referência em linha espanhola, com autoria de Francisca Hernández Hernández, arqueóloga e professora titular do Departamento de Pré-História da Universidade Complutense de Madrid. Nessa publicação, a autora utiliza outro termo, documentación de las colecciones - documentação das coleções. Para ela, a documentação deve "reunir e registrar informações exatas sobre todos os fundos existentes no mesmo" (HERNÁNDEZ HERNÁNDEZ, 1998, p. 136. Tradução da autora), tendo como foco a recuperação de dados sobre os objetos. Ela também cita como base para tal entendimento a publicação de Porta, Montserrat e Morral (1982).

$\mathrm{Na}$ bibliografia produzida naquele país, a ideia de fundo se assemelha à de conjunto, agrupamento de documentos. Nesse sentido, os fundos podem ser museográficos, documentais ou bibliográficos. Segundo Carretero Pérez et al. (1998), os fundos museográficos são compostos por séries objetuais, geralmente tridimensionais, cuja conservação, catalogação, restauração e exibição ordenada constituem o cerne de um museu. No caso dos fundos documentais, são compostos por séries documentais com diferentes suportes de escrita, imagem e som. Os 
documentos são únicos e não podem ser cópias. Podem ser entendidos como partes dos fundos museográficos, mas de um tipo especial, pois não possuem finalidade expositiva à primeira vista, servindo mais para fins investigativos. No caso dos fundos bibliográficos, eles são formados por séries documentais em diferentes suportes, cuja característica básica é não ser de objetos únicos, mas com edição sistemática. São considerados elementos de apoio à investigação, exibição e difusão dos fundos museográficos. Apesar da delimitação indicada, os próprios autores admitem que nem sempre ela é facilmente alcançada dentro de um museu.

Para combater o empirismo e a descontinuidade do trabalho de registro de informações sobre os objetos que marcam a documentação, Hernández Hernández (1998) sugere a organização dos procedimentos em sistema, que deve ter como características fundamentais a fidelidade, flexibilidade e economia. Mesmo adotando a expressão documentação de coleções, a autora se reporta ao artigo de Caballero Zoreda (1988) para indicar a pertinência na incorporação de tais conceitos na concepção e utilização de um sistema por profissionais e usuários do museu.

Maria Teresa Marín Torres, diplomada em Biblioteconomia e Documentação, doutora em História da Arte e professora do Departamento de História da Arte da Universidade de Murcia, Espanha, utiliza, do mesmo modo que Caballero Zoreda (1988), o termo documentación museológica - documentação museológica - em outra obra de referência. A obra intitula-se História de la documentación museológica: la gestión de la memoria artística, publicada em 2002. Para a autora, a documentação museológica é uma parte disciplinar da ciência museológica que se encarrega do estudo da teoria, história, técnicas e procedimentos utilizados pelos museus na hora de gerenciar e dar um sentido informativo e científico às coleções. O objeto de estudo seria a documentação museográfica propriamente dita - os registros documentais - catálogos, inventários, guias, etc.

Para a autora, falar em documentação museológica e documentação museográfica faz sentido devido à distinção entre a Museologia, que se dedica ao estudo dos fenômenos museísticos e que possui proximidade inegável teórica e metodológica com a área de cultura material, e a Museografia, área que realiza estudos com orientação mais prática. Indo além, ela ainda reforça que o termo documentação museológica tende a ser substituída, cada vez mais, pela expressão gestão da informação. 
Como já comprovado, a gestão da informação leva em consideração os serviços de informação que funcionam em uma organização para a própria organização como sistema informativo, dado que toda organização recebe, processa e emite dados e informação, como ocorre com os museus. [...] No âmbito estadunidense, se tem compreendido a documentação como uma faceta da 'gestão das coleções' desde a década de setenta. Também triunfou este termo (collection management) e conceito no Reino Unido, entendendo que se baseia em duas operações básicas: a conservação e a documentação dos objetos e da informação associada a eles. [...] Portanto, a tendência no âmbito anglo-saxão é a progressiva consolidação do termo gestão da informação em vez de documentação, mas compreendida dentro dessa parcela vertebral do museu que é a gestão das coleções. (MARÍN TORRES, 2002, p. 303-304. Tradução da autora).

Nesse trecho, a autora reforça seu entendimento favorável à concepção da documentação, não somente como atividade relativa ao controle das coleções, mas que se estende à produção de informações e sobre o acervo. Entre os autores apresentados até o momento, é a primeira com uma proposta direta e expressa de definição sobre o que é documentação, e que possui interesse em identificar suas diferentes nuances enquanto conceito. Sua explicação também dá a entender que a perspectiva de países anglo-saxões, como os do Reino Unido e Estados Unidos, tende a ser predominante na contemporaneidade. Tal direcionamento permite igualmente a compreensão de que diversas possibilidades de modificação se apresentam para o fazer documentário nos museus.

A primeira delas, e talvez a mais significativa que se pode entrever, é a extrapolação, ao menos teórica, de uma abordagem tradicional sobre a documentação, que a insere no âmbito da prática de museus como restrita apenas à identificação e localização física das peças. Já na abordagem baseada no conceito de gestão de coleções, a documentação se consolida como uma ação transversal, vertebral para o museu. Ela se torna uma atividade que se preocupa mais com a organização dos conteúdos gerados em torno da coleção, ou, em outras palavras, a documentação passa a ser a base para um processo maior e complexo - a gestão das coleções. Isso se dá porque a lógica que operacionaliza a gestão não está focada somente na questão do controle e segurança física das coleções, mas também na produção, integração e difusão de informação sobre elas.

Posição semelhante é compartilhada por Andrés Gutiérrez Usillos, doutor em História pela Universidade Complutense de Madrid, que atuou durante anos como chefe da área de Registro e Documentação do Museu Nacional do Prado, e posteriormente exerceu o cargo de subdiretor geral adjunto dos Museus Estatais do 
Ministério da Cultura da Espanha. Atualmente, ocupa o cargo de coordenador de projetos no Museu da América, em Madrid. O autor publicou o livro Museología y documentación: criterios para la definición de un proyecto de documentación en museos, em 2010, que também já se estabeleceu como outra referência sobre o assunto.

O autor adota a expressão documentación en museos - documentação em museus -, e a define como um processo que compreende as funções de registro, inventário e controle dos movimentos dos objetos e sua catalogação, entendida por ele como documentação científica (GUTIÉRREZ USILLOS, 2010). Ele salienta ainda que a documentação é uma primeira fase de um processo de tratamento da informação pelos museus, que inclui ainda as fases de recolhimento e análise de documentos, bem como de recuperação e, por último, de difusão da informação.

Para ele, a documentação deve realizar uma 'arqueologia do presente', dedicando-se a entender não apenas o modo como os objetos foram feitos, mas a compreender $\mathrm{O}$ artefato nas suas relações com os seres humanos em seus contextos primário e institucional (GUTIÉRREZ USILLOS, 2010). Desse modo, ele se aproxima da tendência indicada por Marín Torres (2002) de propor a gestão da informação como conceito maior e mais amplo para a documentação nos museus.

\subsubsection{Estados Unidos}

Segundo Marín Torres (2002), o termo que se consagrou ao longo dos anos nos Estados Unidos para designar as ações de documentação das coleções de museus foi registration - registro - e, posteriormente, a expressão collection management - gestão de coleção. Um exemplo disso é o manual Museum Registration Methods, cuja primeira versão foi lançada em 1959, pela Associação Americana de Museus. O mesmo manual recebe atualizações periódicas e atualmente encontra-se em quinta edição, mantendo o mesmo título.

Essa publicação traz, desde sua primeira edição, a indicação de melhores práticas e procedimentos para realização de procedimentos de controle da coleção: o que deve ser feito na entrada de cada um dos objetos, métodos que devem ser adotados para solucionar situações como a existência de propriedades abandonadas nos museus, ou peças que foram encontradas na coleção sem informação sobre sua entrada. 
No contexto da bibliografia estadunidense, o registro é uma ação preliminar no cuidado com as coleções e distingue-se da atividade de documentação, entendida como sendo de caráter eminentemente curatorial ou científico, como explica Reibel,

\begin{abstract}
Nos Estados Unidos é normal separar o registro da documentação. A prática usual é considerar que [o termo] registro se aplica a todos os documentos gerados no processo de aquisição, incorporação, e catalogação e que documentação se aplica à pesquisa desenvolvida sobre - objeto e a coleção. [...] Algumas pessoas na área de museus aplicam o termo 'documentação' para todos os documentos desenvolvidos durante a incorporação de um objeto a coleção. Eles incluem expressamente aqueles que eu separo como documentos de 'registro'. Este uso é mais recorrente no Reino Unido do que nos Estados Unidos, embora o termo documentação aplicado como registro também seja comum por aqui. Eu separo os dois termos neste livro em parte para seguir a prática vigente nos Estados Unidos, e em parte para evitar confusão. Para fins deste livro 'documentação' é parte do processo de registro, não o processo em si! (REIBEL, 2008, p. 75. Tradução da autora).
\end{abstract}

Nesse caso, Reibel (2008) denomina de registro os tipos de documentos que, segundo os autores europeus apresentados até o momento, são compreendidos como sinônimos da documentação. No caso estadunidense, o termo registro também designa o processo maior de identificação das peças, sendo que a documentação, propriamente dita, se restringe a apenas parte desse processo e gera somente alguns tipos documentais associados à atividade de pesquisa. Cumpre salientar, todavia, que em termos de terminologia empregada, aqui também há o uso de um mesmo termo para designar os documentos e o processo em si, tal como ocorre com os casos europeus apresentados até o momento. O que vale destacar é que nos Estados Unidos o termo documentação é associado diretamente com a atividade - e conceito - que faz parte da pesquisa científica e curatorial sobre as coleções. Infere-se que o termo encerre nesse uso uma ideia de atividade destinada a registrar a produção de conhecimento e interpretação sobre o acervo, não possuindo, aqui, o aspecto predominante de controle que é identificado nas abordagens europeias sobre o termo documentação discutidas até o momento.

\title{
3.2.5. Brasil
}

No Brasil, é possível citar a existência da mesma variação em torno da palavra documentação, no contexto dos museus. Para realizar o mesmo percurso 
cronológico apresentado para os autores europeus e estadunidenses, é possível referenciar duas publicações nacionais da década de 1950. A primeira delas é de autoria de Gustavo Barroso, mentor do Curso em Museus do Museu Histórico Nacional e responsável pela formação dos primeiros profissionais de museus no Brasil. Em sua publicação Introdução à Técnica de Museus (1951), que durante muito tempo foi o livro de base para a formação dos profissionais que frequentaram - curso supracitado (SIQUEIRA, 2009), o autor estabelece as atividades de catalogação como componentes da parte geral da técnica de museus, compreendendo-a como "o conjunto de regras, princípios, observações e conhecimentos indispensáveis à organização e funcionamento dum museu." (BARROSO, 1951, p. 7).

A catalogação compreende: numeração, etiquetagem, catálogo enumerativo, catálogo descritivo, catálogo comentado e fichário (BARROSO, 1951). O foco reside no estabelecimento dos tipos de documentos, mais do que na explicação do fluxo de informação entre eles. O registro de informações é visto como uma atividade essencialmente ligada à responsabilidade do museu em ter tudo sob seu controle.

Florisvaldo dos Santos Trigueiros (1958), museólogo baiano formado pelo Curso de Museus em 1951 (SIQUEIRA, 2009), em seu livro Museu e Educação apresenta as diferentes funções de um museu, com destaque para a documentação. Para ele, o museu seria um dos órgãos mais antigos de documentação, sendo por isso muito importante para a educação do povo. De forma diversa de seu professor Gustavo Barroso, o autor cita expressamente Paul Otlet como fundador da sistematização da Documentação e suas categorias possíveis de documentos, incluindo os objetos de museu.

Trigueiros utiliza o termo no sentido disciplinar, como Documentação, e não a restringe apenas à técnica de catalogação. Apresenta a definição da Documentação como um "processo pelo qual se reúnem, catalogam e classificam todos os documentos informativos das atividades humanas, promovendo a sua divulgação pelos meios modernos de publicidade, a fim de dar aos estudiosos os elementos necessários a seu trabalho" (TRIGUEIROS, 1958, p. 26).

O autor também prevê o estabelecimento de serviços de Documentação e a utilização de instrumentos como catálogos, boletins, anuários, programas de rádio, filmes documentários, fotografias e de técnicas variadas, que poderiam auxiliar os profissionais a tratar um documento. Seu discurso é orientado pelo reforço constante 
da ideia principal da disciplina Documentação, conforme sua concepção europeia: prover acesso para o que denomina de aprimoramento cultural das pessoas.

Quase três décadas depois, em 1986, Fernanda de Camargo-Moro, museóloga, historiadora, com doutorado e pós-doutorado na área de Arqueologia, presidente do Comitê Brasileiro do ICOM entre 1976-1987, lança seu livro Museu: aquisição/documentação. O livro se constitui até os dias de hoje como uma das poucas obras totalmente dedicadas ao assunto produzidas no Brasil. Sua vinculação com a produção de Yvonne Oddon é inegável, tendo em vista as várias referências diretas feitas à documentalista francesa ao longo do texto. Camargo-Moro adota o termo documentação, ao qual ela define como:

1) Processo de organização dos diversos elementos de identificação do acervo; 2) Conjunto de conhecimentos e técnicas que tem por fim a pesquisa, reunião, descrição, produção e utilização dos documentos sobre as coleções. (CAMARGO-MORO, 1986, p. 238)

Ou seja, há a compreensão de que a documentação é tanto o processo de coleta e produção de informação, quanto o resultado desta ação, que é o registro de toda e qualquer informação sobre o acervo.

Ao longo dos capítulos, Camargo-Moro (1986) apresenta outras evidências da vinculação com as propostas de Oddon sobre documentação museográfica - como a divisão do trabalho documental em várias etapas e uma preocupação expressa com os tipos de documentos que devem ser utilizados e que tipo de informação deve ser coletado. Ao se dedicar a uma etapa que designa como "documentação para aprofundamento da decodificação dos acervos", a autora dá orientações sobre o que deve ser considerado na construção de uma ficha classificatória, por exemplo. Nesse caso, cita a Ficha Oddon 1 ou Oddon 1 - polivante, elaborada pela documentalista francesa durante os anos de 1971 e 1973 no Centro de Documentação UNESCO-ICOM, para ser aplicada em qualquer tipo de museu. Ela ganhou o nome de polivalente justamente por permitir o acréscimo de informações à sua estrutura original, e segundo Camargo-Moro (1986, p. 86), tal ficha era usada de forma extensa.

O livro ainda traz como anexos exemplos de aplicação da ficha e um guia que fornece orientações para catalogação e análise das coleções dos museus mistos, escrito por Yvonne Oddon. Camargo-Moro (1986) também apresenta os pormenores 
de tipos de índices que devem ser construídos, bem como destaca a importância da adoção do que denomina de convenções, tais como glossários, nomenclaturas e outros tipos de vocabulários controlados para documentação do acervo. Válido ressaltar que, no final do livro, ao falar sobre os elementos auxiliares de documentação, como catálogos, etiquetas expositivas, periódicos, etc., a autora ressalta a dimensão comunicativa da documentação em museus. Tal enfoque até então não havia sido ressaltado pelos outros autores brasileiros citados até o momento, muito embora, seja necessário reconhecer que tal pressuposto foi abordado por Oddon e Rivière, apesar de não desenvolvido.

Para a documentalista Helena Dodd Ferrez, que durante muitos anos atuou na área de museus e na Fundação Nacional de Artes - FUNARTE - à frente da estruturação das Redes de Bibliotecas de Arte - REDARTE -, o termo adotado é documentação museológica. Para ela, a documentação museológica é o conjunto de informações sobre cada um dos itens que compõem as coleções, e, por consequência, é também o processo de preservação dos mesmos através da sua representação por meio da palavra e da imagem (FERREZ, 1991). Em outras palavras, a documentação é preservação e representação, atuando por meio da linguagem para dar permanência e ofertar significados. Ao mesmo tempo, a autora entende a documentação como um sistema de recuperação da informação capaz de transformar as coleções em fontes de pesquisa científica, ou em fontes de informação e produção de conhecimento. Com base na ideia de sistema, é possível compreender que o trabalho de tratamento da informação é direcionado por um conjunto interligado de etapas, tal como já visto em outros autores que adotam a mesma terminologia. Ela também sinaliza a equivalência entre os termos documentação museológica e documentação de acervos museológicos.

A autora salienta que os objetos possuem dois tipos de informação: as intrínsecas, relativas aos seus aspectos físicos; e as extrínsecas, relativas a aspectos contextuais e documentais do objeto, que devem ser investigados a partir dele. Logo, a autora apresenta um modelo tridimensional de abordagem do objeto, desenvolvido pelo museólogo holandês Peter Van Mensch (1989) e que é dividido em: propriedades físicas - composição material, construção técnica, morfologia; função e significado - significado principal e secundário; e história - gênese, uso, deterioração, conservação e restauração. A esta configuração, Ferrez (1991) 
denomina estrutura informativa do objeto de museu, que deve ser contemplada pelas ações previstas no sistema de documentação.

Segundo Rosana Andrade Dias do Nascimento (1994), diplomada em Museologia com doutorado em História, professora do Departamento de Museologia da UFBA de 1989 a 2009, do Departamento de Expressões Gráficas da UFSC de 2009 até atualmente, e colaboradora da pós graduação em Museologia da Universidade Lusófona de Humanidades e Tecnologia, a ideia de documentação museológica se estende para além da concepção que a aborda, como toda forma de informação referente ao acervo de um museu e, por conseguinte, sua representação e preservação por meio da palavra e da imagem.

Ela faz uma crítica a essa abordagem, devido ao fato de estabelecer que toda e qualquer informação sobre o objeto seja registrada em instrumentos específicos, auxiliados por perguntas tradicionais para a identificação do objeto - Quem é você? Como você se chama? Quem o fez? De que você é feito? Etc. -, que se restringem ao que ele apresenta materialmente e burocratizam o processo documental. Desse modo, a ação documental acaba por entender o objeto isoladamente do restante do acervo, se voltando para seu passado e não mais para sua inserção em um novo contexto, que é o do museu. Em outras palavras, o objeto é visto como um produto encerrado em si mesmo e não como um constante processo de conhecimento construído pelo museu.

A autora chama a atenção ainda ao fato de que a documentação deve possuir uma finalidade associada à função social e comunicativa do museu, reforçando a percepção de que a instituição deve ter um papel diferenciado na sociedade ao seu redor. Desse modo, todas as suas ações devem ser direcionadas para tanto, de modo a consolidar uma forma de atuação que seja condizente com essa perspectiva pedagógica sobre a atuação das instituições museológicas - o que, como visto no segundo capítulo, reflete o movimento de discussões e críticas realizadas a partir da década de 1970 ao modelo tradicional de museu. Todavia, Nascimento (1994) salienta também que, para alcançar esse fim, ainda é necessário o amadurecimento de uma proposta teórico-metodológica que embase 0 ato de documentar, engajando-o a uma concepção de educação e de museu. Ela propõe que a historicidade seja a metodologia de base para a documentação, de modo a explicitar as teias e relações que enredam o objeto dentro de um contexto, rompendo com uma perspectiva tecnicista sobre o mesmo. 
Suely Ceravolo (1998), museóloga e diplomada em história, com doutorado em Ciência da Informação na ECA-USP e professora do Departamento de Museologia da UFBA (2002-atual), introduz no cenário brasileiro uma discussão sobre a pertinência do uso da expressão documentação museológica. Para ela, não há sentido falar em documentação museológica, pois em seu entendimento a Museologia é "algo além do que a simples soma das partes das atividades de um museu" (CERAVOLO, 1998, p. 28). Segundo a autora, só faria sentido utilizar a expressão documentação museológica se

\footnotetext{
[se] empregar (ou aceitar) o domínio Museologia com foco no fato museal e não somente aos museus. Ou seja, ao se advogar a idéia de que os museus são parte de um universo muito mais amplo que ultrapassa a instituição 'museu'. (CERAVOLO, 2012, s/p).
}

Em outras palavras, para a autora, o uso do termo documentação museológica, tal como se dá hoje, a insere como sinônimo de atividade exclusiva de museu. Todavia, o adjetivo 'museológica' qualifica a documentação como algo que pertence ou é exclusivo à Museologia - e esta disciplina, como já abordado no segundo capítulo, se estende para além do universo restrito dos museus e de suas atividades práticas. Assim, infere-se que 0 uso da expressão documentação museológica contém um paradoxo, tendo em vista os termos nos quais a mesma é empregada atualmente.

Por outro lado, a mesma autora evidencia que o emprego do termo documentação museológica seria pertinente se seu significado se referisse, dentro do domínio da Museologia, às ações documentais imbricadas no processo de musealização de bens culturais. Incluir-se-iam aqui aquelas também realizadas pelos museus, mas não restrita a eles, como hoje ocorre. Ou seja, para ser 'museológica', a documentação deveria ser concebida dentro do sistema conceitual ou do corpus da Museologia, sendo-Ihe própria, particular. Cumpre ressaltar que a crítica realizada pela autora ao uso atual da expressão documentação museológica é partilhada por este trabalho, do mesmo modo que sua indicação de que o termo só tem pertinência mediante uma revisão do seu significado no âmbito do corpus da Museologia - o que corrobora a necessidade de aproximações e comparações com outras áreas, como a Documentação e a Ciência da Informação. 
Desse modo, Ceravolo adota a expressão documentação de museus, pois o uso do adjunto adnominal "de" traz o "sentido de alvo da ação nessa instituição não em outra, pois particular a ela" (CERAVOLO, 1998, p. 27). Desse modo, a autora sinaliza que circunscreve sua reflexão apenas às ações documentais ocorridas no âmbito da musealização que os museus promovem, com a intenção de indicar suas diferentes nuances, detalhadas a seguir.

$\mathrm{Na}$ opinião de Ceravolo (1998), para discutir documentação de museus é preciso reconhecer duas premissas principais: que a atividade de documentar, embora parta de objetos materiais, formula operações de representação baseadas na linguagem; e, além disso, é preciso reconhecer como pressuposto básico que a concepção da documentação como um sistema, orientado ao controle do acervo, não estabelece por si só uma metodologia de tratamento da informação. Portanto, conceber a documentação como um sistema não é suficiente para abarcar toda a complexidade envolvida nas operações de processamento documentário de acervos museológicos.

A autora propõe que a documentação de museus seja concebida como a reunião de dois conjuntos de atividades: o que congrega operações sobre o suporte físico das coleções - controle de localização, entrada e saída do museu, etc., ou o sistema de documentação de museus - e o conjunto de operações sobre o conteúdo das coleções - criação de padrões de indexação, classificação, etc., ou o sistema de informação documentária de museus. Ela destaca que no caso dos objetos resulta quase impossível, por vezes, separar o que é forma do que é conteúdo, pois ambas as dimensões estão diretamente imbricadas. Desse modo, o processo da documentação conseguiria subsidiar as atividades curatoriais, técnicas e administrativas de forma condizente com a demanda existente nas instituições.

Para propor uma abordagem integral das diferentes dimensões informativas que podem ser construídas em torno e sobre o acervo, ela propõe, em coautoria com a linguista e professora da Escola de Comunicações e Artes da USP, Maria de Fátima Moreira Gonçalves Tálamo, que o objeto seja tratado a partir do conceito de matriz da informação (CERAVOLO; TÁLAMO, 2007). Segundo as autoras, a aplicação do conceito permite que todas as informações sobre os objetos sejam as relativas ao plano material - suporte -, e ao plano associado ao conteúdo sejam tratadas de forma conjunta e atributiva. Para elas, somente com a associação dos dois planos é possível realizar a análise do objeto. 
Ceravolo (1998) destaca ainda que a atividade de documentação, embora se relacione com a atividade de pesquisa, com ela não se confunde. A documentação de museus opera sobre as informações das coleções a fim de torná-las disponíveis para recuperação. Desse modo, a documentação organiza uma estrutura que provê acesso ao estoque de informação de um acervo. A pesquisa, por sua vez, promove o desenvolvimento da interpretação sobre os objetos, gerando o estoque de conhecimento e não se preocupando imediatamente com questões relativas às formas como ele será organizado, nem com o acesso.

Lourdes Rego Novaes é outra museóloga brasileira que propõe uma definição para documentação. Novaes foi presidente do ICOM-BR entre 1976 e 1987, e autora de trabalhos sobre a história do ICOM no Brasil em colaboração com Fernanda de Camargo-Moro (BRUNO, 2010). Desse modo, é possível circunscrever sua contribuição no âmbito de autores nacionais que possuem influência na discussão internacional realizada pelo ICOM, seu Centro de Documentação e os Comitês, dentre eles o CIDOC.

Logo, é concebível afirmar a existência da conexão do pensamento de Oddon na escolha feita por Novaes ao usar o termo documentação museográfica em um artigo seu publicado em 2000. Para ela, a documentação museográfica é "o processo de coletar, organizar, guardar, localizar e dispor documentos, ou a informação contida neles, sobre os objetos das coleções museológicas" (NOVAES, 2000, p. 51). Apesar da terminologia da autora remeter à ideia da documentação como processo/resultado da ação tal como presente em Oddon (1968), a descrição das atividades da documentação feita por Novaes a aproxima da concepção apresentada por Helena Dodd Ferrez (1991).

Nota-se também uma influência direta da ideia de ciclo documentário, ou ciclo informacional, presente na Ciência da Informação. Segundo Dobedei (2002), o ciclo documentário, ou ciclo de informação, é um modelo de caráter sistêmico que representa a transferência de informação, reduzindo a realidade de representação do conhecimento em seis etapas: produção, registro, aquisição, organização, disseminação e assimilação. Todavia, o texto não avança no detalhamento das operações quando aplicadas aos acervos museológicos, tendo em vista se tratar de um texto que não foi necessariamente produzido para ser processado no contexto de um ciclo documentário. É possível ressaltar ainda a ausência do aspecto da assimilação na definição de documentação apresentada por Novaes, e que é uma 
das bases de um ciclo informacional - o que permite a compreensão de que a documentação museográfica não adentra no universo do contexto de uso ou de apropriação da informação, mas somente na sua produção e organização.

Para Marilúcia Bottallo, museóloga e diplomada em História, com doutorado em Ciência da Informação na ECA-USP, e que trabalhou durante anos na Pinacoteca do Estado e depois no Museu de Arqueologia e Etnologia da USP, o termo adotado é documentação de acervos. Para ela, o objetivo da documentação de acervos é a realização de coleta, triagem, organização, controle, armazenagem, recuperação e divulgação das informações para seu uso como base para as ações curatoriais e exposições. Também aqui é admissível entrever a ideia de ciclo documentário ou informacional como proposta de base para a documentação em museus (BOTTALLO, 2000). A diferença em relação à abordagem de Novaes reside na consideração da faceta de divulgação da informação e na indicação de um local para sua apropriação, ou seja, as ações curatoriais e exposições.

Para Bottallo, o esforço de processamento da informação operado pela documentação "se constitui como imagem, portanto, como forma de representação do mundo" (BOTTALLO, 2000, s/p), sendo carregada de ideologias em seus métodos que influenciam o modo como o acervo é visto e interpretado. A autora salienta que a documentação de acervos não substitui experiências diretas junto aos objetos, mas deve contribuir para que o maior número de informações seja recolhido e processado, a fim de garantir os subsídios da compreensão entre público e acervo. A mesma autora também adota, em outros textos, as expressões documentação de gestão museológica (BOTTALLO, 1996) e documentação museológica (BOTTALLO, 2010).

Para José Mauro Matheus Loureiro, museólogo, doutor em Ciência da Informação e professor do Departamento de Estudos e Processos Museológicos da Universidade Federal do Rio de Janeiro/Uni-RIO desde 1999, o termo adotado é documentação museológica. O autor a define como a instância, dentro da Museologia, responsável por organizar:

domínios de informação instituindo processos e construindo instrumentos essenciais nos quais os diversos produtores e usuários de informação possam estabelecer princípios racionais de preservação, gestão e acesso a essas informações. A fragmentação dos saberes inerentes à modernidade ocidental e a heterogeneidade das produções concretas e simbólicas dos diferentes grupos sociais são estrategicamente ordenadas e inter- 
relacionadas, de forma a atender às demandas dos diferenciados agentes sociais e institucionais em suas mais variadas necessidades. [...] Documentar é, sobretudo no âmbito museológico, integrar em conjuntos significativos as tradições, diferenças e dispersões que caracterizam as ciências, saberes e discursos contemporâneos em benefício dos mais diferentes grupos sociais. (LOUREIRO, 2008, p. 28-30).

Desse modo, Loureiro (2008) é um autor que adota a expressão com maior número de ocorrências no Brasil, mas que chama a atenção para o aspecto comunicacional da documentação. Para ele, o ato de documentar é um ato de instituir processos que ofertam informações que fazem sentido para diferentes usuários - o que insere a documentação no âmbito da problemática da relação entre os diferentes grupos sociais interessados e o seu patrimônio preservado. Compreende-se, portanto, que Loureiro (2008) reforça que toda e qualquer atividade documental deve ser executada a partir de uma intenção de tecer relações, de ressignificar o patrimônio musealizado. Cabe à documentação reunir aquilo que, por exemplo, a "fragmentação dos saberes inerentes à modernidade ocidental" (LOUREIRO, 2008, p. 29) dispersou - o que permite a compreensão de que a documentação tem, assim, o potencial de se consolidar como uma atividade transversal e inerente a um complexo de processos de musealização - do qual o museu faz parte.

Por último, vale mencionar a reflexão de Johanna Smit, diplomada em Biblioteconomia e Documentação com doutorado em Análise do Discurso, e professora do Departamento de Biblioteconomia e Documentação da ECA/USP desde 1981, sobre as ações documentais dos museus. A autora aborda a questão da seguinte forma:

O acervo museológico, propriamente dito, não será aqui discutido, mas enfocaremos dois grupos de documentos gerados nesse contexto:

- a documentação do acervo, reunindo informação sobre a origem dos objetos, como estes chegaram ao museu, sua descrição (materiais, métodos, inscrições etc), pesquisas feitas para sua contextualização, localização física, questões patrimoniais ou de direitos autorais, intervenções que se fizeram necessárias, ações de preservação etc [...]

- a documentação do uso feito do acervo - a montagem de uma exposição, o empréstimo de uma obra pertencente a outro museu, a pesquisa sobre determinado artista para selecionar as obras mais representativas para terminada exposição, etc geram documentos, igualmente associados às atividades finalísticas do museu, mas que 
não devem ser confundidas com a documentação do próprio acervo. (SMIT, 2010, p. 36-37)

A partir dessas definições, a autora ressalta a necessidade não somente de se pensar quais são os tipos de documentos mais adequados para cada ação, mas também de analisar a informação que é produzida sobre eles e o modo como é possível potencializar o acesso a esses dados. Para ela, é de suma importância que os conjuntos de documentos sejam organizados de modo orgânico, e não de forma autônoma e dispersa, impossibilitando a recuperação da informação por diferentes usuários - o que faz parte da missão de um museu. Desse modo, apesar da autora não adentrar no debate sobre a definição de documentação em museus, ela chama atenção para a necessidade de se operar sobre os registros documentais gerados pelos museus com outra lógica que não a sedimentada pelas tradições profissionais que, muitas vezes, isolam os acervos.

\subsection{Análise das variações}

É válido ressaltar que o levantamento apresentado neste capítulo é considerado apenas como uma contribuição inicial à discussão interdisciplinar sobre os significados atribuídos a ideia de se fazer documentação em museus. Sendo assim, um primeiro aspecto a ser ressaltado a partir do inventário é que seu uso pelos diferentes autores é diverso, reforçando o entendimento de que se trata de um termo polissêmico. Nessas apropriações, é igualmente válido destacar que o termo se encontra já profundamente enraizado na literatura da área de museus, particularmente a produzida no âmbito da Museologia. A fim de retomar os contextos abordados neste capítulo, propõe-se o seguinte quadro sintético a respeito das variações em torno do termo documentação aplicado ao universo dos museus: 
Quadro 1 - Ocorrências do termo documentação na literatura da Museologia e da área de museus na Europa, Estados Unidos e Brasil, entre a década de 1950 a 2000.

\begin{tabular}{|c|c|c|}
\hline CIDOC e Europa- Reino Unido e Espanha & Estados Unidos & Brasil \\
\hline $\begin{aligned} \text { Anos } 1960 / 1970 \\
\rightarrow \text { Documentação museográfica (Yvonne Oddon } \\
\\
\quad-\text { UNESCO/ICOM) } \\
\rightarrow \text { Museum documentation }\end{aligned}$ & $\begin{aligned} \text { Anos } & 1900 \text { - anos } 2000 \\
& \rightarrow \text { Registration/registrar } \\
& \rightarrow \text { Collection management } \\
& \rightarrow \text { Information management }\end{aligned}$ & $\begin{array}{l}\text { Anos } 1950 \\
\quad \rightarrow \text { Documentação } \\
\quad \rightarrow \text { Catalogação }\end{array}$ \\
\hline $\begin{array}{l}\text { Anos1980/1990 } \\
\quad \rightarrow \text { Museum documentation system } \\
\quad \rightarrow \text { Sistema de documentación museológica } \\
\quad \rightarrow \text { Documentación museológica }\end{array}$ & & $\begin{array}{l}\text { Anos1980/1990 } \\
\quad \rightarrow \text { Documentação museográfica } \\
\rightarrow \text { Documentação museológica } \\
\rightarrow \text { Documentação em museus } \\
\rightarrow \text { Documentação de gestão museológica } \\
\rightarrow \text { Documentação de acervos } \\
\rightarrow \text { Documentação }\end{array}$ \\
\hline $\begin{aligned} & \text { Anos } 2000 \\
& \rightarrow \text { Collection management/gestión de } \\
& \text { colecciones } \\
& \rightarrow \text { Information management/gestión de la } \\
& \text { información }\end{aligned}$ & & $\begin{array}{l}\text { Anos } 2000 \\
\quad \rightarrow \text { Documentação museológica }\end{array}$ \\
\hline
\end{tabular}

Fonte: Juliana Monteiro, 2013. 
A partir do Quadro 1, acima, é possível compreender que o uso expandido do termo documentação na área de museus se deu predominantemente a partir do contexto europeu, com protagonismo da ação de uma iniciativa internacional - o CIDOC. A literatura consultada permite dizer que a ideia de documentação nos museus, a partir da década de 1950 até meados da década de 1970, era sinônima de processo de organização de/ato de documentar um conjunto de tipos documentais criados para registrar informações do acervo, como o resultado de um ato de sistematização dos registros e das informações. Nesse contexto, como já dito acima, é evidente que a faceta do "controle do acervo" figurou como a "razão de ser" por trás das definições da documentação nesse período. Outro aspecto a ser salientado, e que reforça o raciocínio aqui colocado, é que a discussão sobre documentação em museus nasceu do âmbito da prática profissional - surgiu antes, portanto, de uma discussão teórica sobre o tema. Em outros casos, a atividade de pesquisa de acervos de museus, ou de pesquisa acadêmica produzida em museus, é muitas vezes confundida com o próprio ato de documentar, como nos demonstra Georges Henri Rivière.

Esse uso difundido em contexto europeu traz à tona as semelhanças dos significados inicialmente atribuídos à ideia de documentação em museus com o que se discutia então no âmbito da disciplina Documentação. É possível entrever, por exemplo, a convergência das ideias de Yvonne Oddon com as de Paul Otlet sobre os aspectos práticos das técnicas da disciplina Documentação, e no reconhecimento da função da linguagem especializada para normalização dos conteúdos registrados nas fichas. Muito embora seja necessário lembrar que Paul Otlet não focou sua discussão nas implicações e desdobramentos da aplicação de tais técnicas nos museus, e nem Yvonne Oddon avançou nesse sentido.

A partir do exposto, é possível dizer que o termo documentação foi apropriado pela área de museus na sua dimensão de atividade e não na sua dimensão de área de conhecimento. Interpreta-se que os aspectos teóricos da área de estudos da Documentação não migraram necessariamente com o termo para a área de museus, apesar dessa disciplina já ter sinalizado, mesmo que não desenvolvido, que tal diálogo seria possível desde seus primórdios. Apesar de se considerar como um movimento possível a apropriação de um mesmo termo por diferentes áreas, e ainda que se admita a relatividade e pluralidade do seu significado, isso não implica que as 
discussões necessárias em torno dessa apropriação não devam ser feitas pelas áreas que se apropriam com aquelas das quais eles se originam.

O panorama histórico apresentado na primeira parte do capítulo também reforça essa hipótese. A literatura produzida na primeira metade do século XX sobre o assunto, tanto pelo CIDOC, quanto por autores europeus, estadunidenses e brasileiros, fala sobre documentação em museus de modo a descrever as atividades que devem ser feitas e os documentos que devem ser produzidos. Assim, a descrição revela detalhes de como a prática se operacionalizava e se operacionaliza em cada um dos contextos, e não exatamente a problematização dos conceitos embutidos nos significados das definições. É como se o conceito fosse algo implícito, sem necessidade de ser explicitado devido ao fato de ser de amplo conhecimento - tácito - dos leitores.

A literatura sobre documentação em museus continuou a ser produzida entre as décadas de 1970 e início de 1990, sob influência dos aspectos práticos do cotidiano dessas instituições. A bibliografia do período originada no Reino Unido e na Espanha se vale da ideia de sistema de documentação, atrelando o conceito de documentação a um fazer que se subdivide em partes inter-relacionadas. A ideia, especialmente na Espanha, era descrita e detalhada de modo a esclarecer as sequências entre as etapas do sistema e quais documentos deveriam ser utilizados em cada momento. No caso do Reino Unido, entre as etapas encontra-se também a preocupação com a organização da informação registrada, ou seja, a estruturação da recuperação da informação.

Todavia, os usos do termo documentação como sinônimo de um conjunto de atividades julgadas como necessárias para o controle do acervo - agora com o acréscimo da palavra sistema - não adentram em questionamentos acerca das implicações do próprio ato de documentar. Não apresentam explicações que permitem a interpretação da lógica que estrutura o sistema, como se conceitos inerentes ao ato - inventário, catalogação, objeto como documento - fossem, novamente, plenamente estabelecidos e a ação, em si, de organizar as informações, o resultado de uma metodologia consolidada. Em outras palavras, as literaturas europeia e brasileira produzidas entre as décadas de 1970 a 1990 abordadas aqui reiteram, com suas devidas e importantes exceções, uma natureza de manual de boas práticas sobre a documentação. Tal ponderação não busca desconsiderar a importância de tais publicações, mas apenas reconhecer seus objetivos principais - 
entre os quais não figurava imediatamente uma discussão teórica sobre documentação - e seus limites.

No final da década de 1990 e início de 2000, o que a literatura espanhola, por exemplo, reforça é a existência de um novo reposicionamento da questão da documentação no âmbito dos museus. O reposicionamento, conforme esclarece Marín Torres (2002), deriva de uma compreensão oriunda do contexto anglo-saxão sobre a documentação, que a interpreta como uma atividade que faz parte de um processo maior, a gestão das coleções. Nesse sentido, a gestão é entendida como um grupo de procedimentos destinados a aperfeiçoar as ações de organização e disponibilização das coleções institucionais, envolvendo desde técnicas de armazenagem, embalagem, transporte, conservação, avaliação, segurança e documentação.

Observa-se que no âmbito dessa tendência está também a ideia de gestão da informação, que permeia transversalmente todas as técnicas e procedimentos da gestão das coleções. É possível compreender que a abordagem anglo-saxônica possui duas frentes: a primeira, representada pelas questões impostas pela necessidade de assegurar a preservação física dos objetos; a segunda é representada pela orientação do trabalho a uma lógica integrada, que organiza a informação desde o momento em que o objeto chega ao museu até sua exposição ou a gestão da informação propriamente dita. Nesse âmbito, a documentação fica restrita à parte de controle físico das coleções, não cabendo mais a ela estipular a metodologia e os pressupostos teóricos para a estruturação da ação documental como um todo.

Outro ponto que merece ser abordado sobre a produção europeia e estadunidense é que a mesma foi produzida por autores de várias áreas de formação. São, em sua maioria, profissionais que atuam na área dos museus, com foco nas demandas cotidianas. Tal fato é destacado também por Marín Torres (2002), a qual explica que, na Espanha, profissionais de museus de arqueologia tiveram um envolvimento natural com as questões da documentação, tendo em vista a natureza da atividade arqueológica, que é classificatória e demanda alto grau de organização dos trabalhos de campo. Logo, o interesse em sistemas e normas de documentação dos elementos extraídos dos sítios e a preservação dessa informação pelos museus, que até hoje são o destino de muitos dos fragmentos arqueológicos. Daí, também é possível compreender que as contribuições oriundas 
desses autores são marcadas pela ênfase no estabelecimento de procedimentos de documentação e na estrutura dos dados - campos - a ser utilizada em cada procedimento, mais do que no conteúdo a ser registrado nessa estrutura.

Apesar da predominância de tal tendência, a convergência das discussões teóricas da Museologia e da Documentação está presente na contribuição de autores espanhóis e brasileiros apresentados neste capítulo, muitos deles museólogos com vínculos acadêmicos com a Ciência da Informação. Outro aspecto que vale salientar é que a produção que procura detalhar, ou mesmo ressaltar, a relação existente entre as três áreas em questão é recente: toda a produção consultada no presente trabalho e que parte dessa perspectiva integradora, data do final da década de 1990 até 2010, extrapolando o foco nas demandas de preservação das coleções que tem se consolidado como a tendência anglo-saxônica sobre 0 assunto.

Compreende-se que a abordagem da ideia de documentação feita por esses autores, por exemplo, difere daquela indicada por Rivière (1993), que considera documentação como sinônimo de pesquisa. Difere também das abordagens feitas por Oddon (1968) e propõe avanços em relação ao proposto por outros autores de origem europeia, porque procura estabelecer uma abordagem associativa entre os diferentes planos informativos dos acervos. Distancia-se, portanto, do foco sobre o controle físico da peça ou do suporte, predominante até então na literatura da área.

Embora usando terminologias diferentes, alguns autores brasileiros citados apresentam em seus textos uma influência direta de pressupostos teóricos da Ciência da Informação e da Documentação em suas concepções sobre documentação em museus. Bottallo (2000), da mesma forma que Ferrez (1991) e Ceravolo (1998), reconhece que a documentação em museus não se produz sozinha e não possui um fim em si mesma.

Além disso, tais autores chamam a atenção para a necessidade de revisitar a noção de documentação, para inseri-la em um contexto direcionado não apenas para a execução técnica de várias ações, mas, sobretudo, para a devolução social da informação à sociedade. Isso é algo que está presente em autores que se dedicam ao assunto documentação em museus como os espanhóis, a exemplo Gutiérrez Usillos (2010) e os brasileiros, como Ceravolo (1998, 2004), Ceravolo e Tálamo (2007) e Loureiro (2008). Autores como Smit (2010) também salientam a necessidade de se realizar as ações documentais nos museus com outra 
abordagem. Em outras palavras, a documentação para a área de museus, apesar da sua polissemia de se restringir como conceito mais ao universo dos museus ou como um paradoxo ainda a ser resolvido pela Museologia, demanda o que Nascimento (1994) e Ceravolo (2007) sinalizam, em períodos diferentes: o amadurecimento de uma base teórica e metodológica para o ato de documentar.

Hoje, particularmente no Brasil, a documentação é reconhecida como uma atividade que se estrutura a partir de pressupostos de estudos teóricos da Museologia. Ou seja, enquanto prática, precisa ser orientada por conceitos como o de objeto de museu e de museu, centrais para a própria Museologia. E se o objetivo é aproximar tal prática de aportes de outras áreas, é preciso que na sua execução sejam considerados os conceitos de documento e informação de disciplinas que a eles se dedicam, como a Documentação e a Ciência da Informação. Em, outros casos, os enfoques dados pela área apenas reforçaram o abandono de certas problemáticas, tendo em vista a ausência de consenso profissional, tecnologia, ou mesmo devido ao surgimento de novas perspectivas e temas predominantes.

No caso específico das discussões teóricas realizadas pela Museologia - que colocaram em observação conceitos centrais para a documentação, como as ideias de objeto, documento e musealização - é possível dizer que as mesmas correram em paralelo, não necessariamente encontrando eco na produção literária do mesmo período compreendido pelo levantamento. Em outras palavras, é possível perceber que são duas frentes de discussão - sobre teoria da Museologia e sobre as práticas de documentação em museus - que envolveram profissionais diferentes e objetivos distintos, sem necessariamente terem convergência.

Nessa discussão sobre a terminologia relativa à documentação, foi possível verificar ainda que, entre as variações identificadas, aquela que possui um número de ocorrências significativo no Brasil e se estabelece como um ponto de inflexão fundamental para o presente trabalho é documentação museológica. A partir das contribuições de autores que julgam como válida a expressão e aqueles que não veem sentido em seu uso atual é possível indagar: faria sentido falar em documentação museológica, ou documentação em museus, como é a escolha do presente trabalho?

Considera-se neste trabalho que a documentação museológica é uma definição ainda em processo de construção, de incorporação, análise e síntese conceitual. Quais seriam as áreas da documentação museológica? Seriam, por 
exemplo, Organização da Informação, tal como ocorre na Ciência da Informação? E quais seriam as metodologias da documentação museológica? Análise documentária, por exemplo? Seria o caso, então, da Museologia se apropriar ou assumir sua herança desses referenciais e verificar o que se adéqua frente aos seus paradigmas teóricos e da sua pragmática frente ao trabalho com o patrimônio musealizado?

Por considerar que essas questões ainda devem ser discutidas pelo próprio campo da Museologia é que se reforça a opção do presente trabalho, por ora, pela expressão "documentação em museus". Tal opção também permite que não se adentre em questões que ultrapassam os limites dessa pesquisa de mestrado e se disserte sobre um foco específico: o fazer documental realizado pelos museus, que envolve o processamento dos acervos, sua gestão cotidiana e também a tradução e comunicação desses conteúdos registrados sobre eles para o público.

Por fim, compreende-se que a documentação em museus nasceu como um fazer prático, estruturado a partir das contribuições de profissionais atuantes nas instituições, que se estruturou como uma atividade de perfil intermediário entre os universos teórico e prático - característica que pode ser considerada como herdada do movimento da Documentação. A documentação em museus é uma aplicação que deve extrair seus subsídios teóricos, principalmente, da disciplina Documentação. Essa observação se refere particularmente ao modo como a Documentação aborda metodologicamente as questões de representação de acervos por meio da linguagem, fornecendo subsídios para sua comunicação e interpretação. O ponto de partida para a estruturação desses sistemas ou modelos de representação é o próprio objeto, transformado em documento no contexto dos museus.

Conforme a discussão realizada no capítulo segundo, a aplicação do conceito de objeto como documento indica que documentá-lo não é um ato meramente burocrático. Para sua realização, há que se ter clareza do que se está denominando como documentação e quais são os desdobramentos conceituais e metodológicos a partir dessas escolhas. O objeto de museu, que é uma especificação dentro do conjunto de elementos da realidade, que pode ser considerado como objeto museológico, é algo que remete à malha relacional de conexões entre entidades, lugares, eventos e histórias de uso fora e dentro do museu. O objeto de museu é uma entidade complexa, que demanda que as informações sobre as dimensões as 
quais remete e pertence devam ser produzidas a partir de uma lógica documental orientada à comunicação.

A partir da revisão teórica realizada neste capítulo, é possível compreender a documentação em museus, enquanto conceito, como um processo contínuo, para fins de coleta, produção, recuperação e comunicação da informação sobre os acervos, ou dos acervos, para diferentes fins - técnicos, curatoriais e administrativos - e para diferentes usuários da instituição-museu. No contexto brasileiro, particularmente, a aproximação do termo documentação, enquanto conceito que encerra ideias associadas a uma prática, com as áreas da Documentação e da Ciência da Informação, é um passo necessário para o amadurecimento do debate, conforme sinalizado no segundo capítulo.

Ainda no esforço de caracterização da documentação em museus, enquanto atividade de aplicação, vale distingui-la da atividade de pesquisa. À luz do que se está considerando como válido especialmente para o contexto brasileiro, vale ressaltar que a documentação, nas suas diferentes etapas que articulam conceitos, é direcionada por objetivos e métodos de trabalho diferentes de pesquisa acadêmica. Diz isso porque se compreende que as atividades de pesquisa acadêmica - que obviamente podem envolver o acervo de um museu - geralmente possuem um tempo de maturação e produção de conhecimento, além de objetivos específicos que extrapolam a própria realidade institucional. Entende-se que a pesquisa acadêmica está calcada em um compromisso com uma disciplina de base, que pode fundamentar um museu, mas que a ele não se restringe. Além disso, os resultados da atividade de pesquisa - relatórios de pesquisa, diários de campo, artigos, anais de seminários, etc. - trabalham com outra forma de organização da informação e são direcionados para outros fins e meios de difusão da informação científica.

Já a atividade de documentação opera sobre o universo de informações gerado pela atividade de pesquisa para organizá-lo e representá-lo. Isso é feito para facilitar a recuperação dessas informações por diferentes usuários, e para contextualizar, dentro dos padrões selecionados para organização e representação, elementos da realidade que possuem semelhanças com aquilo que foi organizado e representado. Dito de outro modo, a documentação - em museus, pensando no presente trabalho - permite o processamento da informação gerada pelas áreas de especialidade, de modo a torná-la passível de ser usada em fichas de registro 
manuais, ou registros em bancos de dados sobre um acervo, por exemplo. Sua função é de mediação e criação de informação documentária, o que lhe confere uma natureza intermediária entre o fazer operacional e o intelectual. Nessa perspectiva, o documentalista é um profissional que trabalha pari passu ao pesquisador, pois cabe a ele pensar as formas de classificação, indexação e nominação das - no caso de museus - peças de um acervo, de modo a inseri-las em um contexto maior.

A documentação no ambiente dos museus, enquanto uma atividade que lida com elementos complexos da realidade social, ganha, assim, um estatuto igualmente complexo. Nesse sentido, fica clara também a importância do profissional responsável pela documentação em museus, cujas escolhas na produção da informação de natureza documentária não devem ser relegadas ao segundo plano. Logo, nessa revisita do conceito de documentar, compreende-se que para documentar um acervo de museu, o primeiro ato é a precisão do que se entende por documentação dentro de cada contexto, entendendo sempre que o objeto é algo com inúmeras nuances e será continuamente interpretado e reinterpretado.

Desse modo, o uso de referências de outros contextos é um procedimento válido e importante, mas que exige, acima de tudo, que se entendam as características da realidade onde as mesmas serão utilizadas. Tal procedimento torna-se igualmente necessário para validar os determinados conjuntos de conceitos e práticas dentro de suas próprias origens, com vistas a evitar equivalências equivocadas ou interpretações descontextualizadas da produção literária sobre o tema. Objetivaria também a evitar que se mantenha uma espécie de "circularidade acadêmica" (TÁLAMO; SMIT, 2007), em que as mesmas questões são discutidas e rediscutidas por diferentes autores, que por não considerarem os lugares de fala de cada um, acabam voltando a discutir velhas questões sem propor exatamente um avanço epistêmico.

Diante do exposto, compreende-se que restam ainda a fazer os detalhamentos das implicações do uso do termo em cada contexto da área de museus. Ou seja, o uso do termo documentação pela área de museus é lacunar e possui, ainda, forte viés prático vinculado ao seu significado. É com tal pressuposto que se passa para o próximo capítulo, dedicado a analisar as referências da SPECTRUM e do CIDOC dentro do panorama teórico construído até o momento. 


\section{O OBJETO EMPÍRICO: ANÁLISE SOBRE USOS DOS TERMOS DOCUMENTAÇÃO E DOCUMENTO NA SPECTRUM E NAS INTERNATIONAL GUIDELINES OBJECT INFORMATION: THE CIDOC INFORMATION CATEGORIES}

O presente capítulo é dedicado à caracterização do objeto empírico da pesquisa. Serão abordados os contextos de produção das International Guidelines Object Information: the CIDOC Information Categories e da SPECTRUM, bem como sua estrutura textual e as definições de documentação e objeto divulgadas por essas experiências. Ao final do capítulo, será feita uma análise comparativa entre os aspectos convergentes e divergentes dos dois modelos de referência, à luz da discussão teórica apresentada nos dois capítulos anteriores. Desse modo, objetivase primeiramente caracterizar as duas publicações enfocadas, a partir de determinadas categorias de análise estabelecidas para criar comparabilidade entre elas, e também inseri-las no contexto geral desta dissertação.

\subsection{SPECTRUM - Standard Procedures for Collections Recording used in Museums/The UK Museum Collections Management Standard (1994)}

Para comentar o contexto que deu origem à SPECTRUM, é importante fazer uma breve introdução ao modo como a área profissional de museus e as preocupações com documentação se estruturaram no Reino Unido. Como descrito no terceiro capítulo, a Associação Britânica de Museus, criada no ano de 1889, é considerada hoje a mais antiga associação profissional do tipo. Nasceu devido à inquietação existente entre os profissionais do Reino Unido que desejavam implantar um projeto de criação de um catálogo cooperativo padronizado para todos os museus e coleções não governamentais (LIGHT; ROBERTS; STEWART, 1986).

Apesar desse objetivo inicial claro, a Associação só voltaria a se dedicar com maior foco ao assunto de documentação na década de 1960, com o crescimento da preocupação dos museus com a necessidade de oferecer maior acesso às informações contidas em livros de registros, até então ordenados numericamente e em catálogos. Conforme explicam os autores Roberts, Light e Stewart (1986), essa 
preocupação era decorrente do avanço da informática e das novas possibilidades de recuperação da informação. Os principais líderes da retomada dessa discussão eram os curadores de coleções de ciência natural, que passaram a discutir padrões para os catálogos, de forma apartada da Associação, em um grupo de trabalho informal. Robert e Light (1986) explicam que esse grupo ficaria conhecido como o Grupo de Leicester, em alusão à Universidade de Leicester, onde foi realizado um seminário sobre o assunto em 1966.

Em 1967, a Associação Britânica de Museus e o Sheffield City Museum organizaram um colóquio que buscou discutir problemas envolvidos na recuperação da informação sobre as coleções de museu. O colóquio resultou na criação de grupos de trabalho que tinham o objetivo de examinar tópicos como preparação de padrões de dados e problemas de terminologia, fazendo com que o Grupo de Leicester se desfizesse e seus integrantes se incorporassem à nova iniciativa (ROBERT; LIGHT; STEWART, 1986).

Logo após o evento e a criação dos grupos de trabalho, foi instituído o Information Retrieval Group of the Museum Association - IRGMA. Esse grupo, de caráter voluntário, estabeleceu como preocupação central, além daquelas já estipuladas no colóquio de 1967, o desenvolvimento de sistemas de documentação viáveis para os museus. Para que isso fosse possível, o grupo realizou uma série de estudos sobre documentação, a fim de levantar subsídios para o desenvolvimento dos sistemas informatizados ou de sistemas manuais. Como um dos resultados dessa abordagem, o grupo decidiu investir no desenho de uma gama compreensiva de cartões de registro - record cards - , baseados em um grupo de princípios comuns extraídos das categorias que os museus já costumavam contemplar em seus registros e que servisse para ambos os tipos de sistema, manual ou informatizado.

Após quase dez anos de estudos e testes, o IRGMA publicou em 1976 oito cartões de registro, disponibilizados para a comunidade de museus mediante compra. Em 1977, o grupo envolvido com o IRGMA compreendeu que sua iniciativa demandava uma estrutura própria e o mesmo foi dissolvido dentro da Associação Britânica de Museus. Com esse desmembramento, foi fundada a Museum Documentation Association - a MDA. A MDA nasceu como uma entidade privada, na forma de agência (MATOS, 2012), contando com um corpo profissional próprio e sobrevivendo a partir de um orçamento baseado em doações de seus membros, 
recursos do governo e recursos gerados a partir de consultorias e outras assistências prestadas pelas equipes aos museus do Reino Unido. A MDA herdou todos os projetos e estudos do IRGMA e focou sua atenção na produção de um sistema de documentação integrado para museus - o Museum Documentation System ou MDS - e um pacote de aplicação do sistema para computadores.

Cumpre salientar que a MDA tem como uma de suas principais características a ênfase dada aos processos de informatização de acervos no Reino Unido, a ponto de estabelecer um Computer Bureau em 1979 destinado a disponibilizar serviços de processamento de dados. Como destaca Matos (2012), essa era a época dos mainframes, aos quais poucos museus possuíam acesso e que exigiam um alto grau de especialização técnica para operação. Nesse sentido, não era incomum que a MDA destinasse sua atenção para prestar esse tipo de serviço, já que ela própria necessitava que houvesse maior estrutura para a implantação do MDS. Como bem destaca Ceravolo (2007), e já ressaltado no terceiro capítulo, a década de 1970 foi marcada pela explosão da informática no mundo, o que também atingiu o universo dos museus, particularmente as instâncias dedicadas à documentação em museus, como o CIDOC e também a MDA.

Durante a década de 1980 e início da década de 1990, a MDA se envolveria com vários projetos de documentação, bem como lançaria uma série de publicações sobre: questões relacionadas à implantação de políticas de gestão da informação em museus, com o livro Information policies for museums, de autoria de Elizabeth Orna e lançado em 1987; padrões de modelo de dados, com o livro Museum Data Standard, lançado em 1991; e de procedimentos de gestão de acervo, como o livro Facts and artifacts: how to document a museum collection, de Stuart A. Holm, lançado também em 1991. Para Matos (2012), essa última publicação é importante, porque apresenta e explica quais são os procedimentos de gestão de acervo considerados essenciais em uma instituição - o que seria depois considerado como a base para parte dos procedimentos da SPECTRUM.

Em 1994, a MDA resolveu consolidar em um único documento o conhecimento gerado e acumulado ao longo de décadas de trabalho focados em documentação. Foi nesse ano que publicou a SPECTRUM - Standard Procedures for Collections Recording Used in Museums, com edição de Alex Grant. Como destaca Matos, o SPECTRUM "resultou do trabalho e contribuição ativa de um conjunto alargado de profissionais de museus, alguns envolvidos diretamente nos 
grupos de trabalho que deram origem à norma e referenciados nesta primeira versão" (MATOS, 2012, p. 105).

Nessa versão do documento são indicados vinte procedimentos e requisitos de informação (subdivididos em unidades de informação) necessários para cada procedimento. Também trouxe capítulos sobre utilização da SPECTRUM e sua implantação em museus, bem como questões legais associadas à informação e documentação das coleções. Para Matos (2012), tais características da estrutura da publicação foram determinantes para que a norma fosse aceita e implantada com sucesso no Reino Unido. O crescente interesse pela publicação, inclusive de fora do Reino Unido, levou a MDA a criar a segunda versão da norma no ano de 1997.

A segunda versão trouxe como principais mudanças a alteração da designação de alguns procedimentos, com expansão de seus significados, e a inclusão de novos procedimentos. Também trouxe a revisão da definição e o acréscimo de unidades de informação pertencentes aos requisitos de informação (MATOS, 2012). Segundo Matos (2012), essas modificações foram resultados da revisão do documento pela equipe da MDA, mediante o retorno obtido por meio dos usuários da norma, ou seja, o mesmo tipo de trabalho coletivo e colaborativo que marcou o nascimento da Associação.

Nos anos seguintes, a MDA ficou devotada ao lançamento de várias publicações relacionadas a questões específicas levantadas pela SPECTRUM e ao lançamento e estabelecimento da SPECTRUM Advisor Network, uma rede de profissionais de museus interessados no desenvolvimento e implantação da norma dentro do território britânico. A rede seria essencial para sua disseminação.

Em 2005, um ano após a nomeação de Nick Poole como diretor da MDA acontecimento fundamental para a mudança de rumo da Associação - foi publicada a terceira versão da SPECTRUM, apresentando a renomeação e reorganização de procedimentos existentes, criação de novos procedimentos e de uma nova seção para os grupos de informação, com "propósito de facilitar a consulta e utilização das unidades de informação, até aqui feita de forma dispersa" (MATOS, 2012, p. 107). Os grupos de informação passaram a agrupar as unidades de informação utilizadas nos procedimentos, que para essa versão foram integralmente revisados. Essa terceira versão teria dois desdobramentos em anos posteriores - as versões $3.1 \mathrm{e}$ 3.2 - que modificaram questões pontuais do texto original. 
Matos (2012) destaca duas situações relacionadas ao lançamento da terceira versão, dignas de comentário. A primeira é que, devido ao enorme impacto da SPECTRUM, muitas empresas de software se interessaram em desenvolver seus sistemas de forma compatível à norma. No mesmo ano de lançamento dessa nova versão, a MDA também lançou o SPECTRUM Partners Scheme para credenciamento das mesmas como compatíveis com as bases da SPECTRUM. Esse esquema é um arranjo de parceiros feito pela então Associação, para viabilizar o diálogo direto com fornecedores de softwares, tendo em vista a compatibilização de seus produtos com a SPECTRUM, por meio da avaliação de soluções existentes no mercado pela MDA.

A segunda situação é que em 2005 a norma já contava com uma adoção massiva pelos museus ingleses. O interesse internacional sobre a norma vinha crescendo significativamente, sendo alvo de debates em conferências do CIDOC e também de tradução para outros idiomas, a exemplo do alemão em 2007.

Em 2008, a MDA muda de nome para Collections Trust, adotando como missão auxiliar museus, galerias, bibliotecas e arquivos a explorar o potencial de suas coleções, por meio do compartilhamento de conhecimento e experiências em comum e, em segundo plano, promover o debate entre os maiores especialistas sobre o tema gestão de coleções em nível internacional. Segundo Matos (2012), esse movimento de mudança é derivado da internacionalização da SPECTRUM, que passa a contar cada vez mais com parcerias com instituições de diferentes países, tendo em vista a sua utilização pelas comunidades museológicas locais, bem como a participação em diferentes projetos internacionais, entre os quais se destaca a Europeana.

Vale ressaltar que o Collections Trust também possui uma série de programas e projetos de alcance nacional e internacional, assim como realiza eventos sobre as temáticas relacionadas à gestão de acervos. Entre esse, é possível destacar o Open Culture, que se define como uma conferência internacional que congrega anualmente profissionais de museus, fornecedores, especialistas, comunidade usuária da norma e equipes da organização para discutir os desafios atuais de gerenciamento de coleções ${ }^{19}$.

\footnotetext{
${ }^{19}$ Disponivel em: < http://www.collectionstrust.org.uk/openculture2014>. Acesso em: 27 jun. 2014.
} 
Em 2011, o Collections Trust lançou a quarta versão da norma. Nessa publicação, Matos destaca que a norma foi simplificada, através da:

\begin{abstract}
deslocação da informação sobre os aspectos legais específicos de cada procedimento para um capítulo específico sobre a legislação e políticas a considerar num processo de documentação, e da inclusão em cada um dos procedimentos de fluxos de trabalho em forma de gráfico que permitem uma compreensão mais fácil da norma e facilitam a sua implantação nos museus. (MATOS, 2012, p. 58).
\end{abstract}

Além disso, as duas partes principais estabelecidas na terceira versão foram mantidas, a dos procedimentos e a dos requisitos de informação. A parte sobre aconselhamento das versões anteriores também passou por alterações, sendo toda destinada às SPECTRUM Advice Factsheets. Nessa quarta versão, a tendência demonstrada já em 2005 se consolida: a norma deixa de ser centrada na documentação de coleções de museus e passa a se reportar à gestão de acervos, abarcando recomendações que vão além da "simples documentação" (MATOS, 2012, p. 109). Desse modo, a SPECTRUM se consolidou como uma norma de gestão de acervos, com vistas à sua internacionalização. É a estrutura dessa quarta versão que será alvo de maior detalhamento no tópico deste capítulo dedicado à análise comparativa entre as normas estudadas.

\title{
4.2. Apontamentos sobre a criação das International Guidelines Object Information: The CIDOC Information Categories (1995)
}

Para entender o caminho que levou à criação das International Guidelines Object Information: the CIDOC Information Categories - ou Diretrizes, como serão denominadas aqui - é válido antes conhecer alguns momentos da história do próprio comitê que as criou. Como já apresentado em capítulo anterior, o Comitê foi criado no ano de 1950 por profissionais ligados ao grupo fundador do ICOM, e herdou diretamente a preocupação já existente com padronização de informação em catálogos de acervos, particularmente os de museus de arte, da recém-extinta Oficina Internacional de Museus. Nesse início de atuação, destaca-se a atividade da documentalista e bibliotecária Yvonne Oddon, que secretariou o CIDOC durante muitos anos. 
Nos anos 1960, a atuação do CIDOC focou a realização de uma série de atividades destinadas à criação de modelos padronizados de fichas catalográficas e legendas para identificação de objetos (OLCINA, 1986). Como um exemplo desse período, é possível destacar novamente a elaboração, por Yvonne Oddon, da ficha classificatória polivalente - Oddon 1. O modelo dessa ficha, com outras referências julgadas por Oddon como relevantes para o registro de acervos, foi incorporado ao seu importante manual Elements de Documentation Museographique/Elements of Museum Documentation, publicado em 1968 após um curso dado por Oddon em Jos, Nigéria. Para os brasileiros, parte da estrutura dessa ficha está disponível no livro Museus: aquisição/documentação, de autoria de Fernanda de Camargo-Moro, publicado em 1986, conforme comentado no terceiro capítulo.

$\mathrm{Na}$ segunda metade da década de 1960, quando toda a área de museus se tornou consciente dos benefícios da informática na documentação das coleções, 0 CIDOC passou a se preocupar em coordenar as experiências em andamento para criação de sistemas computadorizados para museus. Segundo Olcina (1986), por volta de 1967, o CIDOC tentou criar um único sistema que pudesse abordar todos os outros, mas não teve o resultado inicialmente esperado. Já naquela época, as dificuldades de compatibilização se mostravam um desafio que chegaria até os dias atuais.

A partir desse cenário, o CIDOC iniciou um estudo para coleta e síntese de todos os sistemas espalhados ao redor do mundo. Tal trabalho demoraria anos para ser concluído e, apesar do esforço de todos os profissionais envolvidos, não foi possível consolidar um número específico de procedimentos que abarcassem todos os museus em sua heterogeneidade. Olcina (1986) destaca que, na mesma época no Reino Unido, o Information Retrieval Group of the Museum Association (IRGMA) lançou um formato mínimo com esse objetivo. E mesmo não atingindo todas as realidades, tal formato foi adotado pelo CIDOC como base para continuação do seu trabalho de síntese de sistemas e diretrizes sobre documentação (OLCINA, 1986).

Apenas em 1978, na Conferência Anual do CIDOC na cidade de Julita/Suécia, Peter Homulos e Robert G. Chenhall apresentaram o resultado desse trabalho de tantos anos: um conjunto mínimo de dezesseis categorias de informação, tidas como básicas para identificação de um objeto, para registro de sua história, de sua proveniência e de seu uso, para a atividade de inventários internos dos museus. 
A repercussão suscitada pelas dezesseis categorias indicadas levou o CIDOC a dar continuidade ao desenvolvimento do trabalho, que passou a ser concentrado, a partir do ano de 1980, em um grupo de trabalho denominado Documentation Standards. A parceria entre o CIDOC e membros da então MDA se firmou com esse trabalho, sendo notável a participação de Richard Light - MDA - na liderança desse grupo de trabalho, que tinha como propósitos atuar como fórum para discussão sobre padrões de dados de documentação em museus e elaborar uma referência flexível para descrição de tais padrões, de modo a facilitar seus desenvolvimentos e suas comparações (ROBERTS, 1996).

O CIDOC, no texto de apresentação das Diretrizes (CIDOC-ICOM, 1995), destaca que o período de 1980 e 1992 foi marcado pelo desenvolvimento intensivo de várias iniciativas paralelas para tornar possível abarcar todas as questões levantadas em 1978. Nesse período, o grupo de trabalho Documentation Standards seria subdividido, levando ao nascimento, posteriormente, de grupos de trabalho distintos - como o Data Standard e o Data Model. Entre as décadas de 1980 e 1990 há também uma preocupação do CIDOC com as questões de estudo e consolidação de terminologia, com a consequente constituição de grupos de trabalho dedicados à questão, conforme é relatado por Roberts e Fink (1990).

Outro exemplo que ilustra o interesse é o lançamento do Dictionarium Museologicum, projeto coordenado e mantido pelo CIDOC. É possível inferir que a publicação teve várias edições durante a década de 1980, de acordo com as consultas a plataformas de pesquisa de acervos bibliográficos do ICOM e da USP, cujos resultados apresentaram apenas edições com datas de publicação entre 1981 e 1986. Apesar do dicionário não trazer definições que delimitam o campo nocional da Museologia, traz diferentes conceitos utilizados pela área e como são designados em diferentes línguas, entre elas, o português. Todavia, vale ressaltar que essa publicação é de difícil acesso, por não possuir edições mais atualizadas e poucos exemplares disponíveis para consulta. Para a presente pesquisa foi possível consultar a edição de 1986, presente no acervo do Museu Paulista.

Em 1992, a ação dos grupos de trabalho resultou na apresentação de uma proposta de categorias de informação e de um modelo de dados para o registro das coleções na Conferência Trianual do ICOM, em Québec, Canadá. A proposta foi analisada pelos outros comitês internacionais do ICOM que sugeriram a criação de apenas um documento que consolidasse as boas práticas existentes, e que pudesse 
ser amplamente difundido entre as instituições. Seria o começo, de fato, da elaboração das Diretrizes.

Uniu-se à iniciativa o grupo Data and Terminology, então liderado por Toni Petersen, que vinha trabalhando em um modelo de categorias de informação para arte e arqueologia (MATOS, 2007). Esse grupo de trabalho passou a liderar as atividades de desenvolvimento das categorias a partir de 1992. Do mesmo modo, outros grupos especiais do ICOM foram chamados, como o dedicado ao estabelecimento do Conselho Internacional de Museus Africanos - AFRICOM. Em 1994, na Conferência Anual do CIDOC, o documento resultante desse trabalho foi apresentado. Em seguida, passaria por uma extensa revisão, de modo a contemplar não somente as categorias de informação, mas também convenções sobre formatos de entrada de dados e questões relativas à terminologia.

Por fim, em 1995, é lançada as International Guidelines for Museum Object Information: the CIDOC Information Categories, elaborada a partir da experiência de profissionais de várias regiões do mundo, mas principalmente dos Estados Unidos, Canadá, França e Reino Unido. Vale reforçar que as Guidelines ou Diretrizes como estão sendo chamadas aqui - nasceram não como um modelo único e universal sobre identificação de objetos de museus, mas como um ponto de partida. O motivo alegado pelos próprios coordenadores do projeto para terem renegado esse objetivo inalcançável foi sua inviabilidade na área de museus, que é extremamente heterogênea.

As Diretrizes colocaram na pauta do dia a pertinência de uma proposta que não se fecha nela mesma, mas facilita o crescimento de um trabalho e do uso convergente de vários padrões - de estrutura de dados, de terminologia, etc. - que se completam. Ou seja, no contexto de lançamento do documento, já era consenso do grupo elaborador que apenas um padrão não seria a resposta, e sim uma possibilidade, demonstrando avanços em relação ao objetivo primeiro que balizou as revisões decorrentes da proposta de 1978.

\subsection{Análise das Diretrizes do CIDOC e da SPECTRUM}

Com o objetivo de realizar a comparação entre as Diretrizes do CIDOC e a SPECTRUM, foi construído um quadro comparativo com diferentes categorias de análise. Tais categorias variaram entre questões ou aspectos relativos à estrutura 
formal de criação e estruturação do texto, até o levantamento de definições presentes nos glossários dos dois documentos. Desse modo, foi possível elencar, por meio das categorias de análise, as características comuns que podem ser observadas em ambos os documentos. Criou-se, assim, uma base concreta para a delimitação dos aspectos em que há uma aproximação evidente entre os documentos e aqueles que, apesar de presentes em ambos, conotam perspectivas distintas sobre documentação em museus.

O primeiro aspecto a ser ressaltado é o ano de lançamento das primeiras versões de cada documento. Ambas datam de meados da década de 1990 - a SPECTRUM em 1994 e as Diretrizes do CIDOC em 1995. A respeito disso, é possível tecer alguns comentários. Ao se considerar as trajetórias históricas do CIDOC e da então MDA que levaram à concepção, respectivamente, das Diretrizes e da SPECTRUM, pode-se inferir que os documentos nasceram em um período no qual as duas organizações expressavam o amadurecimento de discussões iniciadas na década de 1970 em torno de padrões e formatos mínimos para a documentação em museus (MATOS, 2012).

Nos dois casos, o que se observa não é a busca de um padrão universal para os museus, o que, segundo Grant (1996), foi uma tarefa que dominou a área de museus durante muito tempo, sem frutos concretos. O que se constata nos dois documentos é a busca de padrões e formatos mínimos, com base no entendimento de que, apesar das diferenças entre as coleções, as atividades de documentação necessitam de parâmetros básicos que permitam a recuperação de informação e o intercâmbio entre museus, e que garantam principalmente a segurança dos objetos.

Também é importante ressaltar que em nenhum dos dois casos é excluída a possibilidade de uso conjugado de outros padrões, tendo em vista que a heterogeneidade das coleções e das instituições que lhes dão contexto é extensa e demanda tal postura (GRANT, 1996). Em certa medida, o amadurecimento das discussões existentes desde a década de 1970, e que foram amplamente influenciadas pelo impacto da informática nos museus, trouxe para os documentos do CIDOC e da SPECTRUM o início de uma abordagem mais direcionada à relação entre gestão de acervo e gestão da informação sobre o acervo.

Conforme explanado no terceiro capítulo desta dissertação, é possível ressaltar também que a literatura existente sobre documentação nas décadas de 1980 e 1990 demonstra um cenário de compreensões diversas entre a literatura 
produzida no Brasil, na Espanha e no Reino Unido, por exemplo. Enquanto a produção de origem espanhola e parte da produção brasileira eram direcionadas para a definição de manuais procedimentais e instrumentos documentários - como inventários, fichas, formulários diversos, etc. -, a literatura de origem britânica consultada no presente trabalho (ROBERTS, 1985; LIGHT; ROBERTS; STEWART, 1986; ORNA, 1987; HOLM, 1991) apresenta a ideia de museum documentation system, indicando que o sistema não era relativo apenas ao estabelecimento de uma sequência padrão de etapas de trabalho e de padrões de instrumentos documentários - livros de registro, livros de tombo, fichas, formulários diversos, etc. - mas também ao tipo de informação a ser coletado, e ao como a informação coletada deveria ser registrada durante as etapas de trabalho. Em outras palavras, uma preocupação direta com a questão metodológica da gestão da informação sobre o acervo.

Prosseguindo na análise, é preciso destacar a origem das instituições responsáveis pelo lançamento das publicações. O CIDOC, como já preconiza em seu nome, é uma instância que desde seu início se projeta como internacional apesar da forte presença de profissionais europeus e da influência da abordagem anglo-saxã, característica esta que o próprio CIDOC tentou reverter nos anos posteriores ao lançamento das Diretrizes por meio da aproximação com profissionais de outros continentes, como a África (CIDOC-ICOM, 1996).

Vale salientar que a MDA nasceu para consolidar discussões inicialmente afeitas ao contexto do Reino Unido, sendo que o seu objetivo de internacionalização seria estabelecido somente anos depois do lançamento da primeira versão da SPECTRUM (MATOS, 2012). Nesse sentido, os dois documentos analisados podem ser considerados como resultados de uma construção coletiva de profissionais oriundos de diferentes museus e contextos, mas que mantém a predominância do raciocínio europeu, particularmente anglo-saxão, sobre documentação. Conforme abordado no terceiro capítulo, tal raciocínio se baseia em uma lógica destinada ao universo restrito do museu, buscando integrar as questões de controle com as questões relativas à produção de informação sobre o acervo. A abordagem permanece prática em sua essência, tendo em vista o seu objetivo de funcionar como um parâmetro para o cotidiano profissional das instituições museais, ficando a documentação vinculada ao aspecto de organização física da coleção. 
Em relação à atualização dos documentos, no caso das Diretrizes do CIDOC não houve modificações desde o seu lançamento em 1995. O contrário ocorre com a SPECTRUM: na medida em que a então MDA incorporou o desejo manifesto de se aproximar de outras realidades e tornar a norma uma referência internacional, foram sendo feitas novas versões do documento - que está agora na sua versão 4.0, lançada em 2011, como citado no início deste capítulo. As revisões realizadas ao longo dos anos incorporaram muito das sugestões e observações feitas pelos usuários da norma (MATOS, 2012), o que é possível entender como uma tentativa clara de abarcar contribuições de fora do Reino Unido.

O outro exemplo que reforça a existência de uma perspectiva anglo-saxã predominante nos dois documentos é a origem e o intercâmbio entre profissionais ligados ao CIDOC e à MDA. A origem dos editores responsáveis pelas primeiras versões dos documentos é predominantemente britânica e estadunidense, sendo que Alice Grant, editora da primeira versão da SPECTRUM, ainda figurou na primeira edição das Diretrizes do CIDOC. Além disso, em outras publicações, eventos e principalmente na ocupação do cargo de chair do CIDOC - que foi muitas vezes ocupado por profissionais ligados à diretoria da MDA - é possível perceber o estreitamento do relacionamento entre as duas organizações.

É possível também comparar os dois modelos quanto à sua existência enquanto norma. De acordo com a British Standards Institution - BSI -, uma norma pode ser entendida como:

\footnotetext{
uma forma acordada, repetível de se fazer algo. É um documento que contém uma especificação técnica ou outros critérios precisos desenvolvidos para serem utilizados consistentemente como uma regra, diretriz, ou definição. As normas tornam a vida mais simples e aumentam a confiabilidade e a efetividade de muitos produtos e serviços que usamos. Elas pretendem ser uma aspiração - um resumo de boas e melhores práticas em vez de uma prática geral. As normas são criadas formando um conjunto de experiência e conhecimento de todas as partes interessadas tais como os produtores, vendedores, compradores, usuários e regulamentadores de material, produto, processo ou serviço em particular. (GRUPO BSI, s/d).
}

A partir dessa concepção abrangente de norma, McKenna e De Loof (2009) explicam que há diferentes formas de classificar as mesmas. Uma delas é a classificação por tipo: as normas de jure e as de fato. As de jure são aquelas construídas e formalmente reconhecidas por instituições responsáveis pela regulação e estabelecimento de padrões, como a International Standards 
Organization - ISO -, ou no caso brasileiro, a Associação Brasileira de Normas Técnicas - ABNT. As normas de fato são aquelas não reconhecidas formalmente por nenhuma instituição, mas amplamente difundidas e aplicadas na área a qual se destina. Mckenna e De Loof (2009) também explicam que as normas podem ser classificadas quanto ao contexto de sua produção. Sendo assim, os autores elencam quatros categorias principais para divisão das normas: as in-house, criadas para uma instituição específica; as normas de comunidade, que, como diz o nome, atendem a objetivos específicos locais; as normas nacionais, elaboradas para aplicação dentro de um país; e as normas internacionais, reconhecidas e aplicáveis a vários contextos, geralmente difundidas por instituições normativas.

Ao trazer essa discussão para a área de documentação em museus, Matos (2012) explica que o cenário normativo da área de museus, ao contrário do que se pressupõe, não é caracterizado pela ausência de instrumentos e parâmetros, mas antes pela multiplicidade e complexidade de modelos. A multiplicidade, segundo o mesmo autor, se dá justamente pela diversidade de assuntos que a documentação em museus levanta e os interesses de cada grupo de profissionais e instituições envolvido no desenvolvimento das normas - ora com maior foco em discutir procedimentos de gestão, estrutura de dados ou terminologia, por exemplo.

Apesar da amplitude de possibilidades de normas, Matos (2012) chama também a atenção para o fato de que essa complexidade acaba levando à fragmentação e, às vezes, ao baixo reconhecimento das normas em contextos diferentes daqueles em que originalmente foram criadas. A ausência de certificação das normas elaboradas por entidades oficiais e internacionais é quase uma constante, o que também colabora para a pouca difusão dos modelos existentes - à exceção, talvez, dos esforços produzidos pelo CIDOC e, conforme a opinião do autor, do sucesso de internacionalização da SPECTRUM.

Feitas essas considerações, é possível inserir as Diretrizes do CIDOC e a SPECTRUM dentro desse cenário de diversidade normativa. Em um primeiro lugar, é possível dizer que, no caso do CIDOC, as diretrizes não são definidas na publicação como um padrão. Os editores da publicação definem as diretrizes, conforme já dito anteriormente, como um modelo de referência. Apesar disso, as Diretrizes do CIDOC podem ser consideradas como uma norma de fato e de natureza internacional, pois como afirma Matos (2012), elas são reconhecidas como uma estrutura mínima de dados que podem ser contempladas por diferentes 
museus, ainda que o CIDOC tenha definido o documento apenas como um modelo de referência.

Matos (2012) também ressalta que as Diretrizes do CIDOC foram extremamente importantes para o cenário dos museus ao redor do mundo. Embora não exista uma pesquisa feita pelo CIDOC a respeito da aplicação efetiva das diretrizes em projetos de documentação nos museus, é possível concordar com a inegável importância de considerá-las como uma espécie de mínimo divisor comum, no que se refere aos tipos de informação que devem ser produzidas sobre os objetos de um museu. Nesse sentido, as diretrizes se referem a um modelo de estrutura de dados que pode ser usado na construção de sistemas informatizados ou manuais de registro de informações sobre os acervos.

No caso da SPECTRUM, o Collections Trust o define como norma que nasce restrita ao universo dos museus do Reino Unido, e que tem buscado nos últimos anos se internacionalizar e se consolidar como um jeito de pensar museus (MATOS, 2012). Contudo, a SPECTRUM também pode ser classificado como uma norma de fato, pois não é reconhecida oficialmente como tal por nenhuma instituição reguladora - como a ISO ou o próprio BSI. Todavia, como no caso das Diretrizes do CIDOC, a SPECTRUM teve ampla aceitação e reconhecimento como um modelo a ser seguido. No caso da SPECTRUM, o foco do documento se refere aos procedimentos de gestão de acervo e aos requisitos de informação ou tipos de informação, que devem ser utilizados em cada um dos procedimentos.

Os documentos ora analisados fazem referência a outras normas que foram utilizadas em sua construção, demonstrando as bases formais que estruturaram os textos. No caso das Diretrizes do CIDOC, há a citação expressa do uso da norma ISO 8601-1988, que é a norma internacional para descrição de data e hora, para os casos em que a informação indicada no registro seja do tipo data. O documento também faz menção às normas ISO 5694/1985 e 2788/1986 - ambas Diretrizes de Documentação para Estabelecimento e Desenvolvimento de Tesauros Multilíngues. Porém, as Diretrizes do CIDOC não esmiúçam as questões relacionadas ao estabelecimento, desenvolvimento e manutenção em si de tesauros, pois se limitam a indicar, quando aplicável, a necessidade de utilizar vocabulário controlado para o registro de alguma informação.

No caso da SPECTRUM 4.0, no texto de apresentação do contexto legal e político da norma, há uma explicação por parte dos editores a respeito do 
relacionamento que a mesma possui com o PAS - Publicly Available Specification 197 que define o Code of Pratice for cultural collections management, publicado pelo BSI. Conforme explica Matos, um:

PAS, de acordo com o BSI, é uma norma informal, desenvolvida de acordo
com o modelo das normas do BSI, e baseada no consenso geral entre as
partes envolvidas na sua criação. A maior diferença de um PAS para um
British Standard é a não obrigatoriedade de incorporar, no primeiro, os
comentários e contribuições de todas as partes, permitindo assim a
construção rápida de uma norma de caráter consultivo e informal que
representa o primeiro passo numa área necessitada de normalização
formal. (MATOS, 2012, p. 121).

Segundo Matos (2012) o PAS 197 oferece um enquadramento mínimo a respeito do que deve ser considerado nas atividades de gestão de coleções culturais, o que engloba museus, arquivos e bibliotecas. Esse enquadramento ocorre na definição de quatro grandes eixos que uma política de gestão de acervo deve contemplar, sendo eles: 1) o desenvolvimento das coleções, Collections development; 2) a informação/documentação das coleções, Collections information/Documentation; 3) o acesso às coleções, Collections Access; e 4) a preservação e conservação das coleções, Collections Care and Conservation. O alinhamento da norma SPECTRUM ao PAS 197 acontece justamente no agrupamento dos procedimentos nesses quatro eixos, de modo a reforçar a importância das ações e dos processos reverberarem a missão da instituição.

A imagem abaixo, retirada do corpo do texto de apresentação de contexto legal e político da SPECTRUM, deixa clara a relação entre a norma e o PAS 197. Ela ilustra o alinhamento dos Procedimentos da SPECTRUM às orientações do PAS 197 sobre gestão de acervos. As palavras em itálico sinalizam os procedimentos de gestão de acervo considerados básicos pelo Collections Trust, e que devem ser comprovados pelos museus no momento em que os mesmos iniciam o processo de credenciamento no Reino Unido. 
Diagrama 1 - Alinhamento SPECTRUM e PAS 197.

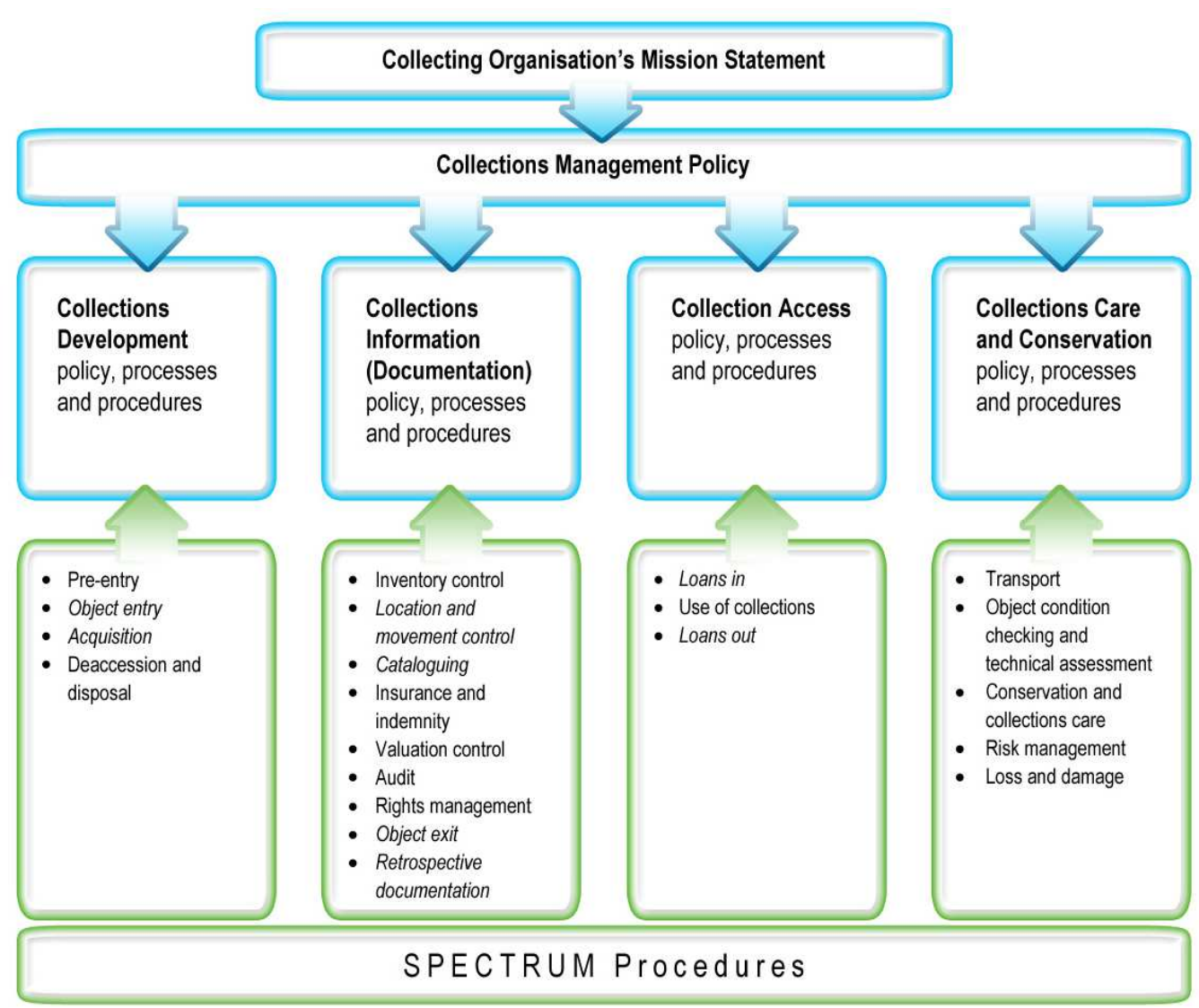

Fonte: COLLECTIONS TRUST, 2011b, p.8.

Além da adequação da proposta da SPECTRUM a uma especificação sobre gestão de acervos, o Collections Trust também indica a existência de outras normas que incidem diretamente sobre a sua implantação. As referências não estão no corpo principal da norma - que se denomina SPECTRUM Standard, mas no conjunto de fichas informativas que compõe os SPECTRUM Advice Factsheets e se intitulam Sources of help and advice. Nesse documento, o leitor pode encontrar a relação de outros PAS - especificações - e padrões que influenciam a documentação em museus, mas com forte ênfase para o que é válido no contexto britânico.

Em termos de estrutura do texto, os dois documentos apresentam diferenças significativas, que serão relatadas a seguir. 


\subsubsection{Detalhamento de estrutura textual e de definições presentes na SPECTRUM 4.0}

A SPECTRUM 4.0 apresenta uma estrutura composta de quatro partes distintas: a parte dedicada ao detalhamento dos procedimentos - denominada aqui de "Parte 1" e designada pelo Collections Trust de SPECTRUM Standard; a parte dedicada aos requisitos de informação, denominada oficialmente Appendix 1 Information Requirements, aqui identificada por "Parte 2"; e, por último, a parte destinada às SPECTRUM Advice Factsheets, já comentada no tópico anterior e que neste trabalho é denominada de "Parte 3". A "Parte 4" é aquela composta pela SPECTRUM Community, que reúne usuários, desenvolvedores de sistemas, profissionais do Collections Trust e demais interessados em fóruns virtuais sobre diferentes assuntos. As partes 1 e 2 estão disponíveis integralmente para download gratuito no site do Collections Trust, mediante concordância do interessado com os termos da licença de uso. A compra da versão impressa também é possível, mediante pedido on line. Parte dos componentes da parte 3 está disponível também para download gratuito e determinadas publicações só podem ser conseguidas se 0 interessado comprá-las.

A Parte 1 - SPECTRUM Standard - possui:

$\rightarrow \quad$ Introdução que comenta brevemente as modificações feitas na publicação e explica como os interessados no desenvolvimento de padrões podem participar dos grupos da organização, dando maior margem de colaboração para contextos não britânicos;

$\rightarrow \quad$ Um texto intitulado Política e Contexto Legal, onde são abordadas as questões de política de acervo e contexto legal do Reino Unido, as quais devem ser ponderadas na implantação da norma em um museu. Segundo informações constantes no site do Collections Trust e também comentadas por Matos (2012), esse texto é passível de modificação quando a norma é traduzida para outro idioma. A ideia é que ele espelhe as especificidades locais em termos de política e contexto legal das instituições, adaptando a 
SPECTRUM em termos linguísticos e culturais. O Collections Trust denomina esse processo de localização -localisation - da norma;

$\rightarrow \quad$ Um texto intitulado Como implantar um procedimento que introduz um passo a passo da implantação de um procedimento da norma em um museu;

$\rightarrow \quad$ Um texto intitulado Credenciamento e a SPECTRUM que aborda aspectos do processo de credenciamento de museus no Reino Unido, o qual envolve diretamente a comprovação da aplicação de 8 procedimentos da norma pelas instituições interessadas;

$\rightarrow$ E, por último, há a apresentação dos 21 Procedimentos que compõem a norma propriamente dita. Os procedimentos são:

- Pré-entrada;

- Entrada de objeto;

- Empréstimo-entrada;

○ Aquisição;

- Controle de inventário;

- $\quad$ Controle de localização e de movimentos;

- Transporte;

- Catalogação;

○ Verificação e avaliação técnica do estado de conservação;

- Preservação e conservação das coleções;

- Gestão de riscos;

- Gestão de seguros e indenizações;

- Controle de avaliação;

- Auditoria;

○ Gestão de direitos;

- Utilização da coleção;

- Saída de objeto;

- Empréstimo-saída;

- Perdas e danos;

○ Desincorporação e alienação; 
- Documentação retrospectiva.

As palavras em itálico dos itens acima sinalizam os 8 procedimentos básicos da SPECTRUM.

Para cada procedimento, há a seguinte orientação:

Definição - traz a explicação do escopo do procedimento.

Padrão mínimo - traz recomendações acerca de verificações que devem ser feitas sobre o que já está implantado no museu, ou sobre quais objetivos o museu deve procurar alcançar ao implantar aquele procedimento.

No detalhamento do procedimento, há sempre um diagrama workflow, que ilustra o relacionamento entre pessoas e instituições envolvidas, procedimentos relacionados e os tipos de informação requeridos. Os componentes dos processos de trabalho estão organizados em colunas, que se sucedem na seguinte ordem:

Entidades - People: entidades coletivas ou individuais, externas ou internas, que influenciam o processo.

Processo - Process: representação em diagrama das etapas de trabalho que compõem o processo relativo ao procedimento.

Procedimentos relacionados - Linked procedures: indica outros procedimentos que se relacionam de alguma forma com o procedimento em questão.

Informação - Information: lista os grupos de informação necessários para registrar os dados relativos a cada etapa do procedimento.

Sistema - System: só uma referência de que a SPECTRUM é um sistema de gestão de coleções por si só e "que cada procedimento deve ser considerado como parte integrante do mesmo" (MATOS, 2012, p. 126).

A imagem da próxima página traz um exemplo de diagrama de workflow utilizado em procedimentos da SPECTRUM e serve para facilitar a visualização do relacionamento entre as partes que compõem o procedimento, explicadas acima: 
Diagrama 2 - workflow de um procedimento da SPECTRUM.

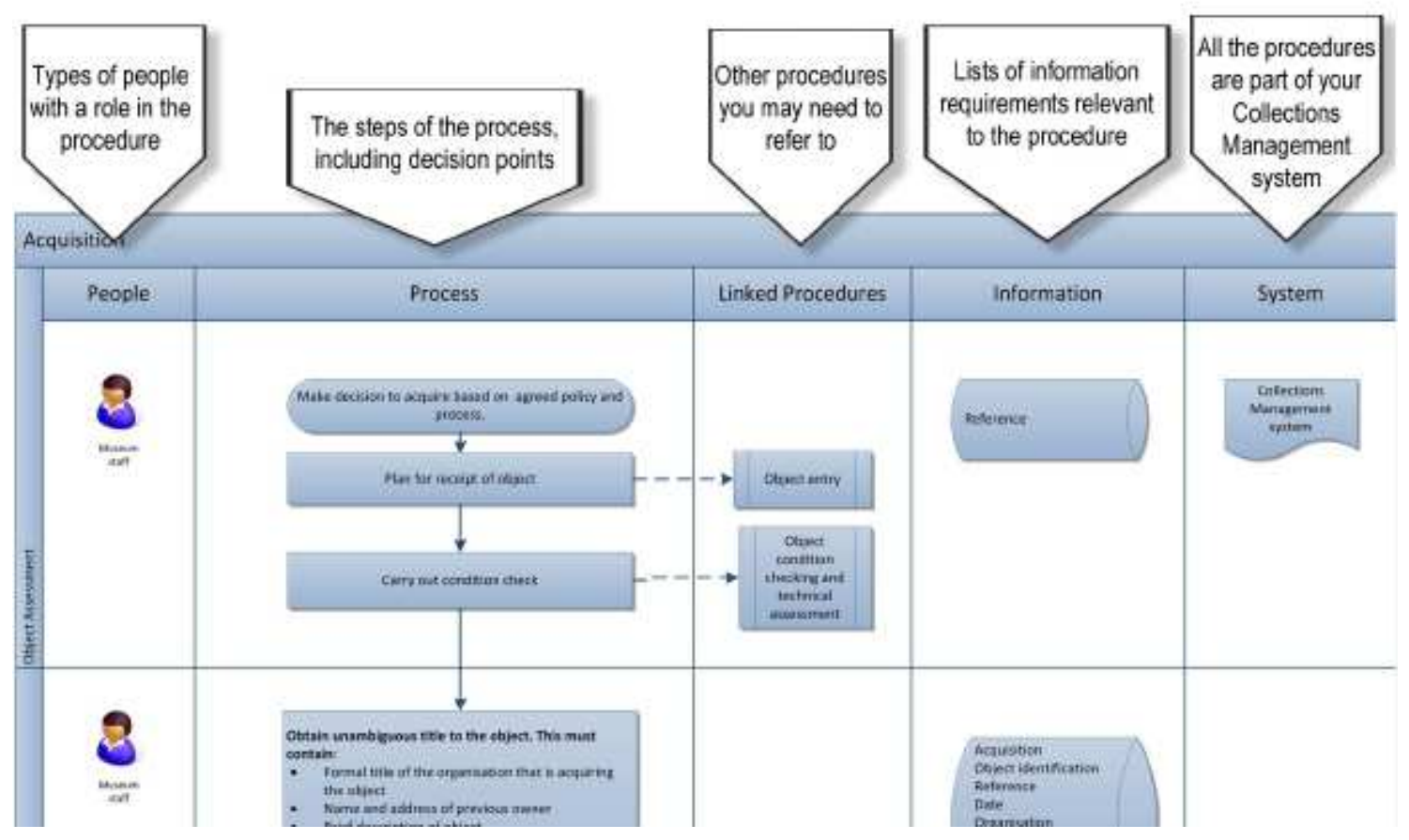

Fonte: COLLECTIONS TRUST, 2011b, p. 10.

É possível dizer que essa organização expressa a preocupação em correlacionar os procedimentos e as informações, de modo a deixar clara a importância da organicidade na execução das atividades de documentação e justificar a importância de cada uma delas. Nos procedimentos, observa-se também que a SPECTRUM procura indicar mais a forma como as atividades devem ser feitas e registradas, e menos a padronização do que deve ser registrado durante as atividades. Funciona, dessa forma, como uma guia relativa àquilo que não 'deve deixar de ser feito'.

A Parte 2 - Appendix 1 Information Requirements - Apêndice 1 Requisitos de Informação está dividida da seguinte forma:

$\rightarrow \quad$ Introdução, onde é explicado como está organizado o apêndice e há orientações sobre como correlacionar os procedimentos aos requisitos de informação; 
$\rightarrow \quad$ Apresentação dos 41 Grupos de informação usados na SPECTRUM. Cumpre ressaltar que três grupos - o de Objetos, Procedimentos e Gestão de Registros - aparecem com sua designação no plural por serem grandes concentrações de outros "grupos de informação", que são conjuntos de unidades de informação reunidas para registro de objetos, eventos, indivíduos, organizações, grupos culturais, datas e locais associados ao objeto. No caso específico do "supergrupo" de Gestão de Registros, ele está contido no grupo maior de Procedimentos. Por sua vez, a unidade de informação é o nível nuclear de informação, de caráter específico, e pode representar um campo em um sistema de informação. Compreende-se que essa estrutura em três níveis - "supergrupo", "grupo" e "unidade de informação" - corrobora, principalmente, para classificar as informações, dando-lhes contexto dentro dos fluxos previstos pela SPECTRUM. Desse modo, os grupos de informação são:

- Grupos de Informação de Objetos. Divididos em:

- Informação sobre auditoria de objeto;

- Informação sobre coleta de objeto;

- Informação sobre avaliação técnica e estado de conservação;

- Informação sobre conservação e tratamento do objeto;

- Informação sobre descrição do objeto;

- Informação sobre histórico do objeto e informação relacionada;

- Informação de identificação do objeto;

- Informação sobre localização do objeto;

- Informação sobre contribuições do proprietário do objeto;

- Informação sobre produção do objeto;

- Informação sobre requisitos do objeto;

- Informação sobre direitos sobre o objeto;

- Informação sobre exercício de direitos sobre o objeto;

- Informação sobre concessão de direitos sobre o objeto;

- Informação sobre uso de objeto;

- Informação sobre avaliação de objeto;

- Informação sobre contribuição de "observador" sobre o objeto. 
- Grupos de Procedimentos. Divididos em:

- Unidades comuns aos Procedimentos;

- Informação de Aquisição;

- Informação de Auditoria;

- Informação de Avaliação técnica / verificação do estado de conservação;

- Informação sobre Conservação e preservação das coleções;

- Informação de Alienação;

- Informação de Indenização;

- Informação de Seguro;

- Informação de Empréstimo - entrada;

- Informação de Empréstimo - saída;

- Informação de Perda / dano;

- Informação de Movimentação;

- Informação de Entrada de objeto;

- Informação de Saída de objeto;

- Informação do Processo;

- Informação de Avaliação;

- Informação de Uso das coleções;

- Informação de Endereço;

- Informação de Data;

- Informação de Localização;

- Informação da Organização;

- Informação de Grupo de pessoas;

- Informação de Indivíduo;

- Informação de Local;

- Grupos de Gestão de registro;

- Histórico de alterações;

- Uso e prestação de informação;

- Informação de registro;

- Informação de referências. 
Cada grupo é explicado da seguinte forma:

Designação do grupo - traz a designação adotada pela SPECTRUM para o grupo.

Definição da abrangência do grupo - logo abaixo da designação do grupo, há um texto que explica a abrangência do mesmo. Vale ressaltar que o texto não é claramente indicado como definição, mas é possível compreendê-lo como tal devido ao seu conteúdo.

Unidades de informação - traz a lista de todas as unidades de informação relacionadas àquele grupo.

$\rightarrow \quad$ Na sequência dos grupos, vem a Lista de Unidades de informação e designações de unidades não preferidas. Nesse tópico são apresentadas, em ordem alfabética, todas as designações adotadas oficialmente pela norma SPECTRUM e suas possíveis designações alternativas, criando assim relações de remissão entre termos preferidos e não preferidos. $\mathrm{Na}$ apresentação da lista, há a explicação de que a relação de remissão é necessária, pois os termos alternativos podem ser mais familiares aos usuários da SPECTRUM, do que aqueles convencionados pela norma;

$\rightarrow \quad$ Por fim, o Appendix ou "Parte 2" termina com a apresentação das Unidades de Informação propriamente ditas. As unidades de informação são apresentadas com a seguinte estrutura:

- Nome da unidade de informação: nome pelo qual é conhecida e identificada a unidade de informação;

- Definição: descrição breve do conceito da unidade, ou o seu escopo;

- Como registrar: orientações simples sobre como registrar a informação requerida pela unidade;

- Exemplos: exemplos do tipo de informação que pode ser registrada por aquela unidade;

- Utilização: identificação da relação existente entre a unidade de informação descrita e outras. Indica também a repetibilidade desse tipo de informação para cada registro; 
○ Grupo de informação: indicação do(s) grupo(s) de informação ao qual a unidade se vincula.

A Parte 3 - SPECTRUM Advice factsheets apresenta uma gama de materiais de referência que auxiliam na implantação e aplicação da SPECTRUM, mas também relativos a determinados projetos, experiências e metodologias existente no âmbito do Collections Trust estabelecidos a partir da norma, em uma perspectiva mais genérica. Os materiais de auxílio são:

A) De suporte à implantação dos procedimentos primários da SPECTRUM (factsheets):

- Object Entry - Entrada de Objeto SPECTRUM 4.0;

- Acquisition - Aquisição SPECTRUM 4.0;

- Location and movement control - Localização e controle de movimentação SPECTRUM 4.0;

- Cataloguing - Catalogação SPECTRUM 4.0;

- Object exit - Saída de objeto SPECTRUM 4.0;

- Loans in - Empréstimos - entrada SPECTRUM 4.0;

- Loans out - Empréstimos - saída SPECTRUM 4.0;

- Restrospective documentation and Making na inventory Documentação retrospectiva e Fazendo um Inventário SPECTRUM 4.0.

B) Suporte à aplicação da SPECTRUM:

- Labelling and marking museums objects - Etiquetagem e marcação de objetos de museus;

- Numbering - Numeração;

- Bulk accessioning - Incorporação de lotes ${ }^{20}$;

\footnotetext{
20 "Bulk accessioning" não tem uma tradução exata para o português, devido às peculiaridades do termo accession - incorporação - no contexto dos EUA e do Reino Unido. Pela tradição profissional desses lugares, o processo de entrada de um objeto se inicia, de modo geral, pela Acquisition aquisição -, que envolve desde o momento da entrada da peça pela instituição, até o momento em que se decide formalmente pela sua incorporação permanente ao acervo. É nesse momento que ocorre o registro oficial da peça, geralmente com um número identificador, tornando-a um "bem de uma coleção de museu" (BUCK; GILMORE, 2007, p. 13. Tradução da autora). A esse processo de
} 
- Glossary - Glossário - SPECTRUM 4.0;

- Sources of Help and Advice for SPECTRUM 4.0 - Fontes de Ajuda e Aconselhamento para a SPECTRUM 4.0 -, traz uma lista de referências legislativas e normativas que impactam as atividades de gestão de acervo no Reino Unido e, consequentemente, a implantação da SPECTRUM em um museu da federação britânica.

- Publicação Using SPECTRUM to sustain collection, traz cinco estudos de caso que ilustram como a SPECTRUM pode ser usada para melhorar e manter a gestão de coleções de museus do Reino Unido.

C) Publicações diversas:

- Publicação Documentation: a practical guide que apresenta orientações básicas e gerais sobre a atividade de documentação;

- Publicação Copyright: a practical guide que apresenta orientações básicas e gerais sobre as questões relacionadas aos direitos autorais relacionados às coleções;

- Ficha informativa (factsheet) intitulada Accession Records

- Registros de incorporação;

- Proposal for SPECTRUM 4.0, documento no qual o Collections Trust discorreu sobre os planos para o desenvolvimento da última versão da norma. Válido esclarecer que esse documento foi desenvolvido previamente ao lançamento da edição 4.0;

- DRAFT SPECTRUM Object Entry Procedure - Rascunho para o Procedimento de Entrada de Objeto da SPECTRUM -, que apresenta um diagrama de fluxo de trabalho

registro é que se costuma dar o nome de accession. Desse modo, "bulk acessioning" pode ser definido como o processo pelo qual se atribui, em lote, números de registro que permitem a incorporação definitiva de um grande grupo de objetos iguais ou semelhantes a um acervo. 
realizado pelo Collections Trust, no âmbito do plano de desenvolvimento da última versão da norma.

A "Parte 4" - SPECTRUM Community traz quatro grandes fóruns de discussão, dedicados ao desenvolvimento, "localização" - ou adaptação linguística e contextual -, promoção e suporte da SPECTRUM. Divide-se nos seguintes grupos:

$\rightarrow \quad$ SPECTRUM Users - Usuários da SPECTRUM;
$\rightarrow \quad$ SPECTRUM Champions - Campeões do SPECTRUM - grupo formado por voluntários que auxiliam no suporte nacional à norma SPECTRUM. Internacionalmente, são profissionais que geralmente dão suporte voluntário às ações de localização da norma;

$\rightarrow \quad$ SPECTRUM National Partners - Parceiros nacionais da SPECTRUM grupo formado por organizações públicas, ou sem fins lucrativos, que auxiliam o Collections Trust no desenvolvimento da norma em diferentes lugares do mundo;

$\rightarrow \quad$ SPECTRUM Partners - Parceiros da SPECTRUM - grupo formado por parceiros que desenvolvem softwares a partir das orientações da norma e fazem parte do SPECTRUM Partners Scheme.

Após esse detalhamento, é possível dizer que a SPECTRUM possui uma estrutura complexa, com muitas fontes a serem consultadas além da norma em si, para que se possa compreender a extensão da sua proposta. É importante ressaltar que a divisão da SPECTRUM em diferentes partes e documentos confere um alto nível de flexibilidade ao usuário, na medida em que o mesmo só consultará aquilo que tiver interesse imediato. Porém, só será possível a esse mesmo usuário reconhecer a extensão da SPECTRUM se conseguir consultar os recursos e outros materiais disponíveis. Isso implica, do ponto de vista do utilizador, uma constante atenção e retorno ao site do Collections Trust, na página dedicada à norma SPECTRUM, para verificação da existência de materiais de suporte atualizados - e que são importantes para compreender a complexidade da "Parte 1" da norma Isso, em uma primeira avaliação, não representa um problema, mas somente um ponto de atenção para o usuário da norma. 
Outro ponto que pode ser comentado a respeito da organização da SPECTRUM, principalmente no que se refere à "Parte 1", é que a norma estabelece uma abordagem relacional sobre os objetos e o próprio fazer documental dentro dos museus. Nesse sentido, como será possível constatar mais adiante, a SPECTRUM possui maior abrangência conceitual e metodológica do que as Diretrizes do CIDOC. A existência de diferentes grupos de informação que se destinam à descrição dos objetos, de eventos a eles relacionados, bem como datas, pessoas e lugares, é um exemplo claro de uma perspectiva multidimensional sobre o trabalho documental com os acervos e sobre o processo de criação de informação sobre o acervo.

Contudo, sua aplicação exige do usuário uma compreensão prévia a respeito das nuances ou multidimensões que estão em jogo, não sendo algo que está dado nos textos de apresentação do documento. É possível dizer que a SPECTRUM exige que o usuário compreenda a forma de pensar a documentação e, em nível mais genérico, a gestão dos acervos apresentada na norma, tendo em vista que em seus textos isso não está posto claramente. Sendo assim, é possível aprofundar a análise sobre duas definições centrais para o presente trabalho, e cuja discussão foi prevista como etapa metodológica da pesquisa: as definições de documento e objeto presentes na norma.

O glossário da SPECTRUM define documentação em museus - museum documentation - como:

Reunião e registro de informações sobre objetos, suas histórias e sobre os processos pelos quais eles passam dentro da instituição. O propósito da documentação é prestar contas, gerenciar e usar os objetos de modo a alcançar as metas e objetivos estabelecidos pela organização colecionadora (COLLECTIONS TRUST, 2011a, p. 1. Tradução da autora).

A definição proposta pela SPECTRUM estabelece que a documentação em museus - museum documentation - é, ao mesmo tempo, a designação que identifica a - ação de - coleta e o registro de toda informação sobre os objetos, suas histórias, associações e todos os processos aos quais os objetos estão relacionados dentro do museu. Em outras palavras, a documentação é tanto o processo de organização, quanto o resultado desse processo, o que reitera o entendimento de que há, na área de museus, a polissemia associada à palavra documentação. Conforme comentado no terceiro capítulo do presente trabalho, a polissemia de uma palavra é uma variação linguística esperada quando usada em diferentes contextos. 
Todavia, o contraponto de tal relatividade de significado no âmbito da terminologia de uma área - como a área de museus - é a constatação da dificuldade na realização de diálogos entre os contextos, devido às ambiguidades.

Ao comparar a definição presente no Glossário com a proposta de organização dos eixos de atuação de uma política de acervo do PAS 197 explicada anteriormente neste capítulo - o qual norteia a estruturação dos procedimentos da SPECTRUM em sua versão 4.0, percebe-se uma restrição de significado: a documentação é compreendida apenas como a informação relacionada às coleções - collections information. Dentro desse eixo estão os procedimentos de Controle de Inventário; Controle de Localização e Movimentação; Catalogação; Seguros e Indenização; Controle de Avaliação; Auditoria; Gestão de Direitos; Saída do Objeto; e Documentação Retrospectiva.

É possível entender que, diante desse cenário, a documentação foca muito mais os aspectos relativos ao controle interno da coleção, do que as questões relativas ao acesso, por exemplo. Em certo sentido, a preponderância da faceta de controle da documentação é coerente com a definição do Glossário, apesar da sua ambiguidade: nela está posto que o primeiro propósito da documentação é o de prestar contas a respeito da coleção, ou seja, ter o controle para dar a devida transparência ao uso dos recursos empregados na preservação da mesma. Como indicado no inventário realizado no terceiro capítulo acerca do termo documentação, compreende-se que a manutenção desse sentido reflete uma tradição de pensamento em torno da atividade de documentação.

Mais um aspecto importante a ser comentado é que outro termo aparece recorrentemente na SPECTRUM: gestão de coleções, que inclusive integra o título da norma. Apesar de não haver uma definição precisa do que é entendido por gestão de coleções na SPECTRUM, infere-se que a mesma é vista como o conjunto de procedimentos e processos pelos quais passa um objeto durante seu ciclo de vida em um museu (COLLECTIONS TRUST, 2011b). Percebe-se aqui uma coerência entre abordagem conceitual, que diferencia a gestão das coleções da documentação, e a tendência europeia apresentada por Marín Torres (2002), também comentada no terceiro capítulo: a de expandir a discussão sobre o processamento das coleções de museus sob a nova designação de gestão de acervos, ficando a documentação entendida como algo mais restrito ou até ultrapassado. 
Sendo assim, a gestão de acervos é algo que envolve não somente a identificação das peças, mas, sobretudo, a gestão da informação sobre eventos a elas relacionados, bem como pessoas, datas, lugares, etc. Também aqui é possível observar a coerência entre esse entendimento ampliado sobre gestão de acervos e consequentemente restritivo sobre a documentação - e a estrutura complexa de procedimentos e requisitos de informação sustentada pela SPECTRUM. Um exemplo que pode ser citado é o próprio detalhamento de todos os procedimentos e sua relação com os respectivos requisitos de informação - grupos e unidades de informação -, que direcionam os usuários ao registro normalizado de dados sobre eventos, pessoas, lugares e datas associados direta ou indiretamente aos objetos.

Embora seja necessário reconhecer o cuidado com que a SPECTRUM apresenta as conexões conceituais com sua proposta prática, fica ainda a questão a respeito do lugar da documentação. Em certa medida, interpreta-se como paradoxal, senão contraditório, o fato da documentação ser delimitada no glossário - Parte 4 como a coleta e o registro de praticamente qualquer informação associada ao objeto dentro do museu e, na norma em si - Parte 1 -, ser tratada como algo restrito a determinado conjunto de procedimentos. A gestão de acervos acaba sendo a definição que representa a perspectiva ampliada de envolvimento de todos os processos pelos quais passa um objeto durante sua estadia no museu, o que também poderia ser associado à definição de documentação ora em discussão.

A paradoxalidade da situação talvez resida na constatação de que, por mais que a SPECTRUM seja uma norma plenamente estabelecida como referência internacional de procedimentos para cuidar das coleções, não é possível refutar a inegável força de permanência desses mesmos conceitos e tradições profissionais e sua consequente influência - no âmbito dessas iniciativas. Em outras palavras, compreende-se que nem todas as experiências teóricas ou práticas/profissionais que propõem o avanço em determinados aspectos têm a força de, ou desejam conscientemente, romper com parâmetros estabelecidos dentro de uma área de atuação.

Tal constatação baseia-se nos resultados extraídos do levantamento bibliográfico sobre o termo documentação do terceiro capítulo desta dissertação ${ }^{21}$. 0 panorama traçado a partir do inventário demonstrou a grande variação de termos e

${ }^{21}$ Ver item 3.2 (p.73-102, Capítulo 3). 
significados para documentação no contexto dos museus, ocorrendo ao mesmo tempo e em lugares diferentes, não significando avanços propriamente ditos dentro do tema, mas antes a coexistência - e, em certa medida, talvez até concorrência de discursos específicos e nem sempre convergentes sobre documentação.

O glossário da SPECTRUM apresenta a seguinte definição de objeto, ou museum object:

\footnotetext{
Item que faz parte da coleção de uma organização: permanente (registrado no livro de registro de incorporações); para suporte; temporária (e.g: empréstimo); ou aqueles usados para manuseio educacional. (COLLECTIONS TRUST, 2011a, p. 2. Tradução da autora).
}

Observa-se que essa definição é bastante centrada no papel que o objeto desempenha dentro de uma instituição. Não entra em discussão sua natureza simbólica, que marca sua existência enquanto de museu. O objeto de museu, nessa abordagem, é o objeto que está no museu e faz parte de uma coleção - permanente ou temporária -, para cumprir determinados fins, tais como: pesquisa e exposição o que é possível inferir a partir da incorporação à coleção permanente, fins de suporte e também de manuseio educacional.

Do modo como é colocada a definição, fica implícito que o museu é uma figura de autoridade na definição do que é, ou não é, objeto de museu. Apesar do peso institucional do museu não poder ser subestimado, não há menção ao fato de que a transformação de um objeto em objeto de museu não é simplesmente uma consequência de o objeto ter entrado para uma coleção, mas o resultado de uma série de operações de seleção, processamento e representação ocorridas no âmbito das instituições, entre elas, a documentação e seus processos de coleta de informação.

Todavia, é necessário reconhecer que o objetivo principal da SPECTRUM não é promover uma análise ou crítica sobre a noção de documentação, e sim funcionar como uma proposta para a gestão de acervo. De todo modo, é possível identificar e refletir sobre os limites da norma e seus pressupostos conceituais básicos, pois mesmo que esses não sejam diretamente amparados em alguma teoria específica, expressam, implicitamente, uma forma de conceber a documentação. Logo, é válida a análise do texto e da proposta da SPECTRUM que aqui se realiza, devido às 
possibilidades da convergência entre o universo da prática, que é pela norma representada, e as discussões teóricas existentes sobre documentação em museus.

Ao delimitar o objeto de museu por esse ter entrado para a coleção de um museu, a definição recai antes em um entendimento que, provavelmente, refere-se unicamente à faceta material do objeto, ou seja, àquilo que é passível de ser controlado de forma imediata pelos instrumentos operacionais de documentação como o livro de registro de incorporações. A própria organização da lista de grupos e categorias de informação reforça essa compreensão de caráter mais restrito, como será possível detalhar em análise posterior.

É necessário aqui tecer uma crítica a esse entendimento, pois não é só pelo fato de um museu ter selecionado e incorporado algo à sua coleção que esse objeto será considerado um objeto de museu, ou um objeto musealizado. A natureza inerente a essa categoria demanda que sejam assumidas outras características em sua definição, sendo uma delas a transformação de caráter ontológico do objeto, que lhe traz novos significados e o coloca em outro contexto. É importante incorporar às definições da área, principalmente a de objeto, a necessidade de que essa transformação simbólica seja representada em diferentes formas e ações nos museus, muitas vezes valendo-se de operações baseadas na linguagem - o que permite citar a documentação novamente como exemplo.

Cumpre relembrar que a SPECTRUM possui 41 grupos de informação que são relativos aos objetos, aos procedimentos, aos endereços envolvidos no processo de gestão de acervo, às datas relacionadas ao mesmo processo, à localização do objeto, às pessoas e organizações, à organização que deteve ou detém o objeto, ao grupo de pessoas que possui relações com o objeto, ao indivíduo - idem -, ao local em que ocorrem as ações do processo de gestão de acervo, e à gestão de registro, com identificação de responsáveis e ações realizadas. Cada um desses grupos contém suas respectivas unidades de informação. São 17 os grupos de informação elencados para descrever um objeto, que se subdividem em várias unidades de informação. Nesse sentido, a análise da presente pesquisa focará apenas esse conjunto de grupos de informação dedicados ao objeto, tendo em vista a necessidade de criar parâmetros mínimos de comparabilidade entre a SPECTRUM e as Diretrizes do CIDOC, que se detém apenas sobre categorias de informação relativas ao objeto. 
Para uma primeira análise sobre os 17 grupos de informação dedicados aos objetos, optou-se por compreender como os mesmos são usados nos procedimentos e, por consequência, como se encontram classificados no âmbito dos quatro eixos de uma política de acervo adotados pela SPECTRUM - Formação da Coleção, Informação sobre a Coleção/Documentação, Acesso à Coleção, e Conservação e Preservação da Coleção. O objetivo dessa justaposição entre grupo de informação, sua aplicação nos procedimentos e em qual eixo os mesmos procedimentos se enquadram serviu para identificar, particularmente, que tipo de informação de objeto está associado ao eixo específico de Informação sobre a Coleção/Documentação.

Para ilustrar o raciocínio desenvolvido, o quadro abaixo foi desenhado. Nele, é possível compreender como os grupos de informação de objeto foram requisitados nos procedimentos e, ao mesmo tempo, em qual eixo de política de acervo o grupo de informação de objeto se relaciona, devido ao enquadramento do procedimento onde ocorre. Os procedimentos marcados em itálico são aqueles considerados básicos pelo Collections Trust, no seu esquema de credenciamento de museus no Reino Unido. 
Quadro 2 - Grupos de informação da SPECTRUM com referências aos eixos de política de acervo.

\begin{tabular}{|c|c|c|c|c|}
\hline $\begin{array}{l}\text { Grupos de Informação } \\
\text { de Objetos }\end{array}$ & $\begin{array}{l}\text { Formação da Coleção - } \\
\text { Procedimentos }\end{array}$ & $\begin{array}{l}\text { Informação sobre a } \\
\text { Coleção/Documentação - } \\
\text { Procedimentos }\end{array}$ & $\begin{array}{l}\text { Acesso à Coleção - } \\
\text { Procedimentos }\end{array}$ & $\begin{array}{l}\text { Conservação e Preservação da } \\
\text { Coleção - Procedimentos }\end{array}$ \\
\hline $\begin{array}{l}\text { 1) Informação sobre } \\
\text { auditoria de objeto }\end{array}$ & & Auditoria & & \\
\hline $\begin{array}{l}\text { Informação sobre } \\
\text { coleta de objeto }\end{array}$ & $\begin{array}{l}\text { Entrada de objeto; } \\
\text { Aquisição }\end{array}$ & & Empréstimos- entrada & \\
\hline $\begin{array}{l}\text { 3) Informação sobre } \\
\text { avaliação técnica e } \\
\text { estado de } \\
\text { conservação }\end{array}$ & & & $\begin{array}{l}\text { Empréstimos-saída; } \\
\text { Uso da coleção }\end{array}$ & $\begin{array}{l}\text { Avaliação técnica e verificação do } \\
\text { estado de conservação; } \\
\text { Conservação e preservação das } \\
\text { coleções; } \\
\text { Perdas e Danos }\end{array}$ \\
\hline $\begin{array}{l}\text { 4) Informação sobre } \\
\text { conservação e } \\
\text { tratamento do } \\
\text { objeto }\end{array}$ & & & Uso da coleção & $\begin{array}{l}\text { Conservação e preservação das } \\
\text { coleções }\end{array}$ \\
\hline $\begin{array}{l}\text { 5) Informação sobre } \\
\text { descrição do objeto }\end{array}$ & $\begin{array}{l}\text { Desincorporação e } \\
\text { alienação }\end{array}$ & $\begin{array}{l}\text { Catalogação; } \\
\text { Gestão de seguros e indenizações }\end{array}$ & $\begin{array}{l}\text { Empréstimos- entrada; } \\
\text { Empréstimos- saída }\end{array}$ & $\begin{array}{l}\text { Transporte; Conservação e } \\
\text { preservação das coleções }\end{array}$ \\
\hline $\begin{array}{l}\text { Informação sobre } \\
\text { histórico do objeto } \\
\text { e informação } \\
\text { relacionada }\end{array}$ & Aquisição & Catalogação & Empréstimos - entrada & \\
\hline $\begin{array}{l}\text { 7) Informação de } \\
\text { identificação do } \\
\text { objeto }\end{array}$ & $\begin{array}{l}\text { Entrada de objeto; } \\
\text { Aquisição; Desincorpo- } \\
\text { ração e alienação }\end{array}$ & $\begin{array}{l}\text { Catalogação; Controle de inventário; } \\
\text { Gestão de seguros e indenizações; } \\
\text { Controle de avaliação, } \\
\text { Gestão de Direitos }\end{array}$ & $\begin{array}{l}\text { Empréstimos- entrada; } \\
\text { Empréstimos - saída; } \\
\text { Uso da coleção }\end{array}$ & $\begin{array}{l}\text { Transporte; } \\
\text { Avaliação técnica e verificação do } \\
\text { estado de conservação; } \\
\text { Conservação e preservação das } \\
\text { coleções; } \\
\text { Gestão de riscos; } \\
\text { Perdas e Danos }\end{array}$ \\
\hline $\begin{array}{l}\text { 8) Informação sobre } \\
\text { localização do } \\
\text { objeto }\end{array}$ & Entrada de objeto & $\begin{array}{l}\text { Catalogação; Controle de localização e } \\
\text { de movimentos; Controle de Inventário; } \\
\text { Auditoria }\end{array}$ & $\begin{array}{l}\text { Empréstimos - saída; } \\
\text { Uso da coleção }\end{array}$ & $\begin{array}{l}\text { Conservação e preservação das } \\
\text { coleções; } \\
\text { Gestão de riscos; } \\
\text { Perdas e Danos }\end{array}$ \\
\hline
\end{tabular}




\begin{tabular}{|c|c|c|c|c|c|}
\hline 9) & $\begin{array}{l}\text { Informação sobre } \\
\text { contribuições do } \\
\text { proprietário do } \\
\text { objeto }\end{array}$ & & & & \\
\hline 10) & $\begin{array}{l}\text { Informação sobre } \\
\text { produção do objeto }\end{array}$ & & $\begin{array}{l}\text { Catalogação; Gestão de seguros e } \\
\text { indenizações }\end{array}$ & $\begin{array}{l}\text { Empréstimos- entrada; } \\
\text { Uso da coleção }\end{array}$ & \\
\hline 11) & $\begin{array}{l}\text { Informação sobre } \\
\text { requisitos do objeto }\end{array}$ & Aquisição & Controle de localização e de movimentos & $\begin{array}{l}\text { Empréstimos- entrada; } \\
\text { Empréstimos- saída }\end{array}$ & $\begin{array}{l}\text { Transporte; } \\
\text { Verificação e avaliação técnica do } \\
\text { estado de conservação; } \\
\text { Conservação e preservação das } \\
\text { coleções; } \\
\text { Gestão de riscos }\end{array}$ \\
\hline 12) & $\begin{array}{l}\text { Informação sobre } \\
\text { direitos sobre o } \\
\text { objeto }\end{array}$ & & Gestão de direitos & & \\
\hline 13) & $\begin{array}{l}\text { Informação sobre } \\
\text { exercício de } \\
\text { direitos sobre o } \\
\text { objeto }\end{array}$ & & & & \\
\hline 14) & $\begin{array}{l}\text { Informação sobre } \\
\text { concessão de } \\
\text { direitos sobre o } \\
\text { objeto }\end{array}$ & & & & \\
\hline 15) & $\begin{array}{l}\text { Informação sobre } \\
\text { uso de objeto }\end{array}$ & & & Uso da coleção & \\
\hline 16) & $\begin{array}{l}\text { Informação sobre } \\
\text { avaliação de objeto }\end{array}$ & & Controle de Avaliação & Empréstimos- saída & Transporte \\
\hline 17) & $\begin{array}{l}\text { Informação sobre } \\
\text { contribuição de } \\
\text { "observador" sobre } \\
\text { o objeto }\end{array}$ & & & & \\
\hline
\end{tabular}

Fonte: Juliana Monteiro, 2013. 
Como é possível visualizar a partir do Quadro 2, acima, a maioria dos 17 grupos de informação relacionados ao objeto aparece em procedimentos associados ao eixo de política de acervo dedicado ao Acesso à Coleção - 12 grupos -, seguindo-se daqueles que ocorrem no eixo Informação sobre a Coleção/Documentação - 9 grupos -, Conservação e Preservação da Coleção -8 grupos - e, por último, Formação da Coleção - 5 grupos. Vale destacar que 4 grupos de informação - aqueles relativos à contribuições do proprietário do objeto, sobre exercício de direitos sobre o objeto, sobre concessão de direitos sobre o objeto, e sobre contribuição de observador sobre o objeto - não são contemplados em nenhum procedimento da SPECTRUM.

O fato de que a maior parte dos grupos de informação é usada para registrar informações requisitadas pelos procedimentos vinculados ao eixo Acesso à Coleção poderia ser um indicador importante de que a norma não focaria somente as questões de controle físico da coleção. Sendo assim, esse indicador poderia significar, em uma primeira análise feita simplesmente a partir da quantidade de ocorrências dos grupos nos procedimentos e eixos, que a SPECTRUM se preocupa com a constituição de uma lógica de organização da informação que forneça subsídios para a difusão dos acervos. Ou seja, a informação sobre os objetos é muito mais direcionada para ações que visam a sua disponibilização para terceiros, do que só registrar uma descrição para uso interno da instituição que o preserva.

Porém, ao se analisar não somente a quantidade de grupos que ocorrem nos eixos, mas também sobre o que tratam os grupos, infere-se que a maioria se dedica a registrar informações sobre um objeto já incorporado a uma coleção. Os grupos que se dedicam aos outros períodos da vida do objeto antes dele se tornar de museu - como "Informação sobre história e associações do objeto", ou "Informação sobre produção do objeto" - são requisitados em um número menor de procedimentos, muito embora possuam um conjunto extenso de unidades de informação que lhes são vinculadas. E no caso do eixo de Acesso à Coleção, os dois grupos de informação citados são requisitados apenas nos procedimentos de Empréstimos- entrada e Uso das Coleções.

Em outras palavras, o que se infere é que, mesmo a SPECTRUM concentrando uma quantidade significativa de grupos de objetos no eixo relacionado ao Acesso à Coleção, as informações que reúnem não são relativas ao acesso ao conteúdo informacional que contextualiza a coleção. Em sua maioria, os grupos de 
informação associados ao Acesso são dedicados a identificar o objeto dentro da coleção. Desse modo, o Acesso é entendido aqui como o conjunto de procedimentos que permitem aceder fisicamente à peça para disponibilizá-la a outro museu, ou em uma exposição da sua própria instituição - o que reitera a ênfase dada ao controle e organização física da coleção da norma.

No que se refere aos 9 grupos solicitados nos procedimentos enquadrados no eixo Informação sobre Coleção/Documentação, observa-se a reprodução do mesmo caso dos grupos atribuídos ao eixo de Acesso: todos tratam de informações sobre controle e segurança física das coleções. A documentação é entendida essencialmente como o conjunto de procedimentos destinados à gestão interna da coleção - o que é condizente com a definição de documentação presente no glossário da norma. E que, assim como no caso dos grupos associados ao Acesso, reiteram os aspectos de regramento interno dos acervos inerentes às orientações da SPECTRUM.

Cumpre ressaltar ainda que o grupo de informação que aparece em todos os procedimentos é o Informação de Identificação de Objeto, cujas unidades de informação são compostas de dados relativos à identificação da peça dentro da coleção. Essa ocorrência possui lógica, pois os dados de controle sobre o objeto devem sempre estar presentes nos processos e instrumentos que o museu utiliza para registrar as ocorrências pelas quais ele passa. Ao passo que o grupo Informação sobre contribuição do proprietário, por exemplo, é sugerido pela SPECTRUM, mas não solicitado em nenhum procedimento específico. Portanto, os dados fornecidos pelo antigo ou atual dono sobre a peça, que são de natureza contextual, não estão previstos em nenhum momento dentro da norma. Resta o argumento de que, diante dessa organização, cabe ao museu decidir coletá-los ou não.

Sendo assim é possível reforçar, por último, que a SPECTRUM é uma norma importante no cenário atual dos museus e que se consolida como a referência a respeito de procedimentos e processos relativos ao dia a dia dos museus com seus acervos. Contudo, compreende-se que a norma opera com uma lógica de documentação restrita a determinados procedimentos e com um entendimento de objeto caracterizado em função de sua entrada para o museu. Em determinados aspectos, a SPECTRUM consegue sinalizar uma delimitação mais precisa do que seria a documentação em museus, mas, por outro lado, reitera tradições 
profissionais que caracterizam esse fazer como algo com forte tendência operacional, ligada ao controle das coleções.

Para compreensão e uso da norma, apesar da versão 4.0 contar com a ajuda dos diagramas que facilitam a visualização das relações entre procedimentos e requisitos de informação, é preciso que o usuário compreenda, ainda que em nível básico, toda a estrutura em torno da mesma - ou as partes, como foram denominadas aqui. Em outras palavras, para se familiarizar com as bases da SPECTRUM, que podem não ser suficientemente claras para um usuário iniciante, o mesmo pode se valer das explicações e material de referência contidos nas SPECTRUM Advice Factsheets.

\subsubsection{Detalhamento de estrutura textual e de definições presentes nas Diretrizes do CIDOC}

As Diretrizes do CIDOC possuem apresentação, prefácio, agradecimentos, introdução, glossário, uma explicação sobre os grupos de informação e, na sequência, a descrição dos grupos com suas respectivas categorias de informação propriamente ditas. Um grupo de informação é um conjunto que reúne - e também contextualiza - as categorias de informação que correspondem aos campos de uma ficha manual, ou que compõem uma estrutura de dados de um sistema informatizado. Ao observar tal organização do texto, é possível dizer que além das explicações sobre a abrangência dos grupos e categorias de informação - que serão detalhadas a seguir - o texto de introdução e o glossário são as únicas fontes de auxílio extra para compreensão das Diretrizes.

No texto de introdução estão definidos quatro objetivos específicos da documentação, a saber, a garantia:

- Da 'responsabilidade' sobre o acervo - accountability -, que se refere, nesse contexto, à demonstração por meio de relatórios, auditorias e prestação de contas, por parte do museu, de que cuida adequadamente do acervo e dos recursos que recebe para tanto. Um dos elementos que auxilia o museu a comprovar tal cuidado é a manutenção de um inventário atualizado de seu acervo (CIDOC-ICOM, 2014); 
- Da segurança do acervo - security -, que se refere ao cuidado do museu em manter informações atualizadas sobre a situação atual do objeto, além de fornecer descrições e comprovar a propriedade do museu sobre a peça (CIDOC-ICOM, 2014);

- Da formação de um "arquivo histórico" sobre a coleção - historic archive -, que se refere à constituição de um dossiê com informações sobre a produção, coleta, propriedade e posse dos objetos de um acervo - algo que as Diretrizes podem contribuir diretamente, por meio das suas categorias e unidades de informação (CIDOC-ICOM, 2014);

- Do acesso físico e intelectual à coleção - access -, que se refere ao apoio que as Diretrizes podem fornecer à estruturação de vias de acesso físico às peças, ou acesso às informações produzidas sobre elas.

Também é ressaltada a importância da documentação na preservação dos bens culturais contra roubos, furtos e outros tipos de crimes, conforme destacado pela Convenção da UNESCO de 1970, relativa às medidas a serem adotadas para proibir e impedir a importação, exportação e transferência de propriedades ilícitas dos bens culturais. É igualmente reforçado o papel da documentação na produção de conhecimento para além do objeto material, proporcionando fundamentos básicos para uso do acervo por curadores, pesquisadores e público em geral (CIDOC-ICOM, 1995). O texto procura esclarecer, por fim, as atribuições das Diretrizes. Entre as várias competências atribuídas ao modelo do CIDOC, está a possibilidade de ser usado como base para formulação de normas internacionais e nacionais para estabelecimento de projetos de documentação.

Além disso, o CIDOC evidencia o papel que as Diretrizes podem ter no intercâmbio de informações entre museus distintos, justamente por se definir como um ponto de partida prático. Outro aspecto interessante a ser comentando é que, ao se proporem como um modelo de partida, as Diretrizes também se colocam como base para realização de diferentes etapas do trabalho prático da documentação, como o inventário - que seria direcionado para as informações básicas de gestão de acervo relacionadas a cada objeto -, ou para catalogação completa da coleção - 
entendida aqui como a ação de registro mais detalhado e que envolve informações adicionais relacionadas à história dos objetos.

Dá-se ênfase, portanto, à sua flexibilidade enquanto modelo que visa "corroborar as necessidades de todas as disciplinas existentes em museus, incluindo arqueologia, história da cultura, arte, ciência e tecnologia, e ciências naturais" (CIDOC-ICOM, 1995, p. 20. Tradução da autora). O que se infere de tal afirmação é que as Diretrizes objetivam ultrapassar uma questão que muitas vezes é apontada no universo da prática profissional como algo intransponível: a realização da documentação seguindo os conceitos e metodologias únicos das disciplinas de base de cada museu. Se isso por um lado é uma variável que precisa ser considerada até os dias atuais - principalmente nos aspectos de interpretação dos acervos, as Diretrizes reforçam, mesmo que indiretamente, a possibilidade para a construção de caminhos interdisciplinares no exercício da documentação em museus. Isso não implica a sobreposição de especificidades disciplinares, mas reforça, antes, a existência equivalente dos saberes específicos da documentação na organização da informação sobre os acervos de museus.

O glossário das Diretrizes é composto de 26 termos e siglas que aparecem ao longo do documento, entre eles a definição de documentação e objeto de museu, cujos significados constituem um dos alvos da presente dissertação. Foi possível identificar que a expressão utilizada nas Diretrizes é museum documentation documentação de museu -, que, conforme já explicado no terceiro capítulo deste trabalho, ainda não possui uma tradução específica para o português. Em seu glossário, museum documentation significa:

\footnotetext{
Os registros que documentam a criação, o histórico, a aquisição pelo museu e a história subsequente de todos os objetos do acervo. Esses registros incluem documentos de proveniência e origem, documentos de aquisição, relatórios de conservação, registros de catalogação, imagens e pesquisas, sendo criados pela instituição detentora do objeto, proprietários anteriores, pesquisadores independentes etc. $O$ termo também se aplica ao processo de coleta dessas informações. (CIDOC-ICOM, 1995, p. 24. Tradução e grifo da autora)
}

Identifica-se aqui a mesma equivalência do entendimento de documentação como processo e o resultado do processo - os registros -, tal como foi igualmente identificado em outras fontes da literatura existente no âmbito do inventário realizado sobre o termo documentação no terceiro capítulo. A definição museum 
documentation do CIDOC se delineia como atividade que gira em torno da coleção do museu e se infere que possua uma metodologia específica para duas ações: a coleta de informações e o gerenciamento dos documentos que lhes dão suporte relatórios, fichas, registros diversos, imagens, etc. Não se encontra, em nenhum momento do texto, alguma referência a uma proposta teórica ou fundamentação de base que oriente a documentação - o que, como no caso da SPECTRUM, não figura como objetivo central do documento. Desse modo, é possível entender, devido a essa ausência, que a documentação se encontra restrita a um conjunto de procedimentos operacionais para a identificação de um objeto.

Apesar de incluir a ideia de processo de coleta na definição, vale ressaltar que o CIDOC, nesse caso, se alonga na descrição de tipos de documentos que 'constituem' a documentação e não entra em detalhes sobre o que consistiria esse processo, nem como seria a metodologia adequada para a coleta de informação. A descrição dos tipos pode ser relacionada à ênfase dada aos registros / instrumentos documentários, para utilizar um termo que remonta à concepção de documentação de Yvonne Oddon (1968), e que reforça a compreensão apresentada acima. Essa ênfase, que inicialmente poderia passar despercebida, talvez possa ser interpretada como um indício de paradoxalidade da definição.

De modo semelhante ao caso da SPECTRUM, a característica paradoxal da definição está na verificação de que, por mais que as Diretrizes se configurem como um avanço na discussão sobre parâmetros para a documentação em museus dentro e fora do CIDOC, também aqui não é possível refutar a inegável força de permanência desses mesmos conceitos e tradições profissionais no âmbito do documento ora analisado.

No caso da definição do CIDOC, é possível observar esse movimento de coexistência de perspectivas não necessariamente contraditórias, mas que apontam caminhos e enfoques diferentes sobre o fazer documentação em museus. Esses mesmos elementos comentados aqui estão refletidos em outros momentos da publicação, como será possível observar na análise dos grupos e categorias de informação. Sendo assim, pode-se dizer que as Diretrizes tratam de aspectos práticos da documentação e se propõem a especificar o tipo de informação a ser coletado no cotidiano da gestão de uma coleção, e qual o seu formato. Ressalta-se que tal consideração deve ser um ponto de atenção quando do uso das mesmas em outros contextos, nos quais a documentação nos museus possui uma abordagem 
diferente daquela praticada em países do universo anglo-saxão, que marca a origem das Diretrizes. No caso do Brasil, que possui uma abordagem sobre documentação que a insere no âmbito das discussões teóricas sobre a área da Museologia, o uso das definições apresentadas pelo CIDOC nas Diretrizes, bem como de sua proposta de abordagem descritiva do objeto, deve ser analisado frente às realidades organizacionais e teóricas existentes.

No que se refere à definição de museum object - objeto de museu -, as Diretrizes do CIDOC apresentam uma definição genérica, a saber:

\begin{abstract}
Item que faz parte da coleção de uma instituição de forma permanente (neste caso, sendo registrado no cadastro de incorporações do museu) ou temporária (por exemplo, depósito ou empréstimo). O termo "Espécime" é usado para coleções de história natural e neste documento os dois termos devem ser considerados como intercambiáveis. (CIDOC-ICOM, 1995, p. 24. Tradução da autora)
\end{abstract}

A definição de objeto apresentada pelo CIDOC, devido ao próprio caráter do documento, não problematiza ou caracteriza a natureza do objeto de museu enquanto um signo, com faceta material e imaterial. Limita-se a defini-lo pela sua institucionalização. Da mesma forma como ocorre na SPECTRUM, o objeto de museu, nessa abordagem, é o objeto que está no museu.

Ou seja, faz-se aqui a ressalva da importância de relativizar esse entendimento, pois não é só pelo fato de um museu ter selecionado e incorporado algo a sua coleção que esse objeto será considerado um objeto de museu. Conforme abordado no terceiro capítulo, em outros contextos, a natureza inerente dessa categoria objeto de museu demanda que sejam assumidas outras características em sua definição, sendo uma delas a transformação de caráter ontológico do objeto, que lhe traz novos significados, como é o caso do Brasil. Tal abordagem sobre o objeto de museu só reforça a necessidade de que essa transformação simbólica seja representada em diferentes formas e ações nos museus, muitas vezes se valendo de operações baseadas na linguagem - o que permite citar a documentação novamente como exemplo.

Prosseguindo na análise, no documento do CIDOC são 22 os grupos de informação elencados para descrever um objeto, que se subdividem em várias categorias. Os grupos de informação são dispostos no documento de modo a articulá-los a uma, ou mais, das quatro funções ou objetivos atribuídas à 
documentação, indicados acima. De certa forma, o enquadramento dos grupos e suas respectivas categorias em um ou mais objetivos da documentação reforça a importância das informações registradas e processadas documentalmente. Desse modo, é possivel apresentar o relacionamento entre objetivos da documentação, grupos e categorias de informação, conforme o Quadro 4, abaixo. Sobre o quadro, é válido ressaltar que as siglas utilizadas para representar as finalidades foram mantidas como no original em inglês: Security - Sec; Accountability - Acct; Access Ac; e Historic Archive - HistA. Os nomes dos grupos e unidades de informação constam conforme em CIDOC (2014). 
Quadro 3 - Grupos de informação do CIDOC e suas finalidades.

\begin{tabular}{|c|c|c|}
\hline $\begin{array}{c}\text { Associado às finalidades de: } \\
\text { Segurança - Sec } \\
\text { Responsabilidade - Acct } \\
\text { Acesso - Ac } \\
\text { Arquivo Histórico - HistA }\end{array}$ & Grupos de informação & Unidades de informação associadas \\
\hline Sec, Acct & Grupo de informação sobre aquisição & $\begin{array}{l}\text { Método de Aquisição } \\
\text { Data de Aquisição } \\
\text { Fonte de Aquisição }\end{array}$ \\
\hline Sec, Acct, Acc & $\begin{array}{l}\text { Grupo de Informação sobre baixa patrimonial e } \\
\text { alienação }\end{array}$ & $\begin{array}{l}\text { Data da baixa patrimonial } \\
\text { Data de alienaçãao } \\
\text { Método de alienação } \\
\text { Destinatário da alienação }\end{array}$ \\
\hline Acct, Acc & Grupo de informação sobre instituição & $\begin{array}{l}\text { Nome da instituição } \\
\text { Subdivisão da instituição } \\
\text { Endereço da instituição } \\
\text { País da instituição }\end{array}$ \\
\hline Sec, Acct, Acc & Grupo de informação sobre localização & $\begin{array}{c}\text { Localização atual } \\
\text { Tipo de localização atual } \\
\text { Data da localização atual } \\
\text { Localização usual }\end{array}$ \\
\hline
\end{tabular}




\begin{tabular}{|c|c|c|}
\hline Sec, Acct, Acc & Grupo de informação sobre marca e inscrição & $\begin{array}{l}\text { Texto da marca / inscrição } \\
\text { Tipo da marca / inscriçãoo } \\
\text { Descrição da marca / inscrição } \\
\text { Técnica da marca / inscrição } \\
\text { Posição da marca / inscrição } \\
\text { Idioma da marca / inscrição } \\
\text { Tradução da marca / inscrição }\end{array}$ \\
\hline Sec, Acc, HistA & Grupo de informação sobre material e técnica & $\begin{array}{c}\text { Material } \\
\text { Técnica } \\
\text { Descrição de parte ou componente }\end{array}$ \\
\hline Sec, Acct, Acc & Grupo de informação sobre medição & $\begin{array}{l}\text { Dimensão } \\
\text { Medição } \\
\text { Unidade de medida } \\
\text { Parte mensurada }\end{array}$ \\
\hline Acc, HistA & Grupo de informação sobre associação de objeto & $\begin{array}{c}\text { Local associado } \\
\text { Data associada } \\
\text { Nome de grupo / indivíduo associado } \\
\text { Tipo de associação } \\
\text { Função original }\end{array}$ \\
\hline Sec, Acct, Acc, HistA & Grupo de informação sobre a entrada de objeto & $\begin{array}{l}\text { Proprietário atual } \\
\text { Depositante } \\
\text { Data de entrada } \\
\text { Número de entrada } \\
\text { Motivo de entrada }\end{array}$ \\
\hline
\end{tabular}




\begin{tabular}{|c|c|c|}
\hline Acct, Acc, HistA & Grupo de informação sobre nome de objeto & $\begin{array}{l}\text { Nome de objeto } \\
\text { Tipo de nome de objeto } \\
\text { Autoridade do nome de objeto }\end{array}$ \\
\hline Sec, Acct, Acc & Grupo de informação sobre número de objeto & $\begin{array}{l}\text { Número de objeto } \\
\text { Tipo de número de objeto } \\
\text { Data do número de objeto }\end{array}$ \\
\hline Sec, Acct, Acc, HistA & Grupo de informação sobre produção de objeto & $\begin{array}{l}\text { Local de produção } \\
\text { Data de produção } \\
\text { Grupo produtor / indivíduo produtor } \\
\text { Função na produção }\end{array}$ \\
\hline Sec, Acc, HistA & Grupo de informação sobre título de objeto & $\begin{array}{c}\text { Título } \\
\text { Tipo de título } \\
\text { Tradução de título }\end{array}$ \\
\hline Sec, Acct, Acc & Grupo de informação sobre parte e componente & $\begin{array}{l}\text { Número de partes ou componentes } \\
\text { Descrição de partes ou componentes }\end{array}$ \\
\hline Acct, Acc, HistA & Grupo de informação sobre referência & $\begin{array}{l}\text { Referência } \\
\text { Tipo de referência }\end{array}$ \\
\hline Acct, Acc & Grupo de informação sobre direitos de reprodução & $\begin{array}{l}\text { Nota sobre direitos de reprodução } \\
\text { Proprietários dos direitos de reprodução }\end{array}$ \\
\hline Acc & Grupo de informação sobre assunto representado & $\begin{array}{l}\text { Assunto representado } \\
\text { Descrição de assunto representado }\end{array}$ \\
\hline
\end{tabular}

Fonte: Juliana Monteiro, 2013. 
Os grupos de informação das Diretrizes do CIDOC são apresentados em ordem alfabética, de acordo com a grafia das palavras em inglês. Para cada um, o documento traz uma explicação que o relaciona a alguma das finalidades definidas para a documentação - tal como apresentado no Quadro 3, acima. Na sequência, há a indicação das categorias de informação que lhe são vinculadas, com exemplos de aplicação e notas adicionais que servem para orientar o usuário em caso de alguma especificidade relacionada ao grupo. Posteriormente, as categorias pertencentes àquele grupo são detalhadas, em uma estrutura semelhante à do grupo: com nome alternativo, definição, exemplos de aplicação e notas. Para ilustrar o que foi explicado, a organização dos grupos e das categorias é apresentada abaixo, conforme consta nas Diretrizes:

\section{$\rightarrow \quad$ Grupos de informação:}

Propósito: explica porquê aquele grupo de informação é importante e qual dos quatro critérios de documentação definidos pelo CIDOC o grupo atende.

Categorias de informação: indicam quais são as categorias de informação reunidas no grupo de informação.

Exemplos: dá exemplos de como as categorias de informação inclusas no grupo são usadas juntas.

Notas: são usadas para tratar de assuntos variados, entre eles se o grupo de informação pode ser usado mais de uma vez em um único registro e recomendações, e sugestões para implantar o registro do Grupo de Informação em um sistema, se apropriado.

\section{$\rightarrow \quad$ Categorias de informação:}

Nome alternativo: lista não exaustiva de outros nomes pelos quais a mesma categoria pode ser conhecida.

Definição: traz uma breve definição da categoria.

Exemplos: exemplos de informação pertencente à Categoria de Informação, a partir de uma variedade de disciplinas de base das coleções.

Notas: Abarca diferentes assuntos, incluindo se uma categoria de informação pode ser usada mais de uma vez ou não em um Grupo de Informação; se o conteúdo da categoria deve ser registrado em linguagem natural ou de acordo com 
um formato ou sintaxe definida; se um vocabulário controlado é recomendado para a Categoria de Informação.

Como é possível observar no Quadro 3, para o CIDOC, a responsabilidade é a finalidade da documentação que predomina em termos de associação, por ser vinculada a 18 grupos, seguida da função acesso - 17 grupos -, segurança - 15 grupos - e por último "arquivo histórico" - 11 campos. A vinculação da documentação ao controle das coleções parece ser reforçada por essa estrutura sugerida pelo CIDOC, que acaba justificando a informação sobre o objeto e a própria documentação à necessidade predominantemente administrativa ou de caráter operacional, como já abordado anteriormente.

Os grupos de informação, bem como as categorias que os compõem, refletem uma preocupação com o registro de informações acerca da materialidade dos objetos. A orientação sobre que tipo de informação deve ser coletado acerca da origem do objeto, seu estado de conservação, a sua presença física no espaço, a sua localização dentro da instituição explicitam uma atividade documentária que reforça uma preocupação com a identificação do suporte físico do item.

Nesse sentido, é possível entender que as Diretrizes propõem uma abordagem restrita sobre os objetos de museu, no que se refere à necessidade de coleta ou produção de informação dos contextos de uso e valores associados ao objeto. Um exemplo que ilustra claramente isso é a ausência de possibilidades, ou orientações sobre o registro de elementos da biografia do objeto, ou de seus antigos donos, bem como de saberes e fazeres a ele associados. Desse modo, tem-se um modelo que orienta o profissional a não se esquecer de registrar dados sobre as características físicas do objeto, sem dar maiores indícios do que poderia ser feito a respeito das facetas imateriais do mesmo.

Essa restrição em relação ao contexto ou à biografia do objeto - que é o que o insere na rede social do qual é vetor, e que lhe dá a base a partir da qual pode ser transformado em documento - se estende a outras situações, ao se pensar na heterogeneidade de elementos da realidade que podem ser transformados em "de museu". A arte contemporânea e todas as suas expressões - como a arte conceitual - e os elementos criados em universo eletrônico - de caráter artístico ou não também fazem parte da gama de possibilidades de tipos de objetos que podem estar 
presentes em um acervo de museu e cuja presença não parece ter sido amplamente prevista pelas Diretrizes.

Obviamente, na origem das Diretrizes não se pode afirmar o status sobre a discussão a respeito da documentação de elementos do universo digital, ou do patrimônio imaterial no âmbito do CIDOC. Mas, uma análise dos textos de apresentação dos boletins do CIDOC do mesmo período, ou até de períodos anteriores e posteriores, demonstra que o Comitê não estava tão apartado dessas discussões - por exemplo, os boletins do CIDOC dos anos de 1990, 1996, 1997, 1998, com os relatórios do Grupo de Trabalho de 'Multimídia', dedicado a discutir justamente as questões dos novos suportes digitais para armazenamento de imagens, arquivos de textos e de áudio.

Sendo assim, a organização dos grupos e categorias de informação reforça a definição apresentada no glossário da instituição. Vale lembrar, por último, que as Diretrizes do CIDOC se inserem dentro do raio de influência do entendimento tradicional acerca da documentação, corroborando, de forma coerente, com uma visão específica e tradicional sobre documentação e objeto. Ou seja, ao mesmo tempo, a publicação do CIDOC aponta novos caminhos ou questões sobre documentação, com a ênfase dada ao tratamento da informação sobre os objetos. Ela realiza tal iniciativa, a partir de bases que podem ser consideradas tradicionais, enfatizando o caráter administrativo e de controle desse fazer.

\subsection{Análise da SPECTRUM e das Diretrizes do CIDOC, frente às discussões sobre objeto de museu como documento e documentação em museus}

Neste ponto se realizará a análise da SPECTRUM e das Diretrizes do CIDOC frente ao quadro teórico delineado nos dois primeiros capítulos desta dissertação. Em vários momentos anteriores deste capítulo se ressaltou que a SPECTRUM e as Diretrizes são documentos que não se pretendem definitivos, ou mesmo referências teóricas sobre o assunto documentação. Como normas, se colocam mais como parâmetros do que uma prescrição absoluta sobre, respectivamente, procedimentos de gestão de acervos e categorias de informação sobre objetos. Apesar disso, é possível tecer considerações preliminares sobre os conceitos que fundamentam a estrutura de ambos os documentos à luz do objetivo central deste trabalho, que é 
discutir documentação em museus a partir do tripé teórico da Documentação, Ciência da Informação e Museologia.

O primeiro ponto a ser destacado é que a definição de documentação das Diretrizes e da SPECTRUM, conforme já salientado, ratifica um entendimento da documentação em museus ora como processo, ora como resultado do processo. Em resumo, é um entendimento que, mesmo com o intervalo temporal, remete ao início do uso do termo pela área de museus com Yvonne Oddon. Nesse quesito, o entendimento de documentação presente nos dois documentos difere daquele que é salientado aqui - ou seja, que busca compreender a documentação como um processo de trabalho, cujas bases teóricas advêm do encontro de várias disciplinas e que tem como um dos focos principais, não somente as questões de controle físico das coleções, mas a recuperação da informação para fins de comunicação com diferentes usuários dos museus.

Com isso não se pretende desconsiderar a pertinência das normas, mas chamar a atenção para que em outros contextos a discussão sobre documentação em museus pode ter outros horizontes. Ao se pensar novamente no contexto brasileiro, onde o fazer documental ganha contornos que evocam uma relação teórica com áreas como a Documentação, a Ciência da Informação e a Museologia - ainda que não tenham sido plenamente desenvolvidos - é necessário considerar a complexidade desse ato. Logo, a lógica operatória de todo o sistema de atividades deve ser permeada por essa abordagem integradora, que estabelece intelectualmente quais são os pressupostos a partir dos quais as etapas serão desenvolvidas.

Ao retomar a discussão sobre objeto de museus como documento, realizada no segundo capítulo desta dissertação, é possível compreender que os grupos da SPECTRUM e as categorias das Diretrizes do CIDOC, dedicados a descrever e representar as dimensões informativas de um objeto, podem ser complementados por outras orientações. Se um objeto, enquanto documento, é um ente transitório, cuja atribuição demanda constante ressignificação por parte de quem busca a informação e o documento, as categorias de informação que descrevem esse mesmo ente devem ser direcionadas para inseri-lo em panorama relacional.

Trata-se, portanto, de considerar o objeto a partir de uma matriz da informação (CERAVOLO; TÁLAMO, 2007) que estabelece os diferentes elos de conexão desse objeto com outros eventos, datas, lugares e personalidades que não 
somente aqueles diretamente relacionados a sua própria história dentro e fora do museu. Compreende-se, na abordagem proposta pelo presente trabalho, que tal configuração do trabalho documental consegue assegurar a exploração do objeto como documento, com toda a complexidade inerente a essa noção. E permite evitar a ênfase aos seus aspectos materiais e às informações sobre seu controle dentro do museu.

A partir do que foi discutido no terceiro capítulo, as duas normas são representantes de um entendimento anglo-saxão sobre documentação em museus, particularmente de países como Estados Unidos e aqueles que formam o Reino Unido. Nesses espaços, a documentação no universo dos museus tem ganhado cada vez mais limites que a restringem a um processo no âmbito de um fluxo maior, denominado política de gestão de acervo. Outra característica reforçada pelas duas normas é que a documentação em museus ainda é um tema abordado eminentemente discutido sob a égide da prática profissional. Conforme demonstrado pelo inventário presente naquele capítulo, muitas publicações reproduzem orientações consolidadas tradicionalmente no cotidiano das instituições. Cabe, portanto, aprofundar as reflexões de caráter teórico e metodológico.

$\mathrm{O}$ que se coloca com o entendimento adotado por este trabalho a respeito da documentação em museus é que, ao menos para o caso do contexto brasileiro, ela não se encontra restrita a uma etapa da gestão de acervos. Pelo contrário, pode funcionar como meio integrador de todas as etapas, a partir do momento que se compreende que ela é fundamental para a criação de padrões de representação da informação e interpretação dos acervos. Para tanto, cabe sempre a revisita à discussão sobre os usos do termo documentação e quais os significados e sentidos que o mesmo adquire. 


\section{CONCLUSÕES}

A pesquisa desenvolvida no âmbito desta dissertação aponta para a questão de que o tema da documentação em museus ainda demanda maior consolidação, principalmente nos âmbitos terminológico, metodológico e prático. Logo, é preciso reconhecer que noções como documentação, objeto e documento ainda se encontram em processo de institucionalização dentro da área de museus, demandando maior discussão e pesquisa interdisciplinar entre a Documentação, a Ciência da Informação e a Museologia.

A partir do objetivo geral da pesquisa, que foi analisar os usos associados aos termos documentação e objeto-documento na área de museus, de modo a comparar estudos realizados na teoria da Documentação, da Ciência da Informação e da Museologia com sua prática em museus, é possível levantar algumas conclusões. A maioria está discutida detalhadamente ao longo dos capítulos, mas podem ser retomadas agora para estruturar o fechamento desta pesquisa e apontar desdobramentos para possíveis estudos futuros.

A primeira conclusão é que, em termos genéricos, documentação é um termo que pode ser interpretado como específico de instituições que lidam com variados tipos e naturezas de acervo, e a Documentação é uma disciplina. São palavras homógrafas, mas com significados distintos, não marcados apenas pela opção deste trabalho: uma grafada com letra inicial minúscula; a outra, com maiúscula. Por isso e pelo desejo de caracterizar o uso do termo documentação especificamente na área de museus é que se opta pelo termo documentação em museus.

A documentação em museus é um termo utilizado para expressar um labor associado aos museus, como a própria designação indica. Durante muitos anos os termos usados para indicar tal labor foram muitos, quase sempre associados a uma ideia de registro da coleção de um museu, com finalidade de controle. Tal entendimento tem conhecido rupturas e modificações, expressas em diferentes formas de denominar esse fazer, mas conservando alguns aspectos, como a ênfase dada à ideia de um fazer da prática, focado no controle das coleções. Isso é particularmente detalhado no segundo capítulo.

Já por sua vez, a Documentação se coloca como uma área do saber que possui grandes contribuições teóricas para a reflexão sobre o que é documentar 
acervos em museus. Uma delas é a sua noção de documento enquanto algo que deve ser atribuído, processado e apropriado como tal, o que se iguala às características elencadas para a compreensão do que é um objeto no contexto do museu. Chega-se ao ponto em que as duas noções - documento e objeto - podem ser atribuídas a um mesmo elemento da realidade social. Em outras palavras, admite-se que um objeto pode ter também uma faceta documental, do mesmo modo que pode ter outras facetas, como a estética, a afetiva, etc.

Todavia, eis aqui uma situação colocada como hipótese a ser explorada em pesquisa de doutorado, por ultrapassar os limites da presente dissertação: se o objeto-documento é um termo que encerra a ideia de algo complexo, com múltiplos níveis de interpretação, é possível argumentar que sua apropriação teórica e seu processamento técnico demandam um trabalho constante de atualização de significados e sentidos. Apenas com essa dinâmica fluída é que este mesmo 'item' continuará a ser compreendido como objeto e como documento. Porém, quais serão as metodologias adequadas para processá-lo de forma a operacionalizar tal princípio teórico na prática cotidiana dos museus? Que significados devem ser atribuídos à documentação para englobar essas ideias de dinâmica e renovação de significados?

Conforme apresentado no segundo capítulo, vale a ressalva que as práticas e metodologias da Documentação - como a Análise Documentária, por exemplo dependem ainda de adaptações e maior aproximação com o universo do tratamento documentário dos acervos de natureza museológica. Comparativamente, no que se refere à busca de subsídios na Museologia, as práticas ainda são bastante pautadas em questões de controle do acervo, conforme demonstra parte da literatura existente sobre o tema e que está trabalhada no terceiro capítulo. A literatura que discute teoria e prática é ainda pouca e merece ganhar maior amplitude e reconhecimento.

Em outras palavras, cabe ainda a reflexão sobre o como fazer uso do repertório conceitual e metodológico da Documentação, da Ciência da Informação e da Museologia no universo dos museus, de modo a abarcar todos os aspectos, materiais e imateriais, dos acervos que costumam ser preservados por esse tipo de instituição, a partir de uma perspectiva interdisciplinar. Teoria e prática devem ser mais integradas, permitindo a operacionalização de conceitos, experiências e hipóteses teóricas, de modo a explorar as tensões e desafios advindos do encontro desses dois âmbitos. É nisso que se resume a primeira conclusão derivada da 
execução do objetivo geral da pesquisa, trabalhado particularmente no segundo capítulo desta dissertação.

A próxima conclusão é que, subjacente às questões metodológicas que se colocam como desafios para o aprimoramento do entendimento do que é documentação em museus e do que é o objeto-documento nos museus, é importante salientar que as diferenças terminológicas continuarão a existir. Diz-se isso tendo por base que o significado de documentação e documento em um determinado espaço e tempo, para um determinado grupo de profissionais ou teóricos da área de museus, pode não significar a mesma coisa para outro grupo, de outro, ou do mesmo, espaço e tempo. O terceiro capítulo esclareceu as especificidades das variações discursivas em torno dos termos documentação e documento, devido ao levantamento bibliográfico realizado. Nesse caso, foi possível realizar um dos objetivos específicos de mapear o emprego de tais termos na literatura selecionada para pesquisa.

O levantamento, por mais que não se pretendesse completo e absoluto, permite a apreensão sistematizada de nuances da discussão sobre os usos dos termos estudados, particularmente documentação. Por exemplo, é possível ter maior clareza sobre o fato de que, quando um autor britânico usa o termo museum documentation, não necessariamente está falando do que se entende usualmente no Brasil por documentação museológica. Isso, porque há diferenças linguísticas e de configuração da área de museus nos dois países que, em uma primeira análise, poderiam indicar significados muito próximos ou idênticos.

Permite também a compreensão de que, no caso da literatura produzida em países como o Reino Unido e os Estados Unidos, existe uma forte ideia de que o termo documentação representa um fazer prático, restringindo-se às tarefas operacionais de controle da coleção para fins de uma boa administração do patrimônio pelo museu.

Essa convergência não significa a inexistência de indagações de fundo teórico sobre o assunto nesses contextos. Esse seria um pressuposto que, além de superficial, desconsideraria a interpenetração de influências nos processos de produção de conhecimento. Portanto, é possível afirmar que existe uma tendência anglo-saxônica sobre documentação, marcada por um viés pragmático, mas que a ele não se resume. E, conforme explicou Marín Torres (2002), a essa perspectiva pode se dar o nome de gestão da informação, ou ainda gestão de coleções, cujo 
foco é o resultado imediato do trabalho da documentação - ou seja, a difusão da informação, a partir da implantação de procedimentos que permitem o controle das peças.

No caso de países como Espanha e Brasil, a preocupação com os aspectos práticos focados no controle da coleção também existe. Ratifica-se por vezes o significado de documentação como um termo que designa um conjunto de atividades marcadas por tipos específicos de ações e documentos. Por outro lado, a literatura de ambos os países possui autores que usam o termo documentação de forma diferenciada, e não raro enveredam por um caminho mais próximo da Ciência da Informação. Nesses casos, o termo documentação se insere em discursos que falam não somente em controle da coleção, mas, sobretudo, em difusão dos acervos para o público interno e externo das instituições. A ideia de documentação, em museus, se associa a um fazer social, cuja comunicação de sentidos é um ponto norteador para a discussão.

A expressão documentação museológica é a dominante no Brasil. Em uma primeira interpretação, seria possível entendê-la como um saber específico da Museologia, a ela vinculado e dela derivado. Ademais, o uso do adjetivo museológica também indica que a Museologia dá uma série de características a esse saber, formando assim um conjunto comum de traços constitutivos que a diferenciariam de outras formas e definições de documentação existentes em outras áreas.

Se a Museologia é entendida como um campo disciplinar autônomo, que se vale da interdisciplinaridade para construção de seus quadros teóricos, torna-se premente, então, o detalhamento dos fundamentos - existentes dentro desses quadros teóricos - que fundamentam a especificidade da documentação museológica. Contudo, na maior parte da literatura nacional produzida sobre o tema, esse entendimento da documentação museológica também não é consensual. 0 assunto demanda maior aprofundamento no sentido de refletir com maior profundidade sobre o fazer documental, seja como conceito ou enquanto atividade, seja pela Museologia, ou pelas disciplinas que com ela fazem fronteira, como a Documentação e a Ciência da Informação.

Portanto, é necessário admitir a relatividade dos significados das palavras: uma definição categórica sobre o que é documentação no contexto dos museus não faria sentido. Isso não quer dizer que não se possa fazer discussões conceituais ou 
práticas sobre o assunto, cotejando textos de diferentes autores, oriundos de espaços tão distintos quanto o Reino Unido, Estados Unidos, Espanha e Brasil. Mas sim que, para tal discussão, é necessário que se pondere sobre as especificidades linguísticas e as características da área de museus de cada lugar. Desse modo, os contornos da polissemia em torno dos termos documentação e objeto-documento, no contexto dos museus, podem se tornar cada vez mais reconhecidos. Em outras palavras, os autores e profissionais que lidam com as questões documentárias em museus deverão produzir maiores avanços em questões terminológicas a partir da consciência do seu próprio lugar de fala.

Tal conclusão - de que apesar das diferenças, é possível construir metodologias em conjunto para intercâmbio teórico e prático em torno dos termos documentação e objeto-documento - é especialmente reforçada pela análise das normas do CIDOC e da SPECTRUM. O estudo de ambas é realizado a partir de categorias de análise, construídas para criar parâmetros de comparabilidade entre elas, tais como ano de publicação, origem dos editores, definições utilizadas, estrutura textual, entre outras.

O estudo indica que elas perpetuam a ideia de documentação como um termo que designa um processo em que o controle da coleção é fundamental, podendo ser também o resultado do processo, os documentos gerados a partir dele. No caso dos objetos, eles são compreendidos como peças que estão no museu, não havendo discussão se são ou não documentos. Desse modo, elas se mantêm alinhadas com o discurso predominante do contexto anglo-saxão sobre o assunto, ou seja, refletem a tendência pragmática. Isso permite compreender que a SPECTRUM e as Diretrizes do CIDOC, apesar de propostos como modelos internacionais, refletem, principalmente no tangente às definições utilizadas em seus glossários, uma perspectiva sobre o assunto que é anglo-saxônica.

Isso, entretanto, não equivale a dizer que as normas não sejam essenciais para a área de museus, tendo em vista sua abrangência e anos de aderência pelos profissionais que delas fazem uso ao redor do mundo. Por exemplo, seria perfeitamente possível e desejável imaginar o uso, no Brasil, das Diretrizes do CIDOC e da SPECTRUM - menos como soluções ou propostas acabadas sobre documentação, e mais como pontos de partida para a organização de boas práticas, realização de estudos de caso e de discussões críticas e produtivas sobre as diferenças das tendências entre os conceitos e práticas do CIDOC, do Reino Unido 
e Brasil. Um desdobramento de tal raciocínio é que a consciência em torno dos limites de tais normas demanda que seu uso deva ser adaptado às realidades locais, em conjunto com outras normas produzidas dentro dos próprios países, ou pelas instituições.

Ainda é possível pensar no uso de outras normas que se complementam às Diretrizes do CIDOC e à própria SPECTRUM, que colaboram para lançar novas perspectivas sobre os significados de documentar objetos em museus, a partir de questões de terminologia e significado de conceitos. Um exemplo é o CIDOC Conceptual Reference Model - CIDOC CRM -, uma ontologia criada pelo Comitê Internacional de Documentação do ICOM, que descreve os conceitos implícitos e explícitos utilizados na documentação de patrimônio cultural. O CIDOC CRM se enquadra como uma referência ambientada no escopo Web 3.0, a geração da internet que possui alta ênfase em protocolos para estruturação do significado dos termos que descrevem conteúdos informacionais, com objetivo de facilitar sua posterior recuperação pelos usuários.

Pode-se concluir que o CIDOC CRM coloca em primeiro plano a relevância da contextualização do conteúdo registrado em banco de dados, pensando que não importa só o de/para dos campos que descrevem um documento, mas, sobretudo do conteúdo registrado. A diretriz traz também uma segunda questão que é a abordagem ou lógica (multi)relacional sobre um acervo. $E$ esse último ponto é extremamente importante para abrir caminhos para novas discussões sobre a documentação em museus e sobre os objetos-documentos.

Dilui-se, com o CIDOC CRM, a proposta mais tradicional de normas que propõem somente a descrição sobre o objeto e sua história particular - Quem fez? Quando fez? Porquê fez? Como fez? Etc. -, e amplia-se a abordagem da documentação e de objeto como processos, em que é possível realizar inúmeras associações entre as entidades - objetos, pessoas, lugares - e suas propriedades, físicas, simbólicas, etc. Exemplo: por meio da aplicação dos conceitos do CIDOC CRM, é possível saber se um objeto se relaciona com outro diferente, porque talvez tenham vindo da mesma região e foram produzidos em uma mesma época. Ou relacionar as obras de um determinado pintor como influências para um conjunto, ou uma escola artística, etc.

Desse modo, o uso conjugado dos conceitos do CIDOC CRM com as Diretrizes do CIDOC - que trazem uma proposta mínima de dados a serem 
produzidos sobre diferentes camadas de informação do objeto - e da SPECTRUM que traz a organização dos procedimentos de gestão de um acervo e também uma proposta de dados a serem produzidos -, abre um caminho complexo, com várias chaves de conexão a serem aplicadas no tratamento documentário dos acervos. Ressalta-se, mais uma vez, que todas as referências citadas refletem a tendência anglo-saxônica, demandando atenção, crítica e consciência em torno dos conceitos empregados em relação à realidade vivida por cada interessado em adotá-los.

Vale salientar que esta análise permite compreender que as questões aqui apresentadas não são propriamente novas, porém, é novo o foco que os pesquisadores têm dado a elas. Os problemas comentados aqui também não são novos, nova é a escala e a importância dada a eles, frente a uma realidade que exige de profissionais e teóricos de museus outra forma de lidar com questões documentárias e suas implicações e rebatimentos no cotidiano. Fica clara, sobretudo, a necessidade de se conhecer os limites dos termos, a ausência de alguns deles, as tensões inerentes ao seu uso em cada contexto e tendência identificada.

Por fim, fica clara também que a preocupação com as questões terminológicas não advém somente da necessidade dos pesquisadores e profissionais da área de museus de entenderem melhor os discursos uns dos outros, mas da própria necessidade de dar outros sentidos para a própria documentação em museus e para os acervos. Hoje, há maior consciência de que o museu tem públicos multifacetados, ávidos pela interação e dinâmicas informacionais, e com variadas opções de diversão e lazer. Esses públicos, no entanto, podem se engajar fortemente nas políticas de patrimônio cultural se sentirem que o museu faz parte de suas vidas.

Os museus se veem, hoje, diante da oportunidade de se tornarem também serviços de informação e requerem, para isso, uma documentação em museus que coopere fortemente para a oferta de novos sentidos e memórias a partir dos acervos. Espera-se que este trabalho possa ter contribuído, ainda que inicialmente, para tal movimento. 


\section{REFERÊNCIAS BIBLIOGRÁFICAS}

ALEXANDER, Edward P. What is a museum? In: Museums in motion: an introduction to the History and Functions of Museums. Nashville: American Association for State and Local History, 1979. p. 5-15.

ALIANÇA AMERICANA DE MUSEUS. American Alliance of Museums - About Us. Disponível em: <http://www.aam-us.org/about-us>. Acesso em: 16 jan. 2014.

ALIANÇA AMERICANA DE MUSEUS. Is a postgraduate museum studies course right for you? Museums Association. Disponivel em: <http://www.museumsassociation.org/careers/8326>. Acesso em 15 jan. 2014.

BACA, Murtha. Thoughts on cultural heritage in the 21st. century: using data and the Web to connect users and collections. CIDOC Newsletter, n. 1, p. 3-6, 2010. Disponível em: <http://network.icom.museum/cidoc/archives/past-newsletters/>. Acesso em: 24 fev. 2013.

BAKHTIN, Mikhail. Marxismo e filosofia da linguagem: problemas fundamentais do método sociológico na ciência da linguagem. 10 . ed. São Paulo: HUCITEC/Annablume, 2004. 203 p.

BARROSO, Gustavo. Introdução à Técnica de Museus. Rio de Janeiro: Gráfica Olímpica, 1951. v. 2.

BELLAIGUE, Mathilde. Memória, Espaço, Tempo, Poder. Revista Eletrônica Museologia e Patrimônio, v. 2, n. 2, p. 87-90, jul./dez. 2009. Disponível em: $<$ http://revistamuseologiaepatrimonio.mast.br/index.php/ppgpmus/article/viewFile/78/ 98>. Acesso em: 10 mai. 2012.

BITTENCOURT, José Neves. A pesquisa como cultura institucional: objetos, política de aquisição e identidades nos museus brasileiros. In: SANTOS, Claudia Penha dos; GRANATO, Marcos (Orgs.). Museu: instituição de pesquisa. Rio de Janeiro: MAST, p. 37-49, 2005. (MAST Colloquia; 7).

BOTTALLO, Marilúcia. A Documentação dos Acervos Contemporâneos: Critérios e Metodologias - Os Sentidos do Patrimônio e do Colecionismo; Métodos de Registro; Transitoriedade e Permanência. In: ENCONTRO CONSERVAR PARA NÃO RESTAURAR, 2000, São Paulo. Anais do Encontro Conservar para Não Restaurar. São Paulo: ITAÚ Cultural, 2000. Mesa-Redonda. Disponível em: $<$ http://www.itaucultural.org.br/conservar_nao_restaurar/ficha.htm>. Acesso em: 01 dez. 2012.

A Gestão Documental do Patrimônio Arqueológico e Etnográfico. Revista do Museu de Arqueologia e Etnologia da USP, São Paulo, n. 6, p. 287-292, 1996.

BRASIL. Decreto Federal $n^{0}$ 8.124, de 17 de outubro de 2013. Regulamenta dispositivos da Lei $n^{\circ} 11.904$, de 14 de janeiro de 2009, que institui o Estatuto de Museus, e da Lei $n^{\circ}$ 11.906, de 20 de janeiro de 2009, que cria o Instituto Brasileiro 
de Museus - IBRAM. Disponível em: <http://www.planalto.gov.br/ccivil_03/_Ato20112014/2013/Decreto/D8124.htm>. Acesso em: 25 jun.2013.

BRASIL. Congresso Nacional. Lei no 11.904, de 14 de janeiro de 2009. Institui o Estatuto de Museus e dá outras providências. Disponível em: http://www.planalto.gov.br/ccivil_03/_Ato2007-2010/2009/Lei/L11904.htm. Acesso em: 25 jun.2013.

BRASIL. Congresso Nacional. Lei $n^{\circ}$ 7.287, de 18 de dezembro de 1984. Dispõe sobre a Regulamentação da Profissão de Museólogo.Disponível em: <http://www.planalto.gov.br/ccivil_03/Leis/L7287.htm>. Acesso em: 25 jun.2013.

BRIET, Suzanne. What is Documentation?. English translation of the Classic French Text. Trad. and edit. Ronald E. Day, Laurent Martinet, Hermina G.B. Anghelescu. EUA: Scarecrow Press, 2006. 72 p.

BUCK, Rebecca A.; GILMORE, Jean Allman (Eds.). Museum Registration Methods. 5. ed. EUA: American Association of Museums Press, 2010. 516 p.

BUCKLAND, Michael K. What is "document"? Journal of the American Society for Information Science, v. 48, n. 9, p. 804-809, 1997. Information as a thing. v. 42, n. 5, p. 351-360, 1991.

CABALLERO ZOREDA, Luiz. La Documentación Museológica. Boletín de la ANABAD, Espanha, v. 38, n. 4, p. 455-495, 1988. Disponível em:

< http://dialnet.unirioja.es/servlet/articulo?codigo=798916 >. Acesso em: 10 fev. 2013.

CAMARGO-MORO, Fernanda de. Museu: Aquisição/Documentação. Rio de Janeiro: Livraria Eça Editora, 1986. 320 p. (Coleção Eleutherias).

CÂNDIDO, Manuelina Maria Duarte. As ondas do pensamento museológico: balanço sobre a produção brasileira. In: BRUNO, Maria Cristina Oliveira; NEVES, Kátia Regina Felipini (Orgs.). Museus como agentes de mudança social e desenvolvimento: propostas e reflexões museológicas. São Cristóvão: Museu de Arqueologia de Xingó, 2008.

CÂNDIDO, Maria Inês. Documentação Museológica. In: Secretaria de Estado de Cultura de Minas Gerais. Caderno de Diretrizes Museológicas 1. 2. ed. Brasília: Ministério da Cultura/IPHAN/DEMU; Belo Horizonte: Secretaria de Estado da Cultura/Superintendência de Museus, 2006. p. 31-90.

CAPURRO, Rafael. Epistemologia e Ciência da Informação. In: V ENANCIB ENCONTRO NACIONAL DE PESQUISA EM CIÊNCIA DA INFORMAÇÃO, 2003, Belo Horizonte. Anais do V Enancib. Belo Horizonte: Escola de Ciência da Informação da UFMG, 2003. Disponível em: <www.capurro.de/enancib_p.htm>. Acesso em: 14 jun. 2013. 
CARRETERO PÉREZ, Andrés et al. Normalización documental de museos: elementos para una aplicación informática de gestión museográfica. España: Ministerio de Educación y Cultura, 1998. 550 p.

CASTRO, Ana Lúcia Siaines de. O Museu do sagrado ao segredo. Rio de Janeiro: Editora Revan, 2009. 196 p.

CERAVOLO, Suely Moraes. Apontamentos sobre a Documentação de Museus. In: OBSERVATÓRIO DA MUSEOLOGIA BAIANA. Blogue. Postado em: 25 dez. 2012. Disponível em: <http://observatoriodamuseologiabaiana.blogspot.com.br>. Acesso em: 30 abr. 2013.

Tecendo interfaces teóricas e metodológicas por sobre o conceito museologia: o exercício de uma tese. In: SANTOS, Claudia Penha dos; GRANATO, Marcos; LOUREIRO, Maria Lucia de N. M. (Orgs.). Museu e Museologia: Interfaces e Perspectivas, Rio de Janeiro: MAST, 2009. p. 7-24. (MAST Colloquia; 11).

. Delineamentos para uma Teoria da Museologia. Anais Do Museu Paulista: história e cultura material. São Paulo: v. 12, p. 237-268, jan./dez. 2004.

Proposta de Sistema de Informação Documentária para Museus (SIDM): a Organização da Informação para o Museu de Anatomia Veterinária da Faculdade de Medicina Veterinária e Zootecnia da Universidade da São Paulo. São Paulo, 1998. 122 p. Dissertação (Mestrado em Ciência da Informação) - Escola de Comunicações e Artes, USP, São Paulo, 1998.

; TÁLAMO, Maria de Fátima Gonçalves Moreira. Os museus e a representação do conhecimento: uma retrospectiva sobre a documentação em museus e o processamento da informação. In: VIII ENANCIB - ENCONTRO NACIONAL DE PESQUISA EM CIÊNCIA DA INFORMAÇÃO, 2007, Salvador. Anais do VIII Enancib, Salvador: PPGCI/UFBA, 2007. s/p. Disponível em: <http://www.enancib.ppgci.ufba.br>. Acesso em: 30 abr. 2010.

Tratamento e Organização de informações documentárias em museus. Revista do Museu de Arqueologia e Etnologia da USP, São Paulo, n. 10, p. 241-253, 2000.

CHOAY, Françoise. A alegoria do patrimônio. São Paulo: Estação Liberdade/Editora UNESP, 2001. 282 p.

COLLECTIONS TRUST. Glossary for SPECTRUM 4.0. Dawnson, Alex (Ed.). Reino Unido, 2011a. Disponível em: <http://www.collectionstrust.org.uk/spectrum/glossaryfor-spectrum-4-0>. Acesso em: 27 jun. 2014.

COLLECTIONS TRUST. The SPECTRUM Standard 4.0. 2011b. Disponível em: <http://www.collectionstrust.org.uk/spectrum>. Acesso em: 15 jun. 2014.

COLLECTIONS TRUST. OpenCulture 2014: Bigger than ever! Londres, 2014. Disponível em: <http://www.collectionstrust.org.uk/openculture2014>. Acesso em: 27 jun.2014. 
COMITÊ INTERNACIONAL DE DOCUMENTAÇÃO - ICOM (CIDOC-ICOM). International Guidelines for Museum Object Information: The CIDOC Information Categories. International Council of Museums. 1995. Disponivel em: <http://network.icom.museum/cidoc/resources/cidoc-standards-guidelines>. Acesso em: 12 abr. 2014.

COMITÊ INTERNACIONAL DE DOCUMENTAÇÃO - ICOM (CIDOC-ICOM). Declaração de Princípios de Documentação em Museus e Diretrizes Internacionais de Informação sobre Objetos de Museus: Categorias de Informação do Comitê Internacional de Documentação. Tradução de Marilúcia Bottallo. São Paulo: Secretaria de Estado da Cultura de São Paulo; Pinacoteca do Estado de São Paulo, 2014. 76 p.

COMITÉ INTERNACIONAL DE DOCUMENTAÇÃO - ICOM (CIDOC-ICOM). 1996 Newsletter. CIDOC Newsletter, v. 7, ago. 1996. Disponível em: <http://network.icom.museum/cidoc/archives/past-newsletters/1996-newsletter/>. Acesso em: 23 mai. 2013.

COMITÊ INTERNACIONAL DE DOCUMENTAÇÃO - ICOM (CIDOC-ICOM). What is LIDO - Lightweight Information Describing Objects. Disponível em: <http://network.icom.museum/cidoc/working-groups/data-harvesting-andinterchange/what-is-lido>. Acesso em: 03 mar. 2013.

CONSELHO Internacional de Museus (ICOM). Código de Ética do ICOM para Museus: versão lusófona. São Paulo: Secretaria de Estado da Cultura de São Paulo, 2009. 31 p.

CONSELHO INTERNACIONAL DE MUSEUS (ICOM). The CIDOC Conceptual Reference Model. Disponível em: <http://www.cidoc-crm.org>. Acesso em: 15 out. 2012.

CROFTS, Nick. A word from the Chair. In: CIDOC Newsletter, 2011. p. 2-5. Disponível em: <http://network.icom.museum/cidoc/archives/past-newsletters/2011newsletter/>. Acesso em: 20 mai. 2013.

CURY, Marília Xavier. Exposição: concepção, montagem e avaliação. São Paulo: Annablume, 2005. $160 \mathrm{p}$.

DESVALLÉES, André; MAIRESSE, François (Eds.). Key Concepts of Museology. ICOM, Armand Colin, 2010. $90 \mathrm{p}$. Translated from the French version by Suzanne Nash. Disponível em: <http://icom.museum/professional-standards/key-concepts-ofmuseology/>. Acesso em: 14 mar. 2012.

DIBAM - DIREÇÃO DE BIBLIOTECAS, ARQUIVOS E MUSEUS. Centro de Documentación de Bienes Patrimoniales. Chile. Disponível em: <http://www.cdbp.cl>. Acesso em: 05 jan. 2013.

DOBEDEI, Vera Lucia Doyle. Tesauro: linguagem de representação da memória documentária. Niterói: Intertexto; Rio de Janeiro: Editora Interciência, 2002. 120 p. 
FERREZ, Helena Dodd. Documentação museológica: teoria para uma boa prática. In: IV FÓRUM NORDESTINO DE MUSEUS, 1991, Recife. Anais do IV Fórum Nordestino de Museus. Recife: IBPC/Fundação Joaquim Nabuco, 1991. Disponível em: < http://pt.scribd.com/doc/38689114/Documentacao-Museologica-Helena-DoddFerrez>. Acesso em: 10 mar. 2010.

; BIANCHINI, Maria Helena S. Thesaurus para acervos museológicos. Rio de Janeiro: Fundação Pró-Memória, v. 2, 1987.

; PEIXOTO, Maria Elizabete Santos. Manual de catalogação: pintura, escultura, desenho, gravura. Rio de Janeiro: Museu Nacional de Belas Artes, 1995. $67 \mathrm{p}$.

FONSECA, Maria Cecília Londres. Para além da pedra e cal: por uma concepção ampla de patrimônio cultural. In: ABREU, Regina; CHAGAS, Mario (Orgs.). Memória e patrimônio: ensaios contemporâneos. Rio de Janeiro: DP\&A, FAPERJ e UNI-RIO, 2003. p. $56-77$.

FROHMANN, Bernd. O caráter social, material e público da Informação. In: FUJITA, Mariângela Spotti Lopes; MARTELETO, Regina Maria; LARA, Marilda Lopes Ginez de (Orgs.). A dimensão epistemológica da Ciência da Informação e suas interfaces técnicas, políticas e institucionais nos processos de produção, acesso e disseminação da Informação. São Paulo: Cultura Acadêmica Editora; Marília: FUNDEPE Editora, 2008. p. 13-36.

GARCIA CANCLÍNI, Néstor. A globalização imaginada. São Paulo: Editora lluminuras, 2003. 223 p.

GETTY INSTITUTE. About the AAT - Art \& Architecture Thesaurus. Getty Research Institute. Disponível em: <http://www.getty.edu/research/tools/vocabularies/aat/about.html>. Acesso em: 11 fev. 2013.

GOVERNO DO CANADÁ. Canadian Heritage Information Network. Canadá. Disponível em: <http://www.rcip-chin.gc.ca/apropos-about/histoire-history/indexeng.jsp>. Acesso em: 16 mar. 2014.

GRANT, Alice. Museums, information and collaboration: why a single standard is not enough. In: CONSELHO Internacional de Museus. Study Series - International Committee for Documentation, $n^{03}, 1996$. Disponível em: http://archives.icom.museum/study_series_pdf/3_ICOM-CIDOC.pdf. Acesso em: 29 jul.2014.

GRUPO BSI. O que é uma norma? British Standards Institution. Brasil. Disponível em: <http://www.bsibrasil.com.br/publicacoes/sobre_normas/normas/>. Acesso em: 27 set. 2013. 
GUARNIERI, Waldisa Russio Camargo. Conceito de cultura e sua inter-relação com o patrimônio cultural e a preservação. Cadernos Museológicos, Rio de Janeiro: IPHAN/Pró Memória, n. 3, p. 7-12, 1990.

GUTIÉRREZ USILLOS, Andrés. Museología y documentación: criterios para la definición de un proyecto de documentación en museos. Espanha: Editora Trea, 2010. 206 p.

HERNÁNDEZ-HERNÁNDEZ, Francisca. Manual de Museología. Madrid: Editorial Síntesis, 1998. 319 p.

HOLM, Stuart A. Facts and Artifacts: how to document a museum collection. UK: Museum Documentation Association, 1991. 40 p.

LARA FILHO, Durval de. Modos do museu: entre a arte e seus públicos. São Paulo, 2013. 223 p. Tese (Doutorado em Ciência da Informação) - Escola de Comunicações e Artes, Universidade de São Paulo, São Paulo, 2013. Disponível em: $\quad$ <http://www.teses.usp.br/teses/disponiveis/27/27151/tde-23082013-111500/>. Acesso em: 15 mar. 2014.

LARA, Marilda Lopes Ginez de. Relações entre Ciência da Informação e Museologia. In: SÁ, Aluane de; MONTEFUSCO, Hitalo; BOITA, Tony (Orgs.). Anais do IV Encontro Nacional de Estudantes de Museologia - Museologia e Interdisciplinaridade. Goiânia. Digital Books Editora, 2012. p. 26-35. Disponível em: <https://docs.google.com/file/d/0B8etMAdaKSnfonJyRjk2aUF0TU0/edit?pli=1> Acesso em: 27 dez. 2012.

; ORTEGA, Cristina Dotta. A noção de documento: de Otlet aos dias de hoje. In: IX CONGRESSO ISKO - ESPAÑA, mar. 2009, Valência. Nuevas perspectivas para la difusión y organización del conocimiento - Actas del Congresso, 2009, Valencia: Universidad Politécnica de Valencia, Servicio de Publicaciones, v. 1. p. 528-544, 2009.

Disponível

em:

$<$ http://dialnet.unirioja.es/servlet/libro?codigo=356731\#volumen45548>. Acesso em: 15 jan. 2012. Informação In: SILVA, Fabiano Couto Correa da: SALES, Rodrigo de (Orgs). Cenários da organização do conhecimento: linguagens documentárias em cena. Brasília: Thesaurus, 2011. p. 17-41.

LE COADIC, Yves François. A Ciência da Informação. 2. ed. Brasília: Briquet de Lemos, 2004. $124 \mathrm{p}$.

LIGHT, Robert B.; ROBERTS, D. Andrew; STEWART, Jennifer D. Museum Documentation Systems: developments and applications. London: Butterworths, 1986. 332 p.

LOPES, Maria Margaret. O Brasil descobre a pesquisa científica: os museus e as ciências naturais no século XIX. São Paulo: Aderaldo e Rotschild; Brasília: Editora UnB, 2009. 369 p. 
LOUREIRO, José Mauro Matheus. A Documentação e suas diversas abordagens: esboço acerca da unidade museológica. In: GRANATO, Marcus; SANTOS, Claudia Penha dos; LOUREIRO, Maria Lúcia Niemeyer Matheus (Orgs.). Documentação em Museus. Rio de Janeiro: MAST, p. 24-32, 2008. (MAST Colloquia; 10).

LUHMANN, Niklas. Soziale Systeme. Suhrkamp, Frankfurt am Main: Suhrkamp, 1987.

LUND, Niels Windfeld. Document theory. Annual Review of Information Science and Technology, v. 43, n. 1, p. 1-55, 2009. Disponível em: $<$ http://onlinelibrary.wiley.com/doi/10.1002/aris.2009.1440430116/full>. Acesso em: 13 abr. 2012.

MARÍN TORRES, María Teresa. Historia de la documentación museológica: la gestión de la memoria artística. Espanha: Editora Trea, 2002. 387 p.

MATOS, Alexandre Manuel Ribeiro. Os sistemas de informação na gestão de colecções museológicas: contribuições para a certificação de museus. Porto, 2007. 204 p. Dissertação (Mestrado em Museologia) - Faculdade de Letras, Universidade do Porto, 2007. Disponível em: <http://repositorioaberto.up.pt/bitstream/10216/13038/2/Tesemestsistemasdeinformacao000069301.pd f>. Acesso em: 19 abr. 2013.

MATOS, Alexandre Manuel Ribeiro. SPECTRUM: uma norma de gestão de coleções para os museus portugueses. Porto, 2012. 366 p. Tese (Doutoramento em Museologia) - Faculdade de Letras, Universidade do Porto, 2012. Disponível em: <http://repositorio-aberto.up.pt/handle/10216/67304>. Acesso em: 29 jul. 2014.

MCKENNA, Gordon; DE LOOF, Chris. Digitisation: standards landscape for european museums, archives, libraries. ATHENA WP3 - Working group: Identifying Standards and Developing Recomendations. Roma: ATHENA, 2009. Disponível em: $<$ http://www.athenaeurope.org/index.php?en/112/news/20/athena-bookletdigitisation-standards-landscape-for-european-museums-archives-libraries $>$. Acesso em: 10 jun. 2013.

MENESES, Ulpiano Teixeira Bezerra de. Do teatro da memória ao laboratório da história: a exposição museológica e o conhecimento histórico. Anais do Museu Paulista: história e cultura material. São Paulo. v. 2, p. 9-42, jan./dez. 1994.

MENSCH, Peter Van. The object as data carrier. In: Towards a methodology of Museology. Zagreb, 1992. Tese (Doutorado em Museologia) Universidade de Zagreb, $1992 . \quad$ Disponível em: $<$ http://www.muuseum.ee/et/erialane_areng/museoloogiaalane_ki/ingliskeelne_kirjan d/p_van_mensch_towar/mensch12>.Consulta em: 18 jan. $201 \overline{2}$.

El objeto como portador de datos. Cuadernos de Museología, Lima: Museu de Arte Popular, p. 53 - 62, 1989. 
MINISTÉRIO DA CULTURA DA ARGENTINA. Servicio Nacional de Inventarios de Patrimonio (SENIP). Ministerio de Cultura. Presidencia de La Nación. Argentina. Disponível em: <http://www.cultura.gob.ar/acciones/servicio-nacional-de-inventariosde-patrimonio-senip/>. Acesso em: 24 mar. 2013.

MINISTÉRIO DA CULTURA DA COLÔMBIA. Ministerio de Cultura de Colombia. Colômbia. Disponível em: <http://www.mincultura.gov.co>. Acesso em: 10 ago. 2011.

MINISTÉRIO DA EDUCAÇÃO, CULTURA E ESPORTE DA ESPANHA. Formación de postgrado en materia de Museos. Gobierno de España. Espanha. Disponível em: <http://www.mcu.es/museos/CE/RecProf/Formacion.html>. Acesso em 15 jan. 2014.

MINISTÉRIO DA EDUCAÇÃO, CULTURA E ESPORTE DA ESPANHA. Red Digital de Colecciones de Museos de España. Gobierno de España. Espanha. Disponível em: <http://ceres.mcu.es/pages/SimpleSearch?index=true>. Acesso em: 15 jan. 2014.

MURPHY, Bernyce L. La definición del museo: de una referencia para el especialista a un papel social. Notícias del ICOM, n. 2, p. 3, 2004.

NASCIMENTO, Rosana Andrade do. Documentação Museológica e Comunicação. Cadernos de Museologia, Portugal, v. 3, p. 33-43, 1994.

NOVAES, Lourdes Rego. Da organização do patrimônio museológico: refletindo sobre documentação museográfica. In: SECRETARIA MUNICIPAL DA CULTURA DE PORTO ALEGRE. Museologia social. Porto Alegre: Unidade Editorial/Secretaria Municipal de Cultura, 2000. p. 43-66.

ODDON, Yvonne. Elements of Museum Documentation: Eléments De Documentation Muséographique. In: R_. Report on a museographical mission in Jos (Nigeria): February 26 - April 8, 1968. 85 p. Nigeria: Jos Museum. 1968. Centro de formação para Técnicos de Museus. Disponível em: $<$ http://unesdoc.unesco.org/ulis/cgibin/ExtractPDF.pl?catno=158018\&look=default\&ll =1\&display=1\&lang=mb\&from=\&to= $\geq$. Acesso em: 25 fev. 2013.

OLCINA, Paulette. The Development and Coordination of Museum Documentation by International Agencies. In: LIGHT, Robert B.; ROBERTS, D. Andrew; STEWART, Jennifer D. Museum Documentation Systems: developments and applications. London: Butterworths, 1986. p. 307-314.

The UNESCO-ICOM Centre: documentation in the service of the museologist. Museum, Paris, v. 23, n. 1, p. 61-62, 1970.

OLIVEIRA, Paulo de Salles. Caminhos de construção da pesquisa em ciências humanas. In: (Org.). Metodologia das Ciências Humanas. 2. ed. São Paulo: Editora UNESP/HUCITEC, 2001. p. 17-26. 
OROZ, Joel J. The American Compromise, 1850-1870: the synteshis of popular education and professionalism. In: Curators and culture: the museum movement in America, 1740-1870. Alabama: The University of Alabama Press, 2002. p. 181-237.

ORTEGA, Cristina Dotta. A Documentação como uma das origens da Ciência da Informação e base fértil para sua fundamentação. Brazilian Journal of Information Science, v. 3, n. 1, p. 3-35, jan./jun. 2009. Disponível em: $<$ http://www2.marilia.unesp.br/revistas/index.php/bjis/article/viewFile/48/263>.

Acesso em: 24 abr. 2011.

ORNA, Elizabeth. Information policies for museums. United Kindom: Museum Documentation Association, 1987, 30p.

OTLET, Paul. Documentos e Documentação. Tradução: Hagar Espanha Gomes. Paris, 1937. Introdução aos trabalhos do Congresso Mundial da Documentação Universal, realizado em Paris, 1937. s/p. Disponível em: <http://www.conexaorio.com/biti/otlet/index.htm>. Acesso em: 23 abr. 2013.

Traité de Documentation - Le Livre sur le Livre - Théorie et Pratique. Bruxelles: Mundaneum, Palais Mondial. 1934. 452 p. Disponível em: <http://lib.ugent.be/fulltxt/handle/1854/5612/Traite_de_documentation_ocr.pdf>.

Acesso em: 23 abr. 2013.

PLATAFORMA LATTES. CNPq. Diretório de Grupos de Pesquisa. Brasil. Disponível em: $<$ http://dgp.cnpq.br/buscaoperacional/detalhegrupo.jsp?grupo=0067607UVP2I76>. Acesso em: 16 jun. 2013.

PORTA, Eduard; MONTSERRAT, Rosa M.; MORRAL, Eulália. Sistema de Documentación para Museos. Barcelona: ICOM, Departament de Cultura de la Generalitat de Catalunya, 1982. 84 p.

PREFEITURA DE SÃO PAULO. Portal de Acervos da Secretaria Municipal de Cultura. Acervos artísticos e culturais da Prefeitura de São Paulo. Brasil. Disponível em: $<$ http://www.acervosdacidade.prefeitura.sp.gov.br/PORTALACERVOS>. Acesso em: 15 fev. 2013.

RAMOS FARJARDO, Carmen. Técnicas documentales aplicadas en Museología. In: I CONGRESSO UNIVERSITÁRIO DE CIÊNCIAS DA DOCUMENTAÇÃO. 2009, Madrid. Anais do I Congresso Universitário de Ciências da Documentação: Teoría, Historia y Metodología de la Documentación en España (1975-2000). 2000. Madrid. Disponível em: <http://www.sernageomin.cl/Museo_Geologico/documentos/Cramos.pdf>. Acesso em: 10 fev. 2013.

RAYWARD, William Boyd. The origins of information science and the International Institute of Bibliography/International Federation for Information and Documentation 
(FID). Journal of the American Society for Information Science, New York, v. 48, n. 4, p. 289-300, 1997.

The history and historiography of Information Science: some reflections. Information Processing \& Management, v. 32, n. 1, p. 3-17, 1996.

REIBEL, Daniel B. Registration methods for the Small Museum. 4. ed. EUA: Altamira Press, 2008.187 p.

RIVIĖRE, Georges Henri. La Museología: Curso de Museología/Textos y testimonios. Madrid: Akal, 1993. 553 p.

ROBERTS, D. Andrew; FINK, Eleanor E. Terminology for user-friendly curators. In: Terminology For Museums. United Kingdom: The Museum Documentation Association, Getty Grant Program, 1990. p. 3-6.

ROBERTS, D. Andrew. The Museum Information Profession and CIDOC. In: CONSELHO Internacional de Museus. Study Series - International Committee for Documentation, n³,1996. Disponível em:

http://archives.icom.museum/study_series_pdf/3_ICOM-CIDOC.pdf. Acesso em: 29 jul.2014.

SARACEVIC, Tefko. Ciência da Informação: origem, evolução e relações. Perspectivas em Ciência da Informação, Belo Horizonte, v. 1, n. 1, p. 41-62, jan./jun. 1996.

SECRETARIA DE ESTADO DA CULTURA DE SÃO PAULO. Documentação e Conservação de Acervos Museológicos: Diretrizes. São Paulo: Secretaria de Estado da Cultura de São Paulo/ACAM Portinari, 2010. 112 p.

SIQUEIRA, Graciele Karine. Curso de Museus - MHN: 1932-1978: o perfil acadêmico profissional. Rio de Janeiro, 2009, 178 p. Dissertação (Mestrado em Museologia e Patrimônio) Rio de Janeiro: Escola de Museologia, Universidade Federal do Estado do Rio de Janeiro - UNIRIO, 2009.

SMITH, Johanna Wilhelmina. A interoperabilidade semântica entre os diferentes sistemas de informação no museu. In: MARINGELLI, Isabel Cristina Ayres da Silva; BEVILACQUA, Gabriel Moore Forell (coord.). I Seminário Serviços de Informação em Museus. São Paulo: Pinacoteca do Estado, 2010.

SMIT, Johanna Wilhelmina. Documentação e suas diversas abordagens. In: GRANATO, Marcus; SANTOS, Claudia Penha dos; LOUREIRO, Maria Lúcia Niemeyer Matheus (Orgs.). Documentação em Museus. Rio de Janeiro: MAST, 2008. p. 37-49. (MAST Colloquia; 10).

STRÀNSKY, Zbynek Z. Object-document, or do we know what we are actually collecting?. ICOFOM Study Series, n. 23, p. 47-51, 1994. Disponível em: Disponível em: http://network.icom.museum/icofom/publications/our-publications/. Acesso em: 29 jul.2013. 
SUANO, Marlene. O que é museu. São Paulo: Editora Brasiliense, 1986. 98 p.

TÁLAMO, Maria Fátima Gonçalves Moreira; SMIT, Johanna Wilhelmina. Ciência da Informação: pensamento informacional e integração disciplinar. Brazilian Journal of Information Science, v.1, n.1, p. 33-57, jan./jul 2007. Disponível em: $<$ http://www2.marilia.unesp.br/revistas/index.php/bjis/article/viewFile/30/29>. Acesso em: 18 mar. 2012.

TRIGUEIROS, Florisvaldo dos Santos. Museus e Educação. Rio de Janeiro: Pongetti, 1958. 228 p.

VAN MENSCH, Peter. O objeto de estudo da Museologia. Rio de Janeiro: UNIRIO/Universidade Gama Filho, 1994. (Pretextos Museológicos; 1).

VARINE, Hugues de. Patrimônio e Cidadania. In: SECRETARIA MUNICIPAL DA CULTURA DE PORTO ALEGRE. Museologia social. Porto Alegre: Secretaria Municipal de Cultura, 2000. p. 7-10. 
ANEXO A - Ficha de coleta terminológica.

\begin{tabular}{|c|c|c|c|c|}
\hline Termo Candidato & Sinônimo & Contexto & Fonte & Domínio \\
\hline \multirow[t]{2}{*}{$\begin{array}{l}\text { Documentação } \\
\text { museológica }\end{array}$} & \multirow[t]{2}{*}{$\begin{array}{c}\text { Documentação de } \\
\text { acervos } \\
\text { museológicos }\end{array}$} & $\begin{array}{l}\text { "A documentação de acervos museológicos é o conjunto } \\
\text { de informaçõ̃es sobre cada um dos seus itens e, por } \\
\text { conseguinte, a representação destes por meio da palavra } \\
\text { e da imagem (fotografia). Ao mesmo tempo, é um sistema } \\
\text { de recuperação de informação capaz de transformar, } \\
\text { como anteriormento visto, as coleções dos museus de } \\
\text { fontes de informações em fontes de pesquisa científica ou } \\
\text { em instrumentos de transmissão de conhecimento" }\end{array}$ & $\begin{array}{l}\text { FERREZ, Helena Dodd. } \\
\text { Documentação } \\
\text { museológica: teoria para } \\
\text { uma boa prática. In: IV } \\
\text { Fórum Nordestino de } \\
\text { Museus, 1991, Recife. } \\
\text { Anais do IV Fórum } \\
\text { Nordestino de } \\
\text { Museus. Recife: } \\
\text { IBPC/Fundação } \\
\text { Joaquim Nabuco, } \\
\text { 1991.s/p. }\end{array}$ & Museologia \\
\hline & & $\begin{array}{l}\text { "Em primeiro lugar, a noção de que documentação, mais } \\
\text { do que um conjunto de informações sobre cada item da } \\
\text { coleção, é um sistema composto de partes inter- } \\
\text { relacionadas que formam um todo coerente, unitário, que } \\
\text { intermedia fontes de informação e usuários e se estrutura } \\
\text { em função do objetivo de atender as necessidades de } \\
\text { informação de sua clientela." }\end{array}$ & idem & Idem \\
\hline $\begin{array}{l}\text { Documentação } \\
\text { museográfica }\end{array}$ & documentação & $\begin{array}{l}\text { "Vinculado à pesquisa, o museu é concebido, pois, como } \\
\text { um centro de documentação, onde uma parte de seus } \\
\text { elementos é tridimensional: essa visão permite integrar } \\
\text { todas as coleções, o papel tradicional do museu, em um } \\
\text { programa científico no qual o estudo de objetos é } \\
\text { inseparável de seu ambiente. O termo documentação é } \\
\text { escolhido por sua polissemia, porque inclui tanto a } \\
\text { pesquisa ativa de informações, às vezes a sua produção } \\
\text { pelo prórpio museu e, finalmente, a comunicação, uma } \\
\text { questão que vamos tratar de forma mais ampla " }\end{array}$ & $\begin{array}{l}\text { RIVIĖRE, Georges } \\
\text { Henri. La Museología: } \\
\text { Curso de } \\
\text { Museología/Textos y } \\
\text { testimonios. Madrid: } \\
\text { Akal, 1993. p. } 230 \text {. } \\
\text { Tradução da autora. }\end{array}$ & Museologia \\
\hline
\end{tabular}




\begin{tabular}{|c|c|c|c|}
\hline $\begin{array}{l}\text { Documentação } \\
\text { museográfica }\end{array}$ & $\begin{array}{c}\text { "É o processo de coletar, organizar, guardar, localizar e } \\
\text { dispor documentos, ou a informação contida neles, sobre } \\
\text { os objetos das coleções museológicas" }\end{array}$ & $\begin{array}{l}\text { NOVAES, Lourdes } \\
\text { Rego. Da organização } \\
\text { do patrimônio } \\
\text { museológico: refletindo } \\
\text { sobre documentação } \\
\text { museográfica. In: } \\
\text { SECRETARIA Municipal } \\
\text { da Cultura de Porto } \\
\text { Alegre. Museologia } \\
\text { social. Porto Alegre: } \\
\text { Unidade } \\
\text { Editorial/Secretaria } \\
\text { Municipal de Cultura, } \\
\text { 2000. p.51. }\end{array}$ & Museologia \\
\hline Documentação & $\begin{array}{l}\text { "A documentação do museu compreende as funções de } \\
\text { registro, inventário, controle dos movimentos dos objetos } \\
\text { e catalogação (documentação científica) dos bens } \\
\text { (Alonso, 1999a:159). Em realidade, a documentação } \\
\text { constitui a primeira fase de um processo, que inclui além } \\
\text { disso o recolhimento e análise dos documentos e o } \\
\text { processamento de sua informação e a terceira fase que } \\
\text { consiste no processo de transmissão ou difusão da } \\
\text { informação (Rodriguez, 2002: } 23 \text { ). A tudo isso, há que se } \\
\text { adicionar a gestão do conhecimento" }\end{array}$ & $\begin{array}{l}\text { GUTIERREZ USILLOS, } \\
\text { Andrés. Museología y } \\
\text { documentación: } \\
\text { criterios para la } \\
\text { definición de un } \\
\text { proyecto de } \\
\text { documentación en } \\
\text { museos. Espanha: } \\
\text { Editora Trea, } 2010 . \\
\text { p.129. Tradução da } \\
\text { autora. }\end{array}$ & $\begin{array}{l}\text { Museologia/ } \\
\text { Arquivística }\end{array}$ \\
\hline $\begin{array}{c}\text { Documentação de } \\
\text { museu }\end{array}$ & $\begin{array}{l}\text { "Reunião e registro de informações sobre objetos, suas } \\
\text { histórias e sobre os processos pelos quais eles passam } \\
\text { dentro da instituição. O propósito da documentação é } \\
\text { prestar contas, gerenciar e usar os objetos de modo a } \\
\text { alcançar as metas e objetivos estabelecidos pela } \\
\text { organização colecionadora" }\end{array}$ & $\begin{array}{l}\text { COLLECTIONS TRUST. } \\
\text { Glossary for } \\
\text { SPECTRUM 4.0. } \\
\text { Dawnson, Alex } \\
\text { (Ed.). Reino } \\
\text { Unido, 2011a. p.1. } \\
\text { Disponível em: } \\
\text { <http://www.collectionstr } \\
\text { ust.org.uk/spectrum/glos } \\
\text { sary-for-spectrum-4-0>. } \\
\text { Acesso em: } 27 \text { jun. } \\
2014 \text {. }\end{array}$ & $\begin{array}{l}\text { Gestão de } \\
\text { Coleções }\end{array}$ \\
\hline
\end{tabular}




\begin{tabular}{|c|c|c|c|c|}
\hline $\begin{array}{c}\text { Documentação de } \\
\text { museu }\end{array}$ & & $\begin{array}{l}\text { "Os registros que documentam a criação, o histórico, a } \\
\text { aquisição pelo museu e a história subsequente de todos } \\
\text { os objetos do acervo. Esses registros incluem } \\
\text { documentos de proveniência e origem, documentos de } \\
\text { aquisiçãa, relatórios de conservação, registros de } \\
\text { catalogação, imagens e pesquisas, sendo criados pela } \\
\text { instituição detentora do objeto, proprietários anteriores, } \\
\text { pesquisadores independentes etc. O termo também se } \\
\text { aplica ao processo de coleta dessas informações". }\end{array}$ & $\begin{array}{l}\text { COMITÊ Internacional } \\
\text { de Documentação- } \\
\text { ICOM (CIDOC-ICOM). } \\
\text { International } \\
\text { Guidelines for } \\
\text { Museum Object } \\
\text { Information: The } \\
\text { CIDOC Information } \\
\text { Categories. International } \\
\text { Council of Museums. } \\
\text { 1995. p.24. Disponível } \\
\text { em: } \\
\text { <http://network.icom.mu } \\
\text { seum/cidoc/resources/ci } \\
\text { doc-standards- } \\
\text { guidelines>. Acesso em: } \\
15 \text { abr. 2011. Tradução } \\
\text { da autora. }\end{array}$ & Documentação \\
\hline $\begin{array}{l}\text { Documentação } \\
\text { museológica }\end{array}$ & $\begin{array}{c}\text { Gestão da } \\
\text { informação; gestão } \\
\text { de coleções }\end{array}$ & $\begin{array}{l}\text { "Como já comprovado, a gestão da informação leva em } \\
\text { consideração os serviços de informação que funcionam } \\
\text { em uma organização para a própria organização como } \\
\text { sistema informativo, dado que toda organização recebe, } \\
\text { processa e emite dados e informação, como ocorre com } \\
\text { os museus. [...] No âmbito estadunidense, se tem } \\
\text { compreendido a documentação como uma faceta da } \\
\text { 'gestão das coleções' desde a década de setenta. }\end{array}$ & $\begin{array}{l}\text { MARÍN TORRES, María } \\
\text { Teresa. Historia de la } \\
\text { documentación } \\
\text { museológica: la gestión } \\
\text { de la memoria artística. } \\
\text { Espanha: Editora Trea, } \\
\text { 2002. p. 303-304. } \\
\text { Tradução da autora. }\end{array}$ & Museologia \\
\hline
\end{tabular}




\begin{tabular}{|c|c|c|c|c|}
\hline & & $\begin{array}{c}\text { Também triunfou este termo (collection management) e } \\
\text { conceito no Reino Unido, entendendo que se baseia em } \\
\text { duas operações básicas: a conservação e a } \\
\text { documentação dos objetos e da informação associada a } \\
\text { eles. [...] Portanto, a tendência no âmbito anglo-saxão é a } \\
\text { progressiva consolidação do termo gestão da informação } \\
\text { em vez de documentação, mas compreendida dentro } \\
\text { dessa parcela vertebral do museu que é a gestão das } \\
\text { coleções" }\end{array}$ & & \\
\hline $\begin{array}{c}\text { Documentação de } \\
\text { museus }\end{array}$ & $\begin{array}{c}\text { Documentação em } \\
\text { museus }\end{array}$ & $\begin{array}{l}\text { "Por razões históricas, e outras circunstanciais, entende- } \\
\text { se a documentação de museus como uma série de } \\
\text { procedimentos técnicos para salvaguardar e gerenciar as } \\
\text { coleções sob guarda dos museus. Há concepcções } \\
\text { metodológicas que envolvem a documentação de museus } \\
\text { e subordinam-se a duas perspectivas que respondem por } \\
\text { duas formas de gestão da informação que são distintas } \\
\text { entre si. São elas a perspectiva tecnicista, bastante } \\
\text { apoiada na abordagem norte-americana, e a reflexiva, } \\
\text { mais interpretativa, cunhada por europeus" }\end{array}$ & $\begin{array}{l}\text { CERAVOLO, Suely } \\
\text { Moraes;TÁLAMO, Maria } \\
\text { de Fátima Gonçalves } \\
\text { Moreira. Os museus e a } \\
\text { representação do } \\
\text { conhecimento: uma } \\
\text { retrospectiva sobre a } \\
\text { documentação em } \\
\text { museus e o } \\
\text { processamento da } \\
\text { informação. In: VIII } \\
\text { Enancib - ENCONTRO } \\
\text { NACIONAL DE } \\
\text { PESQUISA EM } \\
\text { CIÊNCIA DA } \\
\text { INFORMAÇÃO, 2007, } \\
\text { Salvador. Anais do VIII } \\
\text { Enancib, Salvador: } \\
\text { PPGCI/UFBA, 2007. } \\
\text { s/p. Disponível em: } \\
\text { <http://www.enancib.pp } \\
\text { gci.ufba.br>. Acesso } \\
\text { em: } 30 \text { abr. } 2010 \text {. }\end{array}$ & $\begin{array}{l}\text { Ciência da } \\
\text { Informação; } \\
\text { Museologia }\end{array}$ \\
\hline
\end{tabular}




\begin{tabular}{|c|c|c|c|c|}
\hline & & $\begin{array}{l}\text { Desse modo, a documentação organiza domínios de } \\
\text { informação instituindo processos e construindo } \\
\text { instrumentos essenciais nos quais os diversos produtores } \\
\text { e usuários de informação possam estabelecer princípios } \\
\text { racionais de preservação, gestão e acesso a essas } \\
\text { informações. A fragmentação dos saberes inerentes à } \\
\text { modernidade ocidental e a heterogeneidade das } \\
\text { produções concretas e simbólicas dos diferentes grupos } \\
\text { sociais são estrategicamente ordenadas e inter- } \\
\text { relacionadas, de forma a atender às demandas dos } \\
\text { diferenciados agentes sociais e institucionais em suas } \\
\text { mais variadas necessidades. }\end{array}$ & $\begin{array}{l}\text { LOUREIRO, José } \\
\text { Mauro Matheus. A } \\
\text { Documentação e suas } \\
\text { diversas abordagens: } \\
\text { esboço acerca da } \\
\text { unidade museológica. } \\
\text { In: GRANATO, Marcus; } \\
\text { SANTOS, Claudia } \\
\text { Penha dos; LOUREIRO, } \\
\text { Maria Lúcia Niemeyer } \\
\text { Matheus (Orgs.). } \\
\text { Documentação em } \\
\text { Museus. Rio de } \\
\text { Janeiro: MAST, 2008. } \\
\text { (MAST Colloquia; 10). p. } \\
\text { 28-29. }\end{array}$ & Idem \\
\hline & & $\begin{array}{c}\text { Documentar é, sobretudo no âmbito museológico, integrar } \\
\text { em conjuntos significativos as tradições, diferenças e } \\
\text { dispersões que caracterizam as ciências, saberes e } \\
\text { discursos contemporâneos em benefício dos mais } \\
\text { diferentes grupos sociais. }\end{array}$ & p. 30. & Idem \\
\hline \multirow[t]{2}{*}{$\begin{array}{c}\text { Documentação } \\
\text { Museológica }\end{array}$} & \multirow[t]{2}{*}{$\begin{array}{c}\text { Gestão } \\
\text { documental; } \\
\text { Documentação de } \\
\text { Gestão } \\
\text { Museológica }\end{array}$} & $\begin{array}{l}\text { "Em um ambiente museológico, o princípio que norteia a } \\
\text { organização das informações é pensado pelo museólogo } \\
\text { documentalista tendo como preocupação principal a } \\
\text { coleta, triagem, organização, controle, armazenagem, } \\
\text { recuperação e divulgação dos registros que possam } \\
\text { servir de base para o desenvolvimento dos trabalhos de } \\
\text { caráter curatorial e sua extroversão através de } \\
\text { exposições relativas às coleções que o museu abriga." }\end{array}$ & $\begin{array}{l}\text { BOTTALLO, Marilúcia. } \\
\text { A Gestão Documental } \\
\text { do Patrimônio } \\
\text { Arqueológico e } \\
\text { Etnográfico. Revista do } \\
\text { Museu de Arqueologia } \\
\text { e Etnologia da USP, } \\
\text { São Paulo, n. 6, 1996. } \\
\text { p. } 291 .\end{array}$ & Museologia \\
\hline & & $\begin{array}{c}\text { "A importância da documentação, considerada como o } \\
\text { método de controle de unidades de informação e dados } \\
{[\ldots . .] "}\end{array}$ & p. 291. & Museologia \\
\hline
\end{tabular}




\begin{tabular}{|c|c|c|c|}
\hline Documentação & $\begin{array}{l}\text { "O acervo museológico, propriamente dito, não será aqui } \\
\text { discutido, mas enfocaremos dois grupos de documentos } \\
\text { gerados nesse contexto: } \\
\text { documentação do acervo, reunindo informação sobre a } \\
\text { origem dos objetos, como estes chegaram ao museu, sua } \\
\text { descrição (materiais, métodos, inscrições etc), pesquisas } \\
\text { feitas para sua contextualização, localização física, } \\
\text { questões patrimoniais ou de direitos autorais, } \\
\text { intervenções que se fizeram necessárias, ações de } \\
\text { preservação etc. Uma potencial fonte de problemas se } \\
\text { encontra na documentação relacionada ao acervo mas } \\
\text { que, inicialmente, se reveste de um caráter mais } \\
\text { 'administrativo' [...] O conjunto de documentos gerados e } \\
\text { percebidos inicialmente em sua condição 'administrativa' } \\
\text { deve ser, num segundo momento, uma vez os trâmites } \\
\text { administrativos realizados e auditados, encaminhado à } \\
\text { documentação do acervo [...] } \\
\text { - a documentação do uso feito do acevo - a montagem de } \\
\text { uma exposição, o empréstimo de uma obra pertencente a } \\
\text { outro museu, a pesquisa sobre determinado artista para } \\
\text { selecionar as obras mais representativas para terminada } \\
\text { exposição, etc geram documentos, igualmente } \\
\text { associados às atividades finalísticas do museu, mas que } \\
\text { não devem ser confundidas com a documentação do } \\
\text { próprio acervo" }\end{array}$ & $\begin{array}{l}\text { SMITH, Johanna } \\
\text { Wilhelmina. A } \\
\text { interoperabilidade } \\
\text { semântica entre os } \\
\text { diferentes sistemas de } \\
\text { informação no museu. } \\
\text { In: MARINGELLI, Isabel } \\
\text { Cristina Ayres da Silva; } \\
\text { BEVILACQUA, Gabriel } \\
\text { Moore Forell (coord.). I } \\
\text { Seminário Serviços de } \\
\text { Informação em } \\
\text { Museus. São Paulo: } \\
\text { Pinacoteca do Estado, } \\
\text { 2010. p.36-37. }\end{array}$ & $\begin{array}{l}\text { Ciência da } \\
\text { Informação }\end{array}$ \\
\hline $\begin{array}{l}\text { Documentação } \\
\text { Museológica }\end{array}$ & $\begin{array}{l}\text { "Sendo assim, a documentação museológica, entendida } \\
\text { como o resgate de informações sobre o objeto, tem como } \\
\text { suporte algumas técnicas e procedimentos retirados da } \\
\text { documentação e da Biblioteconomia, que foram } \\
\text { adequadas aos objetivos relacionados com a questão do } \\
\text { estudo do objeto, sua segurança e controle, como } \\
\text { também, o uso do resgate desta informação para um } \\
\text { discurso museológico - a exposição" }\end{array}$ & $\begin{array}{l}\text { NASCIMENTO, Rosana } \\
\text { Andrade do. } \\
\text { Documentação } \\
\text { Museológica e } \\
\text { Comunicação. } \\
\text { Cadernos de } \\
\text { Museologia, Portugal, } \\
\text { n. } 3,1994 \text {. p. } 35 \text {. }\end{array}$ & Museologia \\
\hline
\end{tabular}

Fonte: Juliana Monteiro, 2013. 